$$
\begin{gathered}
\text { University of Szeged } \\
\text { Faculty of Pharmacy } \\
\text { Department of Pharmacognosy }
\end{gathered}
$$

\title{
PHYTOCHEMICAL, PHARMACOLOGICAL AND TOXICOLOGICAL STUDIES OF ALKALOID- AND SESQUITERPENE LACTONE- CONTAINING MEDICINAL PLANTS
}

Ph.D. Thesis

Tivadar Kiss

Supervisors:

Prof. Judit Hohmann DSc.

Dezső Csupor PhD.

Szeged, Hungary 


\section{LIST OF PUBLICATIONS RELATED TO THE THESIS}

I. Kiss T; Orvos P; Bánsághi Sz; Forgó P; Jedlinszki N; Tálosi L; Hohmann J; Csupor D. Identification of diterpene alkaloids from Aconitum napellus subsp. firmum and GIRK channel activities of some Aconitum alkaloids FITOTERAPIA 2013; 90: 85-93. doi: 10.1016/j.fitote.2013.07.010

II. Kiss T; Szabó A; Oszánci G; Lukács A; Tímár Z; Tiszlavicz L; Csupor D. Repeated-dose toxicity of common ragweed on rats PLOS ONE 2017; 12: e0176818 (18p) doi: 10.1371/journal.pone.0176818

III. Kiss T; Borcsa B; Orvos P; Tálosi L; Hohmann J; Csupor D.

Diterpene lipo-alkaloids with selective activities on cardiac $\mathrm{K}^{+}$channels PLANTA MEDICA 2017; accepted doi: $10.1055 / \mathrm{s}-0043-109556$

IV. Kiss T; Mácsai L; Csupor D; Datki Zs. In vivo screening of diterpene alkaloids using bdelloid rotifer assays Acta Biologica Hungarica 2017; 68 (4) accepted

V. $\quad$ Kiss T; Cank K; Orbán-Gyapai O; Liktor-Busa E; Rutkovska S; Zomborszki Z; Pučka I; Németh A; Csupor D.

Phytochemical and pharmacological investigation of Spiraea chamaedryfolia-A contribution to the chemotaxonomy of Spiraea genus BMC Research Notes 2017; submitted 


\section{TABLE OF CONTENTS}

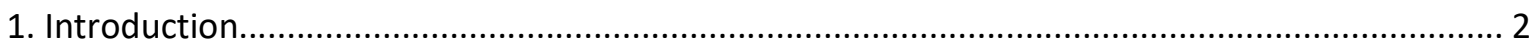

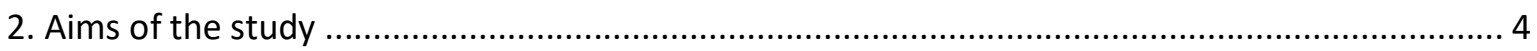

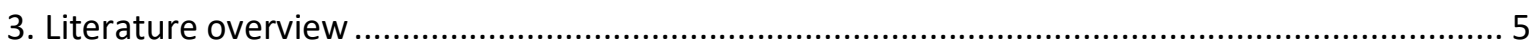

3.1. Botany of the investigated species ...................................................................... 5

3.1.1. Botany of Aconitum species ........................................................................... 5

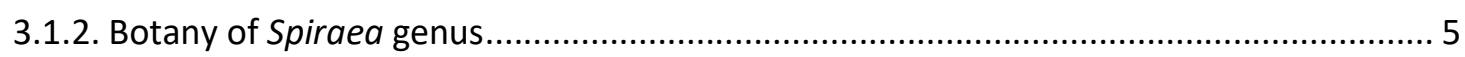

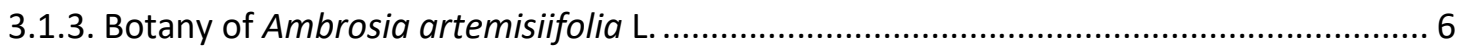

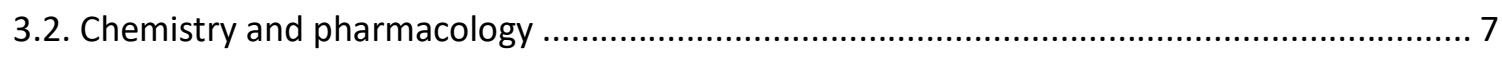

3.2.1. Recent advances in phytochemistry and pharmacology of Aconitum species ............... 7

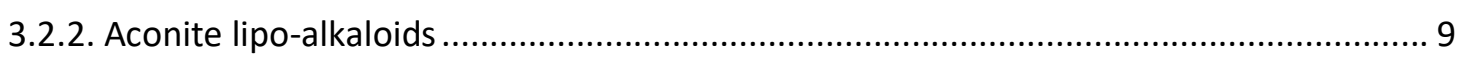

3.2.3. Activity of aconite diterpene alkaloids on $\mathrm{Na}^{+}$and $\mathrm{K}^{+}$channels ................................. 10

3.2.4. Phytochemistry and pharmacology of Spiraea genus ........................................... 12

3.2.5. Phytochemistry and pharmacology of Ambrosia artemisiifolia ............................... 14

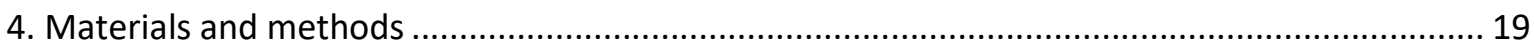

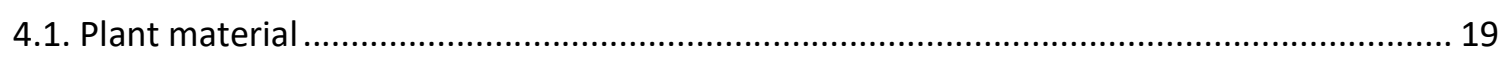

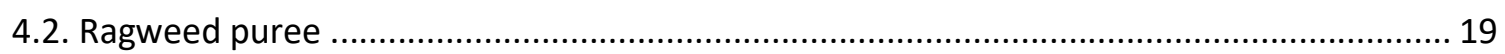

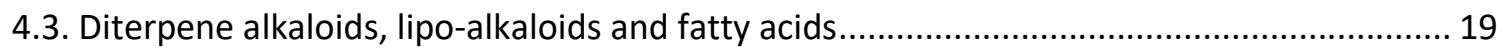

4.4. Purification and isolation of the compounds ....................................................... 20

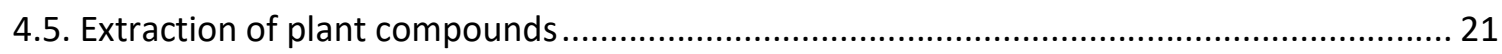

4.5.1. Preparation and phytochemical screening of $A$. napellus subsp. firmum extracts....... 21

4.5.2. Preparation of crude alkaloid extract from Aconitum napellus subsp. firmum ............ 22

4.5.3. Preparation of Spiraea extracts for alkaloid-content screening .............................. 22

4.5.3. Preparation of Spiraea chamaedryfolia fractions ................................................ 22

4.6. Identification and structure elucidation of compounds ........................................... 23

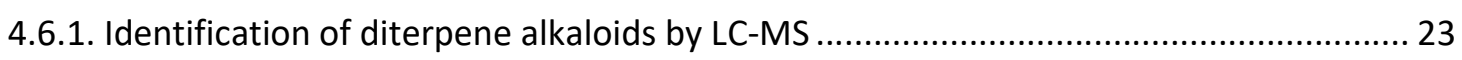

4.6.2. Sesquiterpene lactone content identification in common ragweed puree .................. 23

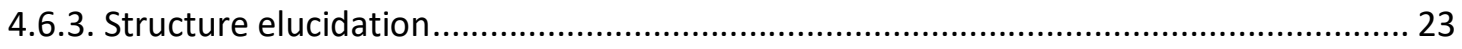

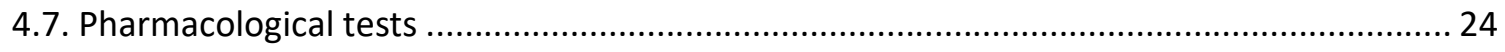

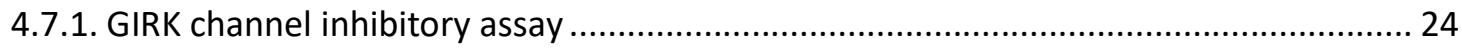

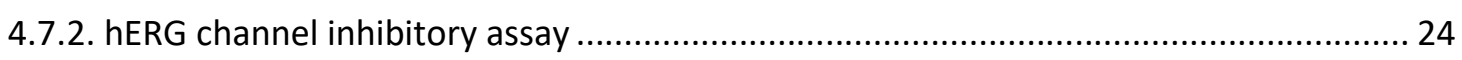

4.7.3. Screening for antibacterial activity ............................................................... 24

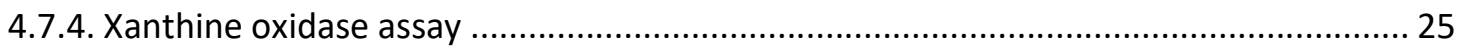

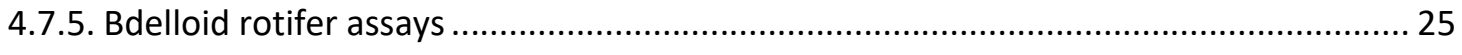

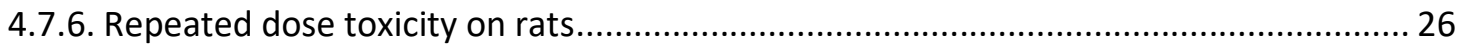

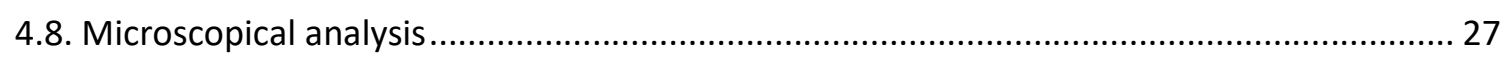

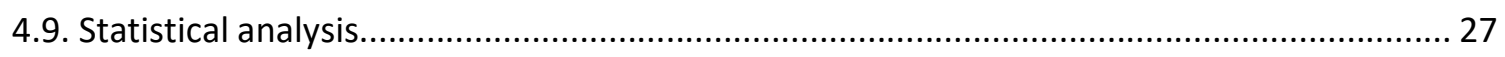

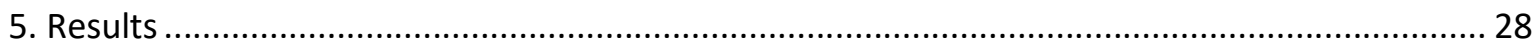




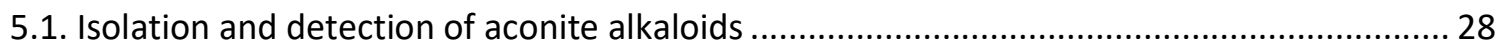

5.2. Investigation of Spiraea species for alkaloid content .......................................................... 31

5.3. Pharmacological activity of aconite alkaloids .................................................................. 33

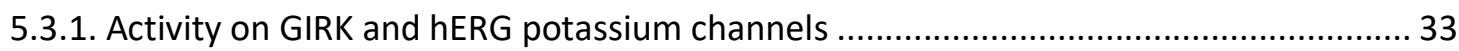

5.3.2. Activity of aconite alkaloids in bdelloid viability assays ................................................ 37

5.4. Pharmacological activity of Spiraea chamaedryfolia extracts ............................................. 38

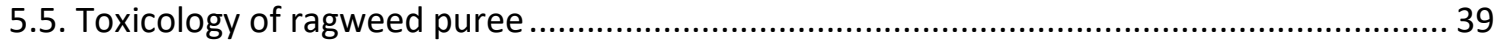

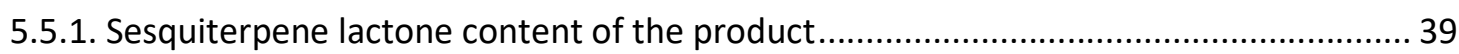

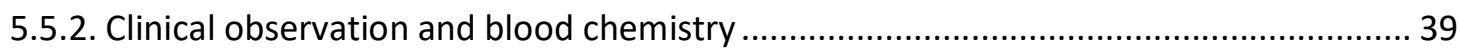

5.5.3. General toxicological parameters ............................................................................. 40

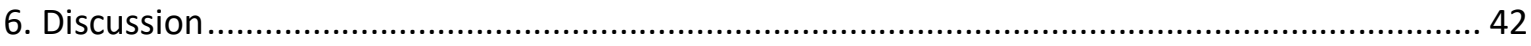

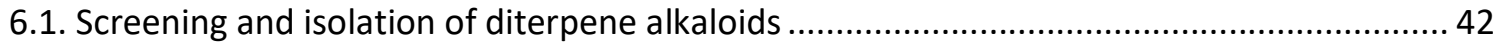

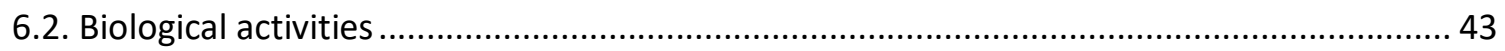

6.2.1. Effects of aconite alkaloids on GIRK and hERG channels .......................................... 43

6.2.2. Biological activity of Spiraea chamaedryfolia extracts .................................................. 46

6.2.3. Toxicity of diterpene alkaloids on bdelloid rotifers ....................................................... 46

6.2.4. Toxicological evaluation of common ragweed................................................................. 47

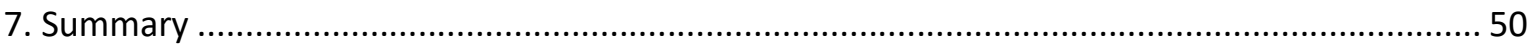

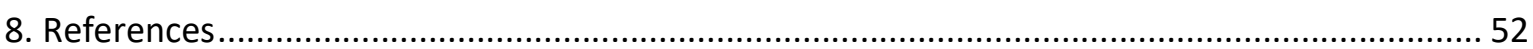

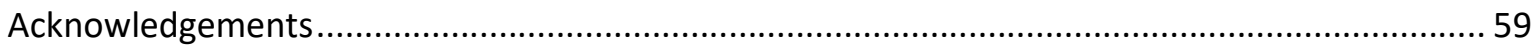

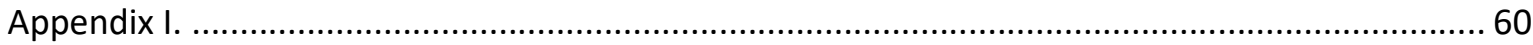

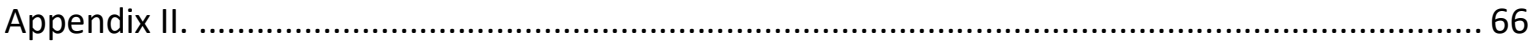




\section{AbBreviations}

\begin{tabular}{|c|c|}
\hline 1D & one-dimensional \\
\hline 2D & two-dimensional \\
\hline Ac & acetyl \\
\hline $\mathrm{AcNi}$ & acetonitrile \\
\hline ACON & aconitine \\
\hline ALP & alkaline phosphatase \\
\hline ALT & alanine aminotransferase \\
\hline BAE-11TRI & 14-BzA-8-O-eicosa-11Z,14Z,17Z-trienoate \\
\hline BAE-DI & 14-BzA-8-O-eicosa-11Z,14Z-dienoate \\
\hline BAE-PENT & 14-BzA-8-O-eicosa-5Z,8Z,11Z,14Z,17Z-pentaenoate \\
\hline BAE-TETR & 14-BzA-8-O-eicosa-5Z,8Z,11Z,14Z-tetraenoate \\
\hline $\mathrm{BAL}$ & 14-BzA-8-O-laurate \\
\hline BAP & 14-BzA-8-O-palmitate \\
\hline BAPO & 14-BzA-8-O-palmitoleate \\
\hline BAS & 14-BzA-8-O-stearate \\
\hline BEA-8TRI & 14-BzA-8-O-eicosa-8Z,11Z,14Z-trienoate \\
\hline $\mathrm{BSI}$ & body size index \\
\hline $\mathrm{Bz}$ & benzoyl \\
\hline BzA & benzoyl aconine \\
\hline $\mathrm{CC}$ & open-column chromatography \\
\hline $\mathrm{CH}_{2} \mathrm{Cl}_{2}$ & dichloromethane \\
\hline CON & control \\
\hline COSY & correlated spectroscopy \\
\hline $\operatorname{cox}$ & cyclooxygenase \\
\hline CPC & centrifugal planar chromatography \\
\hline CRC & cellular reduction capacity \\
\hline DA & diterpene alkaloid \\
\hline E-11TRI & eicosa-11Z,14Z,17Z-trienoic acid \\
\hline E-8TRI & eicosa-8Z,11Z,14Z-trienoic acid \\
\hline $\mathrm{ED}_{50}$ & median effective dose \\
\hline E-DI & eicosa-11Z,14Z-dienoic acid \\
\hline E-EN & eicosa-11Z-enoic acid \\
\hline E-PENT & eicosa-5Z,8Z,11Z,14Z,17Z-pentaenoic acid \\
\hline E-TETR & eicosa-5Z,8Z,11Z,14Z-tetraenoic acid \\
\hline EtOAc & ethyl acetate \\
\hline $\mathrm{EtOH}$ & ethanol \\
\hline FA & fatty acid \\
\hline g-BALL & 14-BzA-8-O- $\nu$-linolenate \\
\hline GFC & gel-filtration chromatography \\
\hline GIRK & G protein-coupled inwardly-rectifying potassium channel \\
\hline g-LIN & 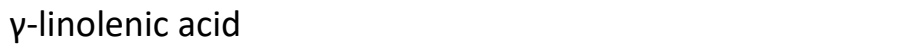 \\
\hline HD & high dose \\
\hline hERG & human ether-à-go-go-related gene \\
\hline $\mathrm{HMBC}$ & heteronuclear multiple-bond correlation \\
\hline HSQC & heteronuclear single-quantum correlation \\
\hline iv. & intravenous \\
\hline JMOD & $J$-modulated spin-echo experiment \\
\hline LA & lipo-alkaloid \\
\hline LC & liquid chromatography \\
\hline LD & low dose \\
\hline
\end{tabular}




$\begin{array}{ll}\text { LD }_{50} & \text { median lethal dose } \\ \text { LOX } & \text { lipoxygenase } \\ \text { MCF } & \text { mastax contraction frequency assay } \\ \text { MeOH } & \text { methanol } \\ \text { MRM } & \text { multiple reaction monitoring } \\ \text { MS } & \text { mass spectrometry } \\ \text { NF-KB } & \text { nuclear factor kappa-light-chain-enhancer of activated B cells } \\ \text { NOESY } & \text { nuclear Overhauser effect spectroscopy } \\ \text { PALO: } & \text { palmitoleic acid } \\ \text { PLC } & \text { preparative layer chromatography } \\ \text { SD } & \text { standard deviation } \\ \text { SEM } & \text { standard error of means } \\ \text { SiO } & \text { silica gel } \\ \text { SONG } & \text { songorine } \\ \text { SPE } & \text { solid phase extraction } \\ \text { SUbSp } & \text { subspecies } \\ \text { Syn. } & \text { synonym } \\ \text { TCM } & \text { Traditional Chinese Medicine } \\ \text { TLC } & \text { thin-layer chromatography } \\ \text { TSL } & \text { toxicity and survival lifespan } \\ \text { XO } & \text { xanthine oxidase } \\ \delta & \text { chemical shift }\end{array}$




\section{INTRODUCTION}

The kingdoms of plants, animals and fungi are rich and important sources of natural products. For centuries, various diseases have been treated with living organisms in raw or processed form. In modern medicine, drugs and natural products are important raw materials for the pharmaceutical industry and serve as lead compounds in the research and development of medicines. Taking into consideration the high ratio of pharmacons of natural origin to synthetic compounds [1], it is indeed the New Golden Age of natural product discovery [2].

Traditionally applied medicinal plants are of great importance. In case of effectiveness and safety, the authorisation often relies on long-term medicinal use. However, the pharmacovigilance data of medicinal herbs reveal a need for continuous re-evaluation [3]. Safety issues might be caused by minor compounds in drugs, which are exerting side effects after long-term, sometimes decades, of application. In many cases, the health risks related to the application of a medicinal plant remains hidden for centuries and only modern chemical and pharmacological studies are able to reveal the real toxicological character of traditionally applied herbs. Till recently, the per os application of Symphytum officinale roots was considered as safe in case of arthritis, thrombophlebitis, gout and in the treatment of diarrhoea. After recognising its hepatotoxic pyrrolizidine alkaloid-content, the application of this drug was limited [4]. Chelidonium majus L. is a popular plant with a wide spectrum of biological activities. Extracts, tincture and other remedies are in use, often applied internally. The per os application of these preparations has to be revised, since there might be a risk of cardiac side effects due to the activity of some extracts on hERG channels [5].

Modern approaches of phytochemistry and pharmacology might lead to new breakthroughs in drug research. The better understanding of traditional application and processing of medicinal herbs resulted in the discovery of novel mechanisms of action and new active constituents of these plants. Aconitum species are good examples how new results can open new ways in the research of traditionally used plants. Several highly toxic Aconitum species have been applied in Traditional Chinese Medicine. The raw herbal substances were cautiously processed in order to reduce their toxicity. Although neither the exact chemistry of these drugs, nor the pharmacological mechanisms have been thoroughly clarified, aconite drugs were among the most popular TCM medicines. Later, the chemical analysis of raw plant materials and processed drugs made it possible to identify their biological active compounds and their change during processing. In the raw plant material, diterpene alkaloids were identified. These compounds, mainly aconitine (18), are highly toxic. Furthermore, the toxicity of these compounds are depending on the number of ester groups present in the molecule, thus the most toxic ones are diester diterpene alkaloids 
and monoester diterpene alkaloids are less toxic, while the least toxic are those without an ester group. Lipo-alkaloids are diterpene alkaloids esterified with long-chain fatty acids, usually at position C-8. These lipo-alkaloids are minor compounds in unprocessed drugs, and they are proved to be far less toxic than diterpene alkaloids. During processing of the herbal substance, the amount of tri- and diester alkaloids is decreasing, while the amount of unesterified diterpene alkaloids and lipo-alkaloids is increasing [6]. The understanding of these chemical changes [7] and identification of lipo-alkaloids as biologically active constituents in processed aconite drugs triggered experiments to semisynthesize new compounds and investigate their pharmacological effects [8]. Even though the well-known Aconitum species were removed from the Western Pharmacopoeias, natural products of aconite origin are promising as anti-inflammatory or antiarrhythmic pharmacons. The analysis of structure-activity relationships of diterpene alkaloids led to the development of new diterpene alkaloid-based medicines and the discovery of promising pharmacones [9].

In the recent years, medicinal plants are typically marketed as food supplements. Several products contain herbs that have not been extensively used before, and there are no pharmacological, toxicological and phytochemical data available to serve as basis for the assessment of their effectiveness, safety and quality. Plants that have not been consumed to a significant degree by humans in the European Union prior to 1997 are considered as novel food [10]. One example for novel food (though unauthorised) is Ambrosia artemisiifolia, which has become quite popular as a medicinal plant in the recent years in Hungary. However, this plant has not been consumed or used as a medicinal herb before, hence its toxicological profile is unexplored and the risk related to its consumption is unknown. 


\section{AIMS OF THE STUDY}

In 2000, the research group of the Department of Pharmacognosy (University of Szeged) started a screening programme for isolation and identification of Ranunculaceae alkaloids in order to find new biologically active compounds and the rational explanations of the folk medicinal use of the toxic species. Later, the scope of the experiments was extended to the safety pharmacology, toxicology and chemistry of traditional and newly discovered medicinal plants.

According to this comprehensive approach, the aim of the present work was the chemical, pharmacological and toxicological investigation of diterpene alkaloid-containing traditional medicinal plants and one, only recently applied species, to reveal the dangers of their use and to identify their potential role in modern medicine.

In order to achieve the aims, the main tasks were:

- Review the literature of the Aconitum, Spiraea genera and Ambrosia artemisiifolia, from aspects of the chemistry and pharmacological properties of the plants.

- Diterpene alkaloid extraction and identification from Aconitum napellus subsp. firmum.

- Investigation of the activity of Ranunculaceae diterpene alkaloids and semisynthetic lipoalkaloids on GIRK and hERG channels.

- Evaluation of antiarrhythmic potential of Ranunculaceae diterpene alkaloids.

- In vivo toxicological evaluation of diterpene alkaloids using bdelloid rotifer assays.

- Extraction of Spiraea species with various alkaloid extraction methods for alkaloid-content screening, and investigation of the antibacterial and xanthine oxidase inhibitory activity.

- In vivo toxicological examination of common ragweed on rats. 


\section{LITERATURE OVERVIEW}

\subsection{Botany of the investigated species}

\subsubsection{Botany of Aconitum species}

The Aconitum genus belongs to Ranunculaceae family, order of Ranunculales, superorder of Ranunculanae, subclass of Ranunculidae, Dicotyledonopsida class, Angiospermatophytina subdivision, Spermatophyta division. The phylogeny of this genus is extremely complex, due to the allopatric and parapatric speciation. The genus, comprised of 300 species, is divided into three subgenera: only one species is rendered to Gymnaconitum (Stapf.) subgenus; Lycoctonum (DC) Peterm. contains around 50 species; the largest subgenus is Aconitum with 250 species [11]. Since molecular phylogenetic studies suggest that the hotspot of Aconitum species speciation was located to Himalaya Mountains, it is reasonable that vast majority of Aconitum species can be found in Asia (cca. 220) [12]. According to Flora Europaea only 7 species are part of the European flora, from which 5 species are native to the Carpathian Basin [13].

Aconitum napellus subsp. firmum Rchb. Gáyer (syn. Aconitum firmum Rchb.) is a perennial herb native to Carpathian Basin, distributed from Czech Republic to East Carpathians in Transylvania. The plant is $50-150 \mathrm{~cm}$ tall. The dark-green, alternate leaves are palmate, divided into 5-7 segments. The inflorescence is few-flowered, with 20-35 mm high, blue and hairy flowers.

\subsubsection{Botany of Spiraea genus}

The Spiraea genus, comprising of approximately 100 species, belongs to Rosaceae family, order of Rosales, subclass of Rosidae, Magnoliopsida class, Magnoliphyta subdivision, Spermatophyta division. [14]. Spiraea species are widely distributed all over the world. The centre of the distribution is Asia [15], while in Europe 20 species are part of the Flora [16]. The genus was further divided according to the morphology of the inflorescences into Spiraria, Calospira and Chamaedryon groups. Since the monophyletic origin of these groups is not supported by the latest molecular phylogeny, the classical division has to be revised [17].

Spiraea species are perennial, multi-stemmed, deciduous, spreading and upright featured shrubs with corymb inflorescence. Spiraea creanata L. has reddish-brown branches and grows $1 \mathrm{~m}$ tall. The greyish-green leaves are lanceolate to obovate and the $20 \mathrm{~mm}$ wide inflorescence comprises of 10 white flowers [18]. S. salicifolia L. is 1.5-2.0 m high shrub with non-spreading branches, and alternate lanceolate leaves. Inflorescences are 5-12 cm high conical panicles with pink or rose flowers. S. nipponica Maxim. is a 1.2-2.5 m tall shrub, with simple leaves with serrated leaf tips. The inflorescence is umbel-like raceme, with white flowers. S. $x$ vanhouttei, 1.8-2.5 $\mathrm{m}$ high 
shrub with dark blue-green coloured, simple small leaves has inflorescences with 3-6 cm in diameter, composed of white flowers. 2-5 cm long lanceolate leaves and pink conical panicle inflorescences are characteristic for S. x billardii hort. ex K. Koch. S. media Schmidt is 1.0-1.5 m tall shrub with lanceolate to oblanceolate leaves. The small, white flowers can be found in umbel-like inflorescences. S. chamaedryfolia L. is reaching 1.0-1.5 m height. The leaves are simple or lanceolate with toothed edges. The inflorescence is consisted of 6-9 $\mathrm{mm}$ wide white flowers growing in spikelike clusters at the ends of the branches $[16,19,20]$. Because of their decorative inflorescence, several species are used as ornamental plants which might easily turn into invasive [21].

\subsubsection{Botany of Ambrosia artemisiifolia L.}

Ambrosia artemisiifolia L. is an annual herb, belonging to Asteraceae family, order of Asterales, subclass Asteroideae, Dicotyledonopsida class, Angiospermatophytina subdivision, Spermatophyta division. A. artemisiifolia is an erect $20-200 \mathrm{~cm}$ tall branchy herb, with densely hairy stem. The alternate leaves morphology shows great variability. The blades are lanceolate or elliptic, pinnated with 2-3 oblong-lanceolate, toothed or lobed segments on each side. Flowers are arranged in capitula [22].

The phylogenesis of the Ambrosia genus took place at the Sonoran Desert (USA). Later the genus radiated outwards to the territories of North America and Mexico which is now considered as a native region of the $A$. artemisiifolia $[23,24]$. The first seeds arrived to Europe around 1860 probably with clover seed grains [25]. In the 1930's it was introduced to China $[26,27]$. Nowadays it is widespread in Europe (Hungary, former Yugoslavian countries, France, Switzerland, Germany and Russia), Japan, South Korea, Australia, New Zealand, Central and South America [28]. The fast spreading of $A$. artemisiifolia can be explained by its wide ecological niche, which meets the environmental conditions of the aforementioned territories. This fact makes common ragweed one of the most invasive species in the world $[29,30]$. There is some evidence that the infection of new territories might speed up as a consequence of global warming [31-34] and the great genetic variability of ragweed. 


\subsection{Chemistry and pharmacology}

\subsubsection{Recent advances in phytochemistry and pharmacology of Aconitum species ${ }^{1}$}

Aconitum species have been part of the Asian and Indian Materia Medica for centuries. Today, two species, namely A. carmichaelii and A. kusnezoffii, are part of the Chinese Pharmacopeia [35]. In the Ayurvedic Pharmacopoeia of India A. heterophyllum [36] is official. Beside these species, many others are still in use, as important traditional medicines [37].

The most characteristic compounds of Aconitum species are diterpene alkaloids. These complex and highly diverse compounds can be classified according to the basic skeleton's carbon atom number $\left(\mathrm{C}_{18}\right.$ - bisnorditerpene alkaloids, $\mathrm{C}_{19}$ - norditerpene alkaloids, $\mathrm{C}_{20}$ - diterpene alkaloids) and by their ester groups (mono-, di- and triesters). Diterpene alkaloids, esterified with fatty acids, are lipo-alkaloids, which are present as minor compounds in the unprocessed drugs, however, interestingly during processing (usually boiling) their amount is increasing.

In the last 5 years, the extensive phytochemical research, focusing on the alkaloid content of Aconitum species have resulted in the identification of 70 new compounds (Table 1.).

Table 1. New alkaloids from Aconitum species

( $C_{18}$ : bisnor-, $C_{19}$ : nor-, $C_{20}$ : diterpene alkaloids, $A$ : amide alkaloids, AP: aporphine type alkaloid)

\begin{tabular}{|c|c|c|c|}
\hline Type & Compound & Species & Ref. \\
\hline A & aconitamide (23) & A. carmichaelii & [38] \\
\hline A & vaginatunine $A(24)$ & A. vaginatum & [39] \\
\hline A & vaginatunine $B(25)$ & A. vaginatum & [39] \\
\hline AP & $\begin{array}{l}\text { 6-formyl-1,2,9,10-tetramethoxy-6 } \alpha, 7- \\
\text { dehydroaporphine (47) }\end{array}$ & A. carmiachelii & [40] \\
\hline $\mathrm{C}_{18}$ & kirinenine $\mathrm{A}(48)$ & A. kirinense & [41] \\
\hline $\mathrm{C}_{18}$ & ranaconidine (49) & A. sinomontanum & [42] \\
\hline $\mathrm{C}_{18}$ & sinomontadine (50) & A. sinomontanum & [43] \\
\hline $\mathrm{C}_{18}$ & sinomontadine N (51) & A. sinomontanum & [43] \\
\hline $\mathrm{C}_{18}$ & vaginatunine $\mathrm{C}(52)$ & A. vaginatum & [39] \\
\hline $\mathrm{C}_{18}$ & weisaconitine A (53) & A. weixiense & [44] \\
\hline $\mathrm{C}_{18}$ & weisaconitine B (54) & A. carmiachelii & [44] \\
\hline $\mathrm{C}_{18}$ & weisaconitine C (55) & A. carmiachelii & [44] \\
\hline $\mathrm{C}_{18}$ & weisaconitine D (56) & A. carmiachelii & [44] \\
\hline $\mathrm{C}_{19}$ & 14-acetoxy-8-O-methylsachaconitine (57) & A. forrestii & [45] \\
\hline $\mathrm{C}_{19}$ & 14-acetoxyscaconine (58) & A. forrestii & [45] \\
\hline $\mathrm{C}_{19}$ & 14-anisoylliljestrandisine (59) & A. tsaii & [46] \\
\hline $\mathrm{C}_{19}$ & 14-benzoylliljestrandisine (60) & A. tsaii & [46] \\
\hline $\mathrm{C}_{19}$ & $\begin{array}{l}\text { 14 } \alpha \text {-benzoyloxy- } 8 \beta \text {-butoxy- } 3 \alpha, 13 \beta, 15 \alpha \text {-trihydroxy- } \\
1 \alpha, 6 \alpha, 16 \beta, 18 \text {-tetramethoxy- } N \text {-methylaconitane } \\
(61)\end{array}$ & A. carmichaelii & [47] \\
\hline $\mathrm{C}_{19}$ & 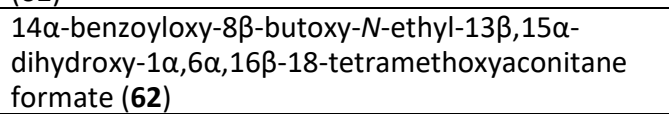 & A. carmichaelii & [47] \\
\hline
\end{tabular}

${ }^{1}$ Csupor (2007) [305] and Borcsa (2014) [85] provided in their PhD theses detailed review about the chemistry of Aconitum species, diterpene alkaloids and lipo-alkaloids. Therefore in this chapter the studies from 2013 have been reviewed. 


\begin{tabular}{|c|c|c|c|}
\hline Type & Compound & Species & Ref. \\
\hline $\mathrm{C}_{19}$ & 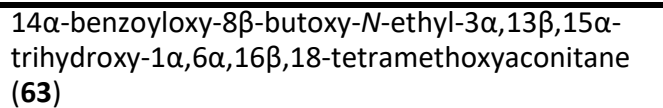 & A. carmichaelii & [47] \\
\hline $\mathrm{C}_{19}$ & $\begin{array}{l}14 \alpha \text {-benzoyloxy- } N \text {-ethyl-15 } \alpha \text {-hydroxy- } \\
1 \alpha, 6 \alpha, 8 \beta, 16 \beta, 18 \text {-pentamethoxyaconitane formate } \\
(64)\end{array}$ & A. carmichaelii & [47] \\
\hline $\mathrm{C}_{19}$ & 8-O-ethylcammaconine $(65)$ & A. forrestii & [45] \\
\hline $\mathrm{C}_{19}$ & $\begin{array}{l}8 \beta, 14 \alpha \text {-dibenzoyloxy- } N \text {-ethyl-13 } \beta, 15 \alpha \text {-dihydroxy- } \\
1 \alpha, 6 \alpha, 16 \beta, 18 \text {-tetramethoxyaconitane }(66)\end{array}$ & A. carmiachaelii & [47] \\
\hline $\mathrm{C}_{19}$ & carmichaenine A (67) & A. carmichaelii & [48] \\
\hline $\mathrm{C}_{19}$ & carmichaenine B (68) & A. carmichaelii & [48] \\
\hline $\mathrm{C}_{19}$ & carmichaenine C (69) & A. carmichaelii & [48] \\
\hline$C_{19}$ & carmichaenine D (70) & A. carmichaelii & [48] \\
\hline $\mathrm{C}_{19}$ & carmichaenine E (71) & A. carmichaelii & [48] \\
\hline $\mathrm{C}_{19}$ & ducloudine $F(\mathbf{7 2})$ & A. duclouxii & [49] \\
\hline $\mathrm{C}_{19}$ & ducloudine C (73) & A. duclouxii & [50] \\
\hline$C_{19}$ & ducloudine D (74) & A. duclouxii & [50] \\
\hline$C_{19}$ & ducloudine E (75) & A. duclouxii & [50] \\
\hline $\mathrm{C}_{19}$ & nagaconitine $\mathrm{A}(\mathbf{7 6})$ & A. nagarum var. heterotrichum & [51] \\
\hline $\mathrm{C}_{19}$ & nagaconitine B (77) & A. nagarum var. heterotrichum & [51] \\
\hline $\mathrm{C}_{19}$ & nagaconitine C (78) & A. nagarum var. heterotrichum & [51] \\
\hline$C_{19}$ & nagaconitine D (79) & A. nagarum var. heterotrichum & [51] \\
\hline $\mathrm{C}_{19}$ & sinchiangensine $A(\mathbf{8 0})$ & A. sinchiangense & [52] \\
\hline $\mathrm{C}_{19}$ & stapfianine $A(81)$ & A. stapfianum & [53] \\
\hline $\mathrm{C}_{19}$ & swatinine-A (82) & A. leave & [54] \\
\hline $\mathrm{C}_{19}$ & swatinine-B (83) & A. laeve & [54] \\
\hline $\mathrm{C}_{19}$ & szechenyianine A (84) & A. szechenyianum & [55] \\
\hline $\mathrm{C}_{19}$ & szechenyianine B (85) & A. szechenyianum & [55] \\
\hline $\mathrm{C}_{19}$ & szechenyianine C (86) & A. szechenyianum & [55] \\
\hline $\mathrm{C}_{19}$ & taipeinine $\mathrm{A}(\mathbf{8 7})$ & A. taipeicum & [56] \\
\hline $\mathrm{C}_{19}$ & taipeinine B (88) & A. taipeicum & [56] \\
\hline $\mathrm{C}_{19}$ & taipeinine C (89) & A. taipeicum & [56] \\
\hline $\mathrm{C}_{19}$ & vilmorine $A(90)$ & A. vilmorinianum & [57] \\
\hline $\mathrm{C}_{19}$ & vilmorine B (91) & A. vilmorinianum & [57] \\
\hline $\mathrm{C}_{19}$ & vilmorine C (92) & A. vilmorinianum & [57] \\
\hline $\mathrm{C}_{19}$ & vilmorine D (93) & A. vilmorinianum & [57] \\
\hline $\mathrm{C}_{19}$ & vilmotenitine $A(94)$ & A. vilmorinianum & [58] \\
\hline $\mathrm{C}_{19}$ & vilmotenitine B (95) & A. vilmorinianum & [58] \\
\hline $\mathrm{C}_{19}$ & vilmotenitine C (96) & A. vilmorinianum & [58] \\
\hline $\mathrm{C}_{20}$ & $\begin{array}{l}\text { 1,11-diacetoxy-2,13-dibenzoyloxy-7-hydroxy-15- } \\
\text { isobutanoyloxy- } N \text {-methyl- } N, 19 \text {-secohetisan-19-al } \\
\text { (97) }\end{array}$ & A. carmichaelii & [59] \\
\hline $\mathrm{C}_{20}$ & aconicarmicharcutinium A hydroxide (98) & A. carmichaelii & {$[60]$} \\
\hline $\mathrm{C}_{20}$ & bullatine $\mathrm{H}(99)$ & A. brachypodum & [61] \\
\hline $\mathrm{C}_{20}$ & carmichaedine (100) & A. carmichaelii & [62] \\
\hline $\mathrm{C}_{20}$ & carmichaeline A (101) & A. carmichaelii & [63] \\
\hline $\mathrm{C}_{20}$ & Guan-Fu base J (102) & A. koreanum & [64] \\
\hline $\mathrm{C}_{20}$ & Guan-Fu base N (103) & A. koreanum & [64] \\
\hline$C_{20}$ & pubesine (104) & A. soongaricum var. pubescens & [65] \\
\hline $\mathrm{C}_{20}$ & sinomontanidine A (105) & A. sinomontanum & [66] \\
\hline $\mathrm{C}_{20}$ & sinomontanidine B (106) & A. sinomontanum & {$[66]$} \\
\hline $\mathrm{C}_{20}$ & trichocarpisine A (107) & A. tanguticum var. trichocarpum & [67] \\
\hline $\mathrm{C}_{20}$ & trichocarpisine B (108) & A. tanguticum var. trichocarpum & [67] \\
\hline $\mathrm{C}_{20}$ & trichocarpisine C (109) & A. tanguticum var. trichocarpum & [67] \\
\hline $\mathrm{C}_{20}$ & vilmorrianine E (110) & A. vilmorianum & [68] \\
\hline $\mathrm{C}_{20}$ & vilmorrianine $\mathrm{F}$ (111) & A. vilmorianum & [68] \\
\hline$C_{20}$ & vilmorrianine G (112) & A. vilmorianum & [68] \\
\hline
\end{tabular}


Pharmacological investigations were performed with Aconitum extracts and with pure compounds, as well. Noteworthy and promising results have been reported on selective cytotoxicity, antiproliferative and antitumor activity of diterpene-alkaloids. Aconitine (18) exerted selective cytotoxicity on Miacapa-2 and PANC-1 pancreatic cell lines in vitro. Moreover in xenograft mouse model it suppressed pancreatic cancer in vivo by inhibition of NF-KB [69]. Nagaconitine C (78) and nagaconitine $D$ (79) exerted selective cytotoxic activity on human ovarian cancer line (SK-OV-3) [51]. Taipeinine A (87) suppressed HL-60 cells, thus it might be worthy for investigation for antileukemic effect [56]. The polysaccharide from $A$. koreanum (100 mg/kg dose) suppressed the pituitary tumor transforming gene in rats, and in vitro it was effective on $\mathrm{H} 22$ cell lines [70].

Analgesic activity of diterpene alkaloids was observed in vivo. These compounds exerted effect comparable to the sodium metamizole during the painful reaction induced by acetic acid [71]. The processed extract of $A$. jaulense exerted significant anti-allodynic effect in rats in case of intrathecal administration [72]. Local anaesthetic effect is explained by diterpene alkaloids' activity on voltage-gated sodium channels [73].

Anti-inflammatory effect was reported for diterpene alkaloids with various skeletons. 1,11diacetoxy-2,13-dibenzoyloxy-7-hydroxy-15-isobutanoyloxy- $N$-methyl- $N, 19$-secohetisan-19-al inhibited the COX-2 enzyme in vitro [59]. Napelline (32), songorine (30) and mesaconitine (113) exerted significant anti-inflammatory effect, compared to diclofenac, in histamine and carrageenan-induced acute inflammation in mice [74], while swatinine-B (83) and neoline (15) showed to be more effective than indomethacin [54]. RG-II type polysaccharides isolated from $A$. koreanum alleviated the lipopolysaccharide-induced inflammation by inhibiting NF-KB [75].

Songorine (30) was examined in Vogel's test on mice, where showed to be potent anxiolytic [76]. Further study revealed that songorine (30) does not have sedative effect [77].

\subsubsection{Aconite lipo-alkaloids}

Lipo-alkaloids have been isolated by Kitagawa et al. for the first time in 1982, and were identified as esters of long-chain fatty acids and diterpene alkaloids [78]. Since then a series of lipo-alkaloids have been identified. 173 compounds were reported in a comprehensive review by Borcsa et al. [79], all were $C_{19}$ diester diterpene alkaloids esterified with long-chain fatty acid in position C-8, and occasionally in position C-3 in case of dilipo-alkaloids [80]. The esterifying fatty acids vary in carbon atom number of the chain and the grade of saturation. In the last five years, new lipo-alkaloids have been identified, mainly by means of LC-MS, and around 100 potentially new lipo-alkaloids are predicted [81]. 
Analytical studies reported lipo-alkaloids as genuine minor compounds in raw plant material. The amount of these compounds is increasing during the traditional processing methods, while the amount of diester diterpene alkaloids are decreasing [82].

The semisynthesis of lipo-alkaloids have been successfully reproduced in laboratory by Csupor et al. [83] by modification of method reported by Bai et al. [7]. Similarly to the traditional method, the unavoidable part of the reported process is the heating step. As the result of this method, 14-benzoyl aconitane lipo-alkaloids with various fatty acids were produced (Fig 1) [83-85].

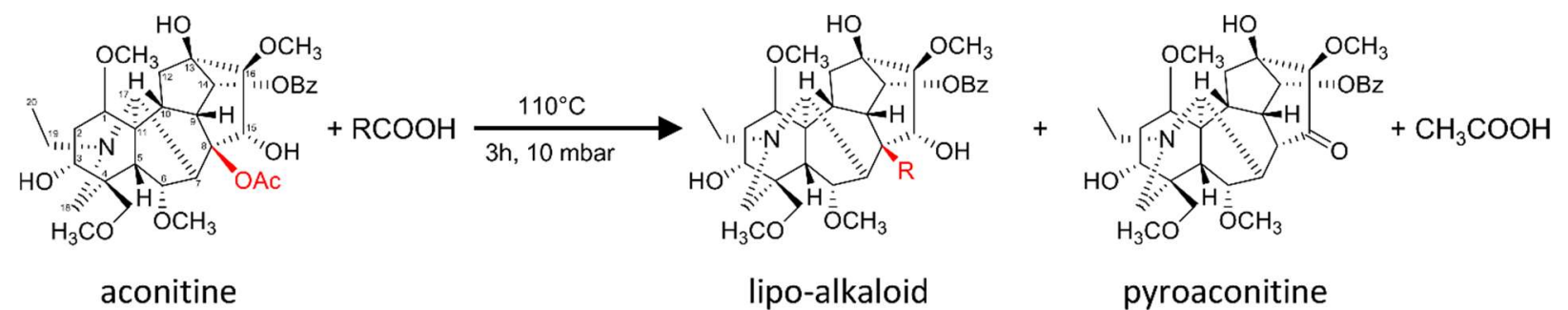

Figure 1. Semysinthesis of lipo-alkaloids

(R: laurate; myristate; palmitate; stearate; palmitoleate; oleate; $\gamma$-linolenate; eicosanoate; eicosa-11Z-enoate; eicosa-11Z,14Z-dienoate; eicosa-8Z,11Z,14Z-trienoate; eicosa-11Z,14Z,17Z-trienoate; eicosa-5Z,8Z,11Z,14Z-tetraenoate; eicosa-5Z,8Z,11Z,14Z,17Z-pentaenoate)

According to the bioactivity screening of these compounds, they are inhibitors of COX-1, COX-2, 5LOX enzymes and Nav1.2 channel. This could serve as explanation for the traditional application of aconite drugs as anti-inflammatory agents and as painkillers [85]. In vivo experiments, performed on mice, revealed that 14-Bz-aconitane lipo-alkaloids are far less toxic than aconitine (18). While animals treated with $0.3 \mathrm{mg} / \mathrm{kg}$ of aconitine (iv.) died immediately, all animals survived the treatment with dose higher than $10 \mathrm{mg} / \mathrm{kg}$ of lipo-alkaloids [82].

\subsubsection{Activity of aconite diterpene alkaloids on $\mathrm{Na}^{+}$and $\mathrm{K}^{+}$channels}

Toxicity of unprocessed Aconitum drugs is primarily explained by the $\mathrm{Na}^{+}$channel activating effect of some of their diterpene alkaloids (e.g. aconitine (18), hypaconitine (114) and mesaconitine(113)) $[86,87]$. Arrhythmogenic alkaloids have high affinity to the open $\mathrm{Na}^{+}$channels at the neurotoxin binding site 2; they activate these voltage-dependent $\mathrm{Na}^{+}$channels at their resting potential and inhibit their inactivation, resulting in a final inexcitability of the cells [88]. In case of fatal Aconitum poisoning, the major cause of death is usually arrhythmia or heart arrest [89].

Dzhakhangirov et al. [90] analysed the structure-cardiac activity relationships of 111 diterpene alkaloids in two animal arrhythmia models. All arrhythmogenic alkaloids possess an aconitane skeleton, but the substituents strongly influence their activity. In particular, a $\beta-\mathrm{OH}$ on C13 , an $\alpha$-O-aroyl on $\mathrm{C}-14$, a $\beta$-acetate on $\mathrm{C}-8$ and a positively charged nitrogen atom play key roles in the arrhythmogenic activity.

Interestingly, certain diterpene alkaloids have antiarrhythmic effect. This activity is mediated through their interaction with $\mathrm{K}^{+}$channels and the inhibition of the voltage-dependent 
$\mathrm{Na}^{+}$channels [88,91]. $\mathrm{Na}^{+}$channel-blocking diterpene alkaloids are competitive antagonists of the arrhythmogenic, $\mathrm{Na}^{+}$channel-activating alkaloids. The most active antiarrhythmic compounds are some $\mathrm{C}_{18}$ bisnorditerpene alkaloids. Their common structural features are the presence of an acetylanthranilic or anthranilic acid residue on C-4, methoxy groups on C-1, C-14 and C-16, and an $\mathrm{OH}$ on C-8 [90]. Lappaconitine, a member of this group, irreversibly blocks open human heart $\mathrm{Na}^{+}$channels [92] and interacts with $\mathrm{K}^{+}$channels [93].

Alkaloids from the $\mathrm{C}_{19}$ norditerpene group with antiarrhythmic activity typically have a basic nitrogen and possess an aromatic ester group on either C-1, C-6 or C-14 position. A representative of this group is 14-benzoyltalatisamine (115), which is a potent and selective blocker of the delayed rectifier $\mathrm{K}^{+}$channels [94].

Among the $C_{20}$ diterpene alkaloids, members of the Guan-Fu base series are the most promising antiarrhythmic compounds. Guan-Fu base A (= acehytisine) (120) blocks the fast $\mathrm{Na}^{+}$channel, exhibiting remarkable antiarrhythmic effect in rats [95] and increasing the diastolic period, thereby improving the myocardial blood supply [96]. In a patch-clamp experiment on guinea-pig myocytes, it inhibited the delayed rectifier current, which may contribute to the prolongation of cardiac repolarization [91].

Comprehensive investigation of cardioactive Aconitum alkaloids led to the development of a new group of antiarrhythmic drugs [97]. Lappaconitine (116) hydrobromide, produced from the roots of $A$. leucostomum and $A$. septentrionale was the first diterpenoid alkaloid-based drug on the market, approved in the 1980's as a class 1-C antiarrhythmic drug. Acehytisine (120), an alkaloid of A. koreanum, was approved for the treatment of paroxysmal supraventricular tachycardia in 2005 [98].

The human ether-à-go-go-related gene (hERG) encodes a voltage-gated potassium channel that provides the major repolarizing current (rapidly activating delayed rectifier potassium current, $\left.I_{K r}\right)$ in phase 3 of the cardiac action potential. Blockade of this channel may lead to the prolongation of the QT interval and thereby could enhance the risk of arrhythmia and sudden cardiac death [99]. The increased expression of GIRK (G protein-coupled inwardly-rectifying potassium) channels in the atria is associated with chronic atrial fibrillation [100], thus it is assumed that selective antagonists of these channels might be useful in the treatment of atrial fibrillation [101]. Therefore, selective blockers of GIRK channels without any inhibitory activity on hERG channels may be candidates for further studies focusing on their potential application as antiarrhythmics.

Interestingly, systematic studies on the effects of diterpene alkaloids on $\mathrm{K}^{+}$channels are scarce. A previous study reported the hERG channel inhibitory effect of aconitine (18) [102], which may also contribute to the toxicity of Aconitum plants. Later, an animal experiment confirmed similar activity for hypaconitine (114), confirming the QT prolonging potential of this compound 
[103]. For acehytisine (120), relatively weak hERG channel inhibitory activity was observed compared to the structurally related Guan-Fu base G (121), which justifies its superiority in case of human therapeutic application [104]. In one of our previous papers our group reported that aconitine (18), 14-benzoylaconine 8-O-palmitate (35), gigactonine (12), neolinine (16) and songoramine (31) demonstrated significant hERG channel inhibition using whole-cell patch clamp technique [105]. In a subsequent study, 15 diterpene alkaloids (aconosine (2), dolaconine (3), delavaconitine (4), acotoxicine (5), 14-deacetyl-18-demethyl-pubescenine (13), acotoxinine (14), neoline (15), neolinine (16), delectinine (17), aconitine (18), karakoline (19), senbusine A (20), senbusine C (21), songorine (30) and napelline (32)) were tested for their GIRK inhibitory activities, but none of them exerted remarkable activity. In this study, no hERG activity was recorded for neoline (15), karakoline (19), senbusine A (20), senbusine C (21) and napelline (32) [106].

Processing of aconite roots results in the transesterification of diester alkaloids with fatty acids at the C-8 carbon. The amount of the so-called lipo-alkaloids increases during processing, and in properly processed roots the major native alkaloids (aconitine (18), hypaconitine (114) and mesaconitine (113)) can be found only in traces. Contrary to aconitine-type alkaloids, lipo-alkaloids are substantially less toxic; the intravenous lethal single doses in animal experiments were of 3 magnitudes higher for the latter compounds [82].

\subsubsection{Phytochemistry and pharmacology of Spiraea genus}

Phytochemistry of 28 Spiraea taxa have been extensively studied. Mono- [107,108], di- [109-115], and triterpenes [116-121] have been isolated together with flavonoids [107,122-131], lignans [117,132-136], neolignans [137] and other phenylpropane derivatives $[117,118,120,129,133,136,138-145]$. Interestingly, only 9 of the investigated taxa contained diterpene alkaloids (S. formosana, S. fritschiana var. parvifolia, S. japonica, S. japonica var. acuta, S. japonica var. fortunei, S. japonica var. glabra, S. japonica var. incisa, S. japonica var. ovalifolia, S. japonica var. stellaris). From S. japonica 64 [114,146-164], from S. fritchiana 2 [148,152], from S. koreana [165] and from S. formosa 1 [137] diterpene alkaloids have been reported. All of the reported 65 diterpene alkaloids bear hetisine- and atisine-type $C_{20}$ basic skeletons (Fig 2) [166]. 


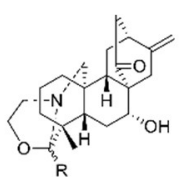

spiramine $Z-2(\mathbf{1 2 2})(R=\alpha-H)$ spiramine $Z-3(\mathbf{1 2 3})(R=\beta-H)$

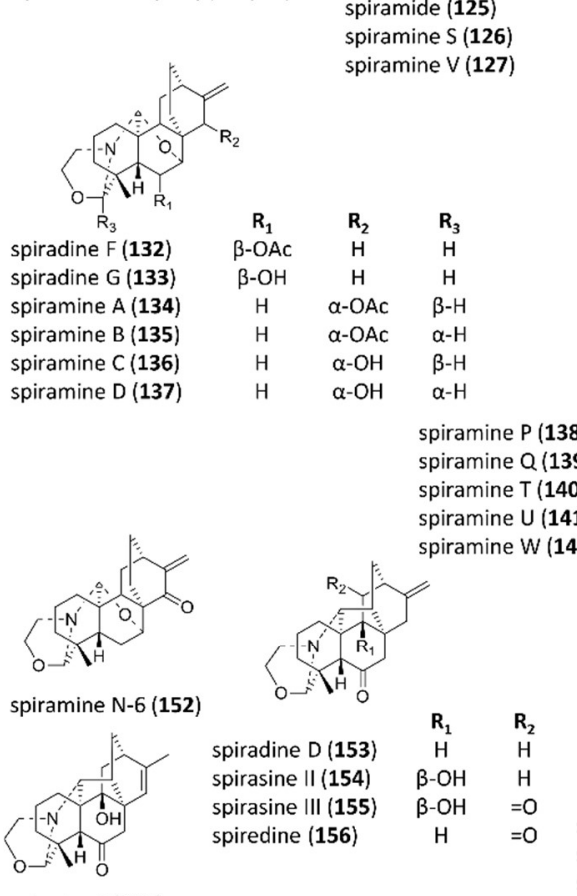

spirasine I (157)

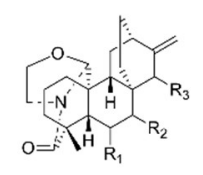

$\begin{array}{ccc}\mathbf{R}_{1} & \mathbf{R}_{\mathbf{2}} & \mathbf{R}_{\mathbf{3}} \\ \mathrm{H} & \alpha-\mathrm{OH} & \alpha-\mathrm{OH} \\ \beta-\mathrm{OAC} & \alpha-\mathrm{OAC} & \mathrm{H} \\ \mathrm{H} & \alpha-\mathrm{OH} & \beta-\mathrm{Ac} \\ \mathrm{H} & \alpha-\mathrm{OH}, \mathrm{Ac} & \alpha-\mathrm{OH}\end{array}$

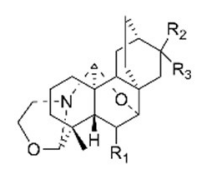

$\begin{array}{cc}\mathbf{R}_{1} & \mathbf{R}_{2} \\ \beta-\mathrm{OH} & \alpha-\mathrm{Me} \\ \beta-\mathrm{OH} & \beta-\mathrm{Me} \\ \beta-\mathrm{Ac} & \beta-\mathrm{Me} \\ \beta-\mathrm{OAc} & \alpha-\mathrm{Me} \\ \beta-\mathrm{OH} & \alpha-\mathrm{Me}\end{array}$

$\mathbf{R}_{\mathbf{3}}$

$\beta-\mathrm{OH}$
$\alpha-\mathrm{OH}$

$\alpha-\mathrm{OH}$

$\beta-\mathrm{OH}$

$\beta-\mathrm{OH}$
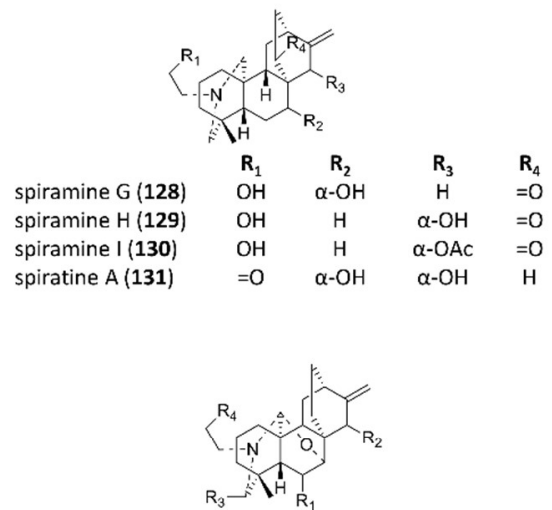

$\begin{array}{lcccc} & \mathbf{R}_{1} & \mathbf{R}_{\mathbf{2}} & \mathbf{R}_{\mathbf{3}} & \mathbf{R}_{\mathbf{4}} \\ \text { deacetylspiramine } F(\mathbf{1 4 3}) & \mathrm{H} & \mathrm{OH} & \mathrm{H} & \mathrm{OH} \\ \text { spiraeaine } \mathrm{A}(\mathbf{1 4 4}) & \beta-\mathrm{OH} & \mathrm{H} & \mathrm{H} & \mathrm{OH} \\ \text { spiramilactam A (145) } & \beta-\mathrm{OH} & \mathrm{H} & =\mathrm{O} & \mathrm{OH} \\ \text { spiramilactam B (146) } & \alpha-\mathrm{OH} & \mathrm{H} & =\mathrm{O} & \mathrm{OH} \\ \text { spiramine E (147) } & \mathrm{H} & \alpha-\mathrm{OAc} & \mathrm{H} & \mathrm{OAc} \\ \text { spiramine F (148) } & \mathrm{H} & \alpha-\mathrm{OAc} & \mathrm{H} & \mathrm{OH} \\ \text { spiramine R (149) } & \mathrm{H} & \alpha-\mathrm{OAc} & =\mathrm{O} & \mathrm{OH} \\ \text { spiramine X(150) } & \beta-\mathrm{OAc} & \mathrm{H} & =\mathrm{O} & \mathrm{OAc} \\ \text { spiramine } Y(\mathbf{1 5 1}) & \beta-\mathrm{OAC} & \mathrm{H} & =\mathrm{O} & \mathrm{OH}\end{array}$

spirasine $V(\mathbf{1 5 8})$ spirasine VI (159) spirasine VII (160) spirasine VIII (161)

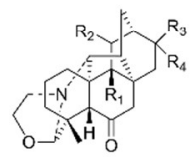

$\begin{array}{cc}\mathbf{R}_{1} & \mathrm{R}_{2} \\ \mathrm{H} & \mathrm{H} \\ \mathrm{H} & \mathrm{H} \\ \beta-\mathrm{OH} & \mathrm{H} \\ \beta-\mathrm{OH} & \mathrm{H}\end{array}$

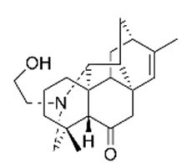

$\mathbf{R}_{4}$

$\mathbf{R}_{4} \quad$ spirafine II (162) $\beta-\mathrm{OH}$

$\alpha-\mathrm{OH}$

$\alpha-\mathrm{OH}$
$\beta-\mathrm{OH}$

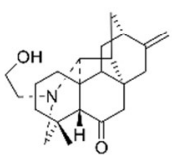

spirafine III (163)

\begin{tabular}{|c|c|c|c|c|c|c|c|c|c|}
\hline & $\mathbf{R}_{1}$ & $\mathbf{R}_{\mathbf{2}}$ & $\mathbf{R}_{\mathbf{3}}$ & $\mathbf{R}_{4}$ & & $\mathbf{R}_{\mathbf{1}}$ & $\mathbf{R}_{\mathbf{2}}$ & $\mathbf{R}_{\mathbf{3}}$ & $\begin{array}{l}\text { spiraqine }(193)(\mathrm{R}=\mathrm{H}) \\
\text { 6-hydroxyspiraquine }(194)(\mathrm{R}=\mathrm{OH})\end{array}$ \\
\hline 19-O-deethylspiramine $\mathrm{N}$ (164) & $\mathrm{H}$ & $\alpha-\mathrm{OH}$ & $\alpha-\mathrm{OH}$ & $\beta-\mathrm{OH}$ & spiradine A (173) & $\mathrm{B}-\mathrm{OH}$ & $=0$ & $\mathrm{H}$ & \\
\hline spiramine J (165) & H & $\alpha-\mathrm{OH}$ & $\alpha-\mathrm{OH}$ & $\alpha-\mathrm{CH}_{2}-\mathrm{AC}$ & spiradine B (174) & $\mathrm{B}-\mathrm{OH}$ & $\mathrm{OH}$ & H & \\
\hline spiramine K (166) & $\mathrm{H}$ & $\alpha-\mathrm{OH}$ & $\alpha-\mathrm{OH}$ & $\beta-\mathrm{CH}_{2}-\mathrm{AC}$ & spiradine C (175) & $\mathrm{B}-\mathrm{OH}$ & OAC & H & \\
\hline spiramine $L$ (167) & $\mathrm{H}$ & $\alpha-\mathrm{OH}$ & $\alpha-O A C$ & $\alpha-\mathrm{CH}_{2}-\mathrm{AC}$ & spirasine IV (176) & H & $=0$ & $\mathrm{H}$ & \\
\hline spiramine M (168) & $\mathrm{H}$ & $\alpha-O A C$ & $\alpha-\mathrm{OH}$ & $\beta-\mathrm{CH}_{2}-\mathrm{AC}$ & spirasine IX (177) & H & $\mathrm{H}$ & $=0$ & $\mathrm{O}=\mathrm{SH}_{\mathrm{O}}$ \\
\hline spiramine N (169) & H & $\alpha-\mathrm{OH}$ & $\alpha-\mathrm{OH}$ & $\beta-O E t$ & spirasine $X(\mathbf{1 7 8})$ & H & $=0$ & $\alpha-\mathrm{OH}$ & spirein (195) \\
\hline spiramine $\mathrm{O}(\mathbf{1 7 0})$ & $\mathrm{H}$ & $\alpha-\mathrm{OH}$ & $\alpha-\mathrm{OH}$ & $\beta$-OMe & spirasine XI (179) & $\mathrm{H}$ & $\mathrm{H}$ & $\alpha-\mathrm{OH}$ & \\
\hline spiramine Z (171) & $\beta$-OAC & $\alpha-O A C$ & $\mathrm{H}$ & OEt & spirasine XII (180) & $\mathrm{B}-\mathrm{OH}$ & $=0$ & $\alpha-\mathrm{OH}$ & \\
\hline spiratine B (172) & $\beta-O A c$ & $\alpha-O A c$ & H & $\mathrm{OH}$ & spirasine XIII (190) & $\mathrm{B}-\mathrm{OH}$ & $=0$ & $\beta-\mathrm{OH}$ & \\
\hline & & & & & spirasine XIV (191) & $\beta-\mathrm{OH}$ & $\mathrm{H}$ & $\alpha-\mathrm{OH}$ & \\
\hline & & & & & spirasine XV (192) & $\beta-\mathrm{OH}$ & $\mathrm{H}$ & $\beta-\mathrm{OH}$ & \\
\hline
\end{tabular}

Figure 2. $C_{20}$ diterpene alkaloids reported from Spiraea genus

The ethnomedicinal uses of Spiraea species have been documented in North America and Asia. The decoction of S. betulifolia was used as analgesic [167], in case of menstrual pain, heavy or prolonged menstruation, poor kidneys, ruptures, colds and abdominal pains [168] by Native Americans. In Traditional Chinese Medicine, S. japonica was used as a remedy for inflammation, cough, headache, and toothache [169]. Although the ethnomedicinal application of these species is marginal, various pharmacological studies have reported noteworthy activities of Spiraea extracts and pure compounds. 
Aqueous extract of $S$. aruncus [170] and alcoholic extract of $S$. thunbergii exerted antibacterial effect in vitro [171]. The volatile oils of S. alpina [172] and the decoction of S. salicifolia [173] exerted antifungal activity, similarly to the flavonoids and polyphenolic compounds isolated from Spiraea species $[140,174,175]$. The ethanolic extracts of S. alpina [176] and S. japonica var. acuminata exerted antiviral effect against tobacco mosaic virus. Spiramine $C(\mathbf{1 3 6})$, a $C_{20}$-diterpene alkaloid, exerted noteworthy antiviral effect, too [177].

Lignans (8'-hydroxylpinoresinol-8'-O-B-D-glucopyranoside, lyoniresinol-9-O- $\beta-D-$ glucopyranoside and isolariciresinol-9-O- $\beta$-D-glucopyranoside) obtained from Spiraea species were subjected to pharmacological examination. These compounds decreased significantly the levels of proinflammatory cytokines and interleukins (IL1B, IL6), which refers to their anti-inflammatory effects $[134,135]$. Atisine-type diterpene alkaloids suppressed the generation of NO in murine macrophage-like RAW 264.7 cells [118].

Hetisine-type diterpene alkaloids isolated from Spiraea species were tested as antiplatelet agents in vivo and in vitro by use of the methods of Born, Shen, and Hamburger. Vast majority of the tested Spiraea $\mathrm{C}_{20}$ diterpene alkaloids exerted selective inhibitory activity on PAF-induced platelet aggregation $[166,178,179]$.

The neuroprotective effect of spiramine T (140) was investigated. This compound reduced the content of lipid peroxide (LPO) significantly, increased the glutathione peroxidase (GSH-PX) activity, and inhibited the increase of nitric oxidase (NOS) activity and nitric oxide production in the cortex in gerbils, which were subjected to global forebrain ischemia and reperfusion [162]. Similarly, the ethanolic extract of Spiraea japonica var. acuta enhanced the recovery of EEG amplitude during reperfusion and decreased the water content in the cortex [166]. Further examination of Spiraea extracts and diterpene alkaloids for their neuroprotective effect seems to be promising.

Diterpene alkaloids exerted selective cytostatic activity in vitro. Spiramine C (136) and spiramine D (137) showed antiproliferative activity on MCF-7 cell line [180], while 15oxospiramilactone was potent in case of colon-cancer cell cell lines (SW-480 and Caco-2) [181].

\subsubsection{Phytochemistry and pharmacology of Ambrosia artemisiifolia}

The phytochemical investigations, beside the examination of the entire plant, are focusing mainly on the pollens. Flavonoids, phenolcarboxylic acids, and polyphenolic compounds have been reported from pollens and plant, as well $[182,183]$. The surface of the pollens is rich in proteins, peptides with immunoglobulin-E binding capacity (Amb a 1 and $A m b$ a 2 allergens) with ability to trigger rhinitis, oculorhinitis and other symptoms of hay fever [184]. Amb a proteins with pectate lyase [185] or protease activity [186] were not detected in other parts of the plant. 
Sesquiterpene lactones are the most characteristic compounds for Ambrosia genus. Since the vast majority of pharmacological experiments deals with these compounds, the literature overview is limited to sesquiterpene lactones reported from A. artemisiifolia. According to literature data, 29 sesquiterpene lactones have been isolated from A. artemisiifolia (Fig 3) [187199].
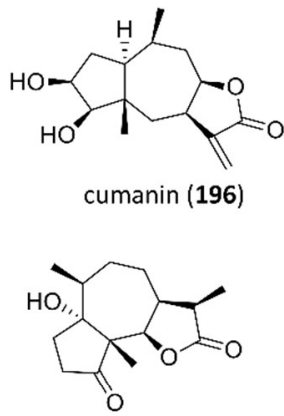

dihydrocoronopilin (201)

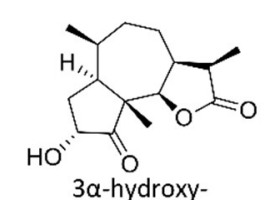

$11 \alpha \mathrm{H}, 13$-dihydrodamsin (206) $11 \alpha \mathrm{H}, 13$-dihydrodamsin (207)

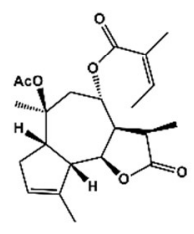

8-angeloyloxy-

10-acetoxyguai-3-en-6,12-olide (211)

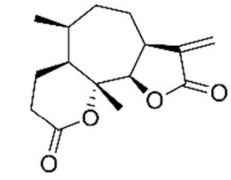

psilostachyin C (216)<smiles>C=C1CCC[C@]2(C)C[C@H]3OC(=O)C(=C)[C@H]3C[C@H]12</smiles>

isoalantolactone (221)
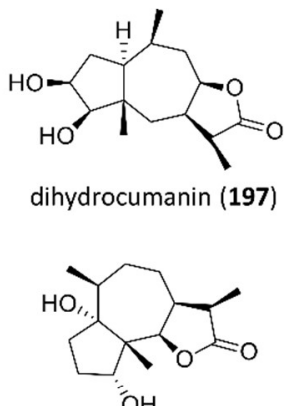

tetrahydrocoronopilin (202)
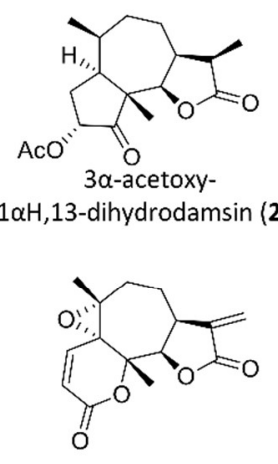

paulitin (212)

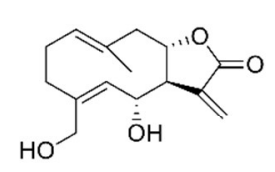

artemisiifolin (217)<smiles>C=C1CCC[C@]2(C)C[C@H]3OC(=O)[C@H](C)[C@H]3C[C@H]12</smiles>
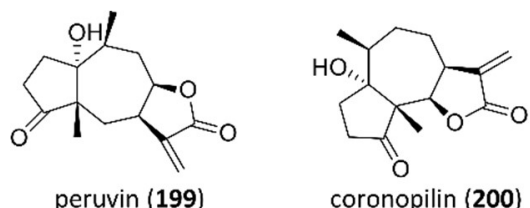

cumanin diacetate $(\mathbf{1 9 8})$

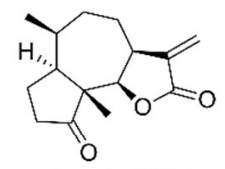

damsin (203)

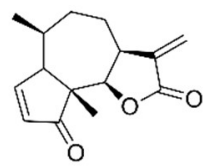

ambrosin (208)<smiles></smiles>

isopaulitin (213)

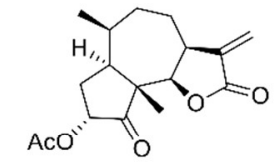

$3 \alpha$-acetoxydamsin (204)

11 $\alpha \mathrm{H}, 13$-dihydrodamsin (205)

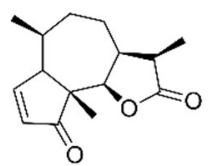

artesovin (209)<smiles>CC1C(=O)O[C@H]2[C@H]1CC[C@H](C)[C@@H](CCC(=O)O)[C@]2(C)C=O</smiles>

3,4-seco-ambrosanolide (210)<smiles>C=C1C(=O)O[C@H]2[C@@H]1CC[C@H](C)[C@@]1(C)CC(=O)[OH+][C@@H]21</smiles><smiles>C=C1C(=O)O[C@H]2[C@@H]1CCC(C)=C1CCC(=O)O[C@@]12C</smiles>

psilostachyin A (214)

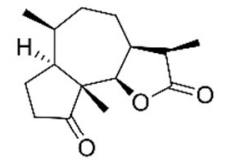

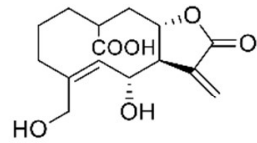

artemisiifolinic acid (218) isoartemisiifolinic acid (219)

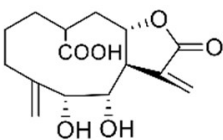

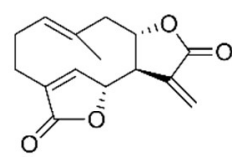

isabelin (220)

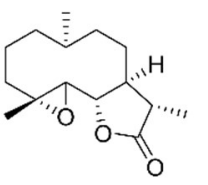

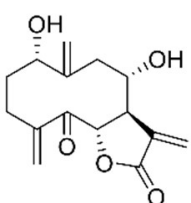

dihydroisoalantolactone (222)

Figure 3. Sesquiterpene lactone reported from Ambrosia artemisiifolia

Although A. artemisiifolia is native to North America, the medicinal application of this species was marginal among Native Americans. The studies on its ethnomedicinal use report primarily ethnographic aspects without discussing ethnopharmacological details [200-207]. The widespread and long-standing folk medicinal application of this plant is not supported by the available data. Though common ragweed had never been part of the folk medicine in Europe, the medicinal use of 
the herb (usually collected before the flowering period) has started recently and is spreading fast. To the best of our knowledge, neither the effects of long-term consumption, nor the expression of allergens (Amb a 1 and 2) has been examined previously, thus the risks of applying the herb for medicinal purposes is unknown.

Preclinical investigations of $A$. artemisiifolia were mainly conducted with its isolated compounds. Many of them were reported to have noteworthy pharmacological activities (Table 2), such as antibacterial, antifungal, antiprotozoal, anti-inflammatory, cardiovascular and hepatoprotective effects. The antiproliferative effects of sesquiterpene lactones of the Ambrosia genus has been widely examined on various tumour cell lines. However, no data is available on their cytotoxic effects on normal cells. 
Table 2. Bioactivity of ambrosian sesquiterpene lactones

\begin{tabular}{|c|c|c|c|c|c|}
\hline \multirow[b]{2}{*}{ Compounds } & \multicolumn{5}{|c|}{ Effects } \\
\hline & $\begin{array}{l}\text { Antileukemic } \\
\text { and anti- } \\
\text { lymphoma }\end{array}$ & Anti-cancer & Antiparasitic, insecticid & Antimicrobial & Other \\
\hline ambrosin (208) & $\begin{array}{l}\text { Jurkat cell line [208] } \\
\text { P-388 [209] }\end{array}$ & NF-KB inhibitor[210] & molluscicidal [211] & & $\begin{array}{l}\text { antiarrhythmic } \\
\text { effect [212] } \\
\text { allergenic [213] }\end{array}$ \\
\hline coronopilin (200) & $\begin{array}{l}\text { Jurkat cell line [214] } \\
\text { U937 [214] }\end{array}$ & $\begin{array}{l}\text { NF-KB inhibitor [215] } \\
\text { SAT3 activator [215] }\end{array}$ & larvicidal [216] & & allergenic [217] \\
\hline cumanin (196) & BW5147 [218] & & $\begin{array}{l}\text { trypanocidal [219] } \\
\text { antileishmanial [219] }\end{array}$ & & $\begin{array}{l}\text { anti-inflammatory } \\
{[220]}\end{array}$ \\
\hline damsin (203) & & $\begin{array}{l}\text { NF-KB inhibitor }[210,215] \\
\text { STAT3 activator [215] } \\
\text { prostate cancer (DU145) [221] }\end{array}$ & $\begin{array}{l}\text { antileishmanial [221] } \\
\text { trypanocidal [221] }\end{array}$ & $\begin{array}{l}\text { antituberculotic } \\
\text { [221] } \\
\text { antifungal [222] }\end{array}$ & $\begin{array}{l}\text { antyarrhytmic } \\
\text { [212] } \\
\text { allergenic [217] }\end{array}$ \\
\hline $\begin{array}{l}\text { dihydrocoronopilin } \\
\text { (201) }\end{array}$ & & & & $\begin{array}{l}\text { antibacterial } \\
{[223]}\end{array}$ & \\
\hline $\begin{array}{l}\text { dihydroisoalantolactone } \\
\text { (222) }\end{array}$ & & & larvicidal [224] & & \\
\hline isopaulitin (213) & & $\begin{array}{l}\text { human breast cancer cells (MCF-7, BCI) [225] } \\
\text { epidermoid carcinoma (A-431, KB) [225] } \\
\text { human colon cancer (Lu1) [225] } \\
\text { human lung cancer (Col) [225] }\end{array}$ & & & \\
\hline paulitin (212) & & $\begin{array}{l}\text { human breast cancer cells (MCF-7 [225], BCI [225]) } \\
\text { epidermoid carcinoma (A-431 [225], KB [225]) } \\
\text { human colon cancer (Lu1 [225]) } \\
\text { human lung cancer (Col) [225] }\end{array}$ & & & \\
\hline peruvin (199) & BW5147 [218] & breast cancer (aromatase inhibitor) [226] & $\begin{array}{l}\text { trypanocidal }[227,228] \\
\text { antileishmanial }[227,228] \\
\text { antiplasmodial }[229]\end{array}$ & & \\
\hline psilostachyin A (214) & BW5147 [218] & & $\begin{array}{l}\text { trypanocidal }[227,228,230,231] \\
\text { antileishmania }[227,228] \\
\text { antiplasmodial }[229]\end{array}$ & & $\begin{array}{l}\text { antimicrotubular } \\
\text { effect [198] }\end{array}$ \\
\hline psilostachyin B (215) & & & trypanocidal [232] & & \\
\hline
\end{tabular}




\begin{tabular}{|c|c|c|c|c|c|}
\hline \multirow[b]{2}{*}{ Compounds } & \multicolumn{5}{|c|}{ Effects } \\
\hline & $\begin{array}{c}\text { antileukemic } \\
\text { and anti- } \\
\text { lymphoma }\end{array}$ & anti-cancer & antiparasitic, insecticid & antimicrobial & other \\
\hline psilostachyin C (216) & BW5147 [218] & & trypanocidal $[230,233]$ & & $\begin{array}{l}\text { antimicrotubular } \\
\text { effect [198] }\end{array}$ \\
\hline isoalantolactone (221) & $\begin{array}{l}\text { K562/A02 [234,235] } \\
\text { deregulates Myb } \\
{[236]}\end{array}$ & $\begin{array}{l}\text { human breast cancer cells (MCF-7 [237-239], KT } \\
{[237,238,240], \text { MDA-MB-231 [239]) }} \\
\text { hepatocellular carcinoma [241] (HLE) [240,242] } \\
\text { gynecological cancer (HEC-1, HOC-21, HAC-2) [243] (HeLa) } \\
{[244,245],(\text { SKOV3) [246] }} \\
\text { osteosarcoma (U2OS) [247] } \\
\text { NF-kB [247] } \\
\text { Nrf2/ARE activator [248,249] } \\
\text { pancreatic carcinoma-1 (PANC-I) [250] } \\
\text { human gastric adenoma (MK-1 [244], SGC-7901 [251]) } \\
\text { melanoma [244] } \\
\text { human colorectal cells (HCT116) [252] } \\
\text { glial cell line (U251SP, T-98) [240] } \\
\text { head and neck squamous cell carcinoma (HNSCC) [253] } \\
\text { non-small-cell lung carcinoma [241] }\end{array}$ & larvicidal [216] & $\begin{array}{l}\text { antibacterial } \\
{[254,255]} \\
\text { antituberculotic } \\
{[256]}\end{array}$ & $\begin{array}{l}\text { allergenic [192] } \\
\text { plant growth } \\
\text { activity [257] }\end{array}$ \\
\hline
\end{tabular}




\section{MATERIALS AND METHODS}

\subsection{Plant material}

Aconitum napellus subsp. firmum (Reichenb.) Gáyer (syn. A. firmum) (SZTE-FG 806) was collected in the Retezat Mountains (South Carpathians, Romania) in August 2007, identified by Károly Csedő (University of Medicine and Pharmacy of Târgu Mureș, Târgu Mureș, Romania). The plant material was dried and stored at room temperature until processing.

Spiraea crenata L. (SZTE-FG 850) and S. salicifolia L. (SZTE-FG 851) were collected and identified by Gusztáv Jakab (Szent István University, Budapest, Hungary) in Sepsibükszád (Romania) and Alsórákos (Hungary). S. nipponica Maxim (SZTE-FG 852), S. x vanhouttei (Briot) Zabel (SZTE-FG 853) and S. x billardii Hort. ex K. Koch (SZTE-FG 854) were collected and identified by Anikó Németh (Botanical Garden of University of Szeged, Szeged, Hungary). S. media Schmidt. (DAU 031147 009) and S. chamaedryfolia L. (DAU 031145 023) were harvested in Daugavpils (Latvia). Identification was performed by Santa Rutkovska (University of Daugavpils, Latvia). Voucher specimens have been deposited in the herbarium of Department of Pharmacognosy (SZTE-FG 805, SZTE-FG 850-857) and University of Daugavpils (DAU 031147009 and DAU 031 145 023). The herbs and roots of plant materials were separated, dried and kept on room temperature until processing.

\subsection{Ragweed puree}

The analysed product "Keserú parlagfú készítmény 200 g" (in English: Bitter ragweed puree 200 g) was purchased online [258] in 2015. According to the product description, it contains a puree prepared from young and fresh ragweed herb (Ambrosia artesmisiifolia L.) and olive oil (the quantities of the components are not published).

\subsection{Diterpene alkaloids, lipo-alkaloids and fatty acids}

Diterpene alkaloids were obtained from plant sources $(A$. anthora L. $(6,7,29)[105], A$. moldavicum Hacq. $(9,11,12)$ [259], A. toxicum Rchb. $(2-5,12,14-16,18)$ [260,261], A. vulparia Rchb. $(8,10,17$, 26-28) [262], A. napellus L. subsp. firmum $(\mathbf{1 9 - 2 1 , 3 2 )}$ [106], and Consolida orientalis Gay. $(\mathbf{1}, \mathbf{1 3})$ [263]). Lipo-alkaloids (35-48) were yielded by semisynthesis $[83,84]$. The purity $(\geq 95 \%)$ of the isolated compounds was confirmed by HPLC and ${ }^{1} \mathrm{H}$ NMR spectroscopy.

The palmitoleic acid, $\gamma$-linolenic acid, eicosa-11Z,14Z-dienoic acid, eicosa-5Z,8Z,11Z,14Z-tetraenoic acid and eicosa-5Z,8Z,11Z,14Z,17Z-pentaenoic acid were purchased from Sigma-Aldrich. The purity of fatty acids was $\min .98 \%$. 


\subsection{Purification and isolation of the compounds}

4.4.1. Open column chromatography (CC) was carried out on $\mathrm{Al}_{2} \mathrm{O}_{3}$ column (Aluminium oxide 90 active neutral, Merck 1.01077) eluting with a gradient system of $n$-hexane-EtOAc-MeOH (50:50:1, 50:50:2, 50:50:4, 50:50:5, 50:50:10 and 0:0:1) gaining 125 fractions, the volume of collected fraction 1 was $100 \mathrm{~mL}$, fraction 125 was $250 \mathrm{~mL}$, further fractions were $10 \mathrm{~mL}$, each.

4.4.2. Gel filtration chromatography (GFC) was performed on Sephadex LH-20 (25-100 $\mu \mathrm{m}$, Pharmacia Fine Chemicals). The mixture of $\mathrm{CH}_{2} \mathrm{Cl}_{2}-\mathrm{MeOH}$ 1:1 was used as mobile phase, 20 fractions were collected. The fractions 1 and 20 were $10 \mathrm{~mL}$, further fractions were $2 \mathrm{~mL}$ respectively.

4.4.3. Centrifugal planar chromatography (CPC) was carried out with a Harrison Chromatotron (Model 8924, Harrison Research) on manually prepared $\mathrm{SiO}_{2}$ (Silica gel $60 \mathrm{GF}_{254}$, Merck 7730) plates, thickness $1 \mathrm{~mm}$ (CPCI, CPCII, CPCIII, CPCV, CPCVI, CPCVII) and $2 \mathrm{~mm}$ (CPCIV), flow rate $4 \mathrm{~mL} / \mathrm{min}$. Mobile phases:

CPCl: $\mathrm{CH}_{2} \mathrm{Cl}_{2}-\mathrm{MeOH}$ [1:1, 0:1 (250 then $150 \mathrm{~mL}$, respectively)]; volume of collected fractions: $10 \mathrm{~mL}$.

CPCII: $\mathrm{CH}_{2} \mathrm{Cl}_{2}-\mathrm{MeOH}$ [18:2, 0:10 (250 then $150 \mathrm{~mL}$, respectively)]; volume of collected fractions: $5 \mathrm{~mL}$.

CPCIII: $\mathrm{CH}_{2} \mathrm{Cl}_{2}-\mathrm{MeOH}$ [1:1, 0:1 (150 mL each)]; volume of collected fractions: $2 \mathrm{~mL}$.

CPCIV: toluene-acetone-EtOH-cc. $\mathrm{NH}_{3}-\mathrm{MeOH}$ [70:50:16:4.5:0, 0:0:0:0:1 (250 mL each)]; volume of collected fractions: $5 \mathrm{~mL}$.

CPCV: $\mathrm{CHCl}_{3}-\mathrm{MeOH}[1: 1,0: 1$ (100 then $150 \mathrm{~mL}$, respectively)]; volume of collected fractions: $2 \mathrm{~mL}$.

CPCVI: toluene-acetone-EtOH-cc. $\mathrm{NH}_{3}-\mathrm{MeOH}$ [70:50:16:4.5:0, 0:0:0:0:1 (500 then $150 \mathrm{~mL}$ respectively)]; volume of collected fractions: $10 \mathrm{~mL}$.

CPCVII: cyclohexane-toluene-EtOAc-MeOH [5:2:4:4, 0:0:0:1 (100 mL each)]; volume of collected fractions: $3 \mathrm{~mL}$.

4.4.4. Preparative layer chromatography (PLC) was performed on silica gel $(20 \times 20 \mathrm{~cm}$ Silica gel 60 $\mathrm{F}_{254}$, Merck 105554). Separation was monitored in UV light at $254 \mathrm{~nm}$ and by spraying the border of the plates with Dragendorff's reagent. Compounds were eluted from the scraped adsorbent with $\mathrm{CH}_{2} \mathrm{Cl}_{2}-\mathrm{MeOH}$ 9:1. Mobile phases:

PLCI: toluene-acetone-EtOH-cc. $\mathrm{NH}_{3}$ 70:50:16:4.5

PLCII: $\quad \mathrm{CH}_{2} \mathrm{Cl}_{2}-\mathrm{MeOH}$ 1:1 
4.4.5. Solid phase extraction (SPE) was carried out using normal phase column (Thermo Scientific, Hypersep SI, $200 \mathrm{mg} / 3 \mathrm{~mL}, 60108-410)$. Conditioning was carried out with $9 \mathrm{~mL}$ of $n$-hexane. The extract was loaded with $3 \mathrm{~mL}$ of $n$-hexane and washed with $6 \mathrm{~mL} n$-hexane. Elution was carried out with $n$-hexane $(3 \mathrm{~mL})$, EtOAc (15 mL, fractions), $\mathrm{CH}_{2} \mathrm{Cl}_{2}(9 \mathrm{~mL})$ and $\mathrm{MeOH}(9 \mathrm{~mL})$.

4.4.6. Thin layer chromatography (TLC) was used for the screening of compounds. TLC examination was carried out on silica gel (20x20 cm Silica gel $60 \mathrm{~F}_{254}$, Merck 105554). Each steps of separation were monitored at $254 \mathrm{~nm}$ and $366 \mathrm{~nm}$. In case of diterpene alkaloid examination, toluene-acetoneEtOH-cc. $\mathrm{NH}_{3}$ 70:50:16:4.5 was applied as mobile phase, and Dragendorff's reagent, and 5\% aqueous $\mathrm{NaNO}_{2}$ solvent were used for visualisation. In case of sesquiterpene lactones, toluene-EtOAc$\mathrm{HCOOH}$ 5:4:1 was applied as mobile phase, and the dried plates were sprayed with $c c . \mathrm{H}_{2} \mathrm{SO}_{4}$ and heated in oven set at $110^{\circ} \mathrm{C}$ for 5 minutes [264].

\subsection{Extraction of plant compounds}

\subsubsection{Preparation and phytochemical screening of $A$. napellus subsp. firmum extracts}

For screening the alkaloid content, $\mathrm{MeOH}$, alkaline and acidic extracts were prepared from dried and crushed roots, stems, leaves, flower and fruits.

$\mathrm{MeOH}$ extract: $1.0 \mathrm{~g}$ dried and crushed plant material was extracted with $10 \mathrm{~mL} \mathrm{MeOH}$ by ultrasonication at room temperature for $10 \mathrm{~min}$. After filtration, additional $5 \mathrm{~mL} \mathrm{MeOH}, 8 \mathrm{~mL}$ water and $2 \mathrm{~mL} 10 \% \mathrm{H}_{2} \mathrm{SO}_{4}$ were added to the extract, and solvent-solvent partitioning was carried out with $3 \times 10 \mathrm{~mL} \mathrm{CHCl}$. The $\mathrm{pH}$ of the aqueous phase was rendered to 12 with $5 \%$ aqueous $\mathrm{NaOH}$. Further solvent-solvent partitioning was carried out with $3 \times 10 \mathrm{~mL}$ of $\mathrm{CHCl}_{3}$ and the organic phases were collected.

Alkaline extract: $1.0 \mathrm{~g}$ dried and crushed plant material was extracted with $2 \mathrm{~mL} 5 \%$ aqueous solution of $\mathrm{NaOH}$ and $10 \mathrm{~mL} \mathrm{CHCl} 3$ by ultrasonication at room temperature for $10 \mathrm{~min}$. After filtration additional $5 \mathrm{~mL} \mathrm{CHCl}$ was added. The solvent-solvent partitioning was carried out with $3 \times 10 \mathrm{~mL} 2 \%$ aqueous $\mathrm{HCl}$. The $\mathrm{pH}$ of the aqueous phase was rendered to 12 with $5 \%$ aqueous $\mathrm{NaOH}$. Further solvent-solvent extraction was carried out with $3 \times 10 \mathrm{~mL} \mathrm{CHCl}$ and the organic phases were collected.

Acidic extract: $1.0 \mathrm{~g}$ dried and crushed plant material was extracted with $10 \mathrm{~mL} 2 \%$ aqueous $\mathrm{HCl}$ by ultrasonication at room temperature for $10 \mathrm{~min}$. After filtration additional $5 \mathrm{~mL} 2 \%$ aqueous $\mathrm{HCl}$ was added and the $\mathrm{pH}$ was rendered to 12 with $5 \%$ aqueous $\mathrm{NaOH}$. Then the alkaloids were extracted with $3 \times 10 \mathrm{~mL} \mathrm{CHCl}$. The extracts were subsequently evaporated under vacuum at $40{ }^{\circ} \mathrm{C}$. Finally, the dried residue was dissolved in $1 \mathrm{~mL} \mathrm{MeOH}$. 
Screening for alkaloid content of the different extracts was carried out by TLC and HPLC (Waters 600, Waters Corporation, Milford, USA), equipped with a 2998 photodiode array detector, on-line degasser and autosampler, using a reversed phase Gemini NX C18 110 A, $100 \times 4.6$ mm, $5 \mu \mathrm{m}$ column (Phenomenex, Torrance, USA). Gradient elution was applied, using $10 \mathrm{mM} \mathrm{CH}_{3} \mathrm{COONH}_{4}$ buffer pH 8.9 (eluent A) and AcNi (eluent B) (eluent B 30-40-45-80-30\% in 0-4-20-30-70 min) at flow rate of $1.1 \mathrm{~mL} / \mathrm{min}$. Alkaloids were detected in the whole UV wavelength range and specifically at $233 \mathrm{~nm}$.

\subsubsection{Preparation of crude alkaloid extract from Aconitum napellus subsp. firmum}

Dried and crushed tubers and roots ( $280 \mathrm{~g}$ ) of $A$. napellus subsp. firmum were extracted with 2500 $\mathrm{mL}$ of $2 \%$ aqueous $\mathrm{HCl}$ by ultrasonication at room temperature for $15 \mathrm{~min}$. The $\mathrm{pH}$ of the filtered solution was rendered to 12 with $5 \%$ aqueous $\mathrm{NaOH}$ and extracted with $\mathrm{CHCl}_{3}(4 \times 750 \mathrm{~mL}$ ). The organic layer was evaporated under vacuum at $40{ }^{\circ} \mathrm{C}$ to give the alkaloid fractions $(3.1 \mathrm{~g})$ as a yellowish syrupy residue.

\subsubsection{Preparation of Spiraea extracts for alkaloid-content screening}

All Spiraea species were screened for alkaloid-content. The same neutral, alkaline and acidic extraction methods were applied as described in Section 4.5.1.

\subsubsection{Preparation of Spiraea chamaedryfolia fractions}

Dried and crushed herb materials were extracted consequently with $\mathrm{MeOH}, \mathrm{CHCl}_{3}$ and $2 \%$ aqueous $\mathrm{HCl}$ by ultrasonication at room temperature for $15 \mathrm{~min}$. The applied drug-solvent ratio was 1:5. The drug was dried before each extraction. Moistening with $5 \%$ aqueous $\mathrm{NaOH}$ solvent was applied prior extraction with chloroform.

The $\mathrm{MeOH}$ extract was acidified with $2 \%$ aqueous $\mathrm{HCl}$ and extracted with $\mathrm{CHCl}_{3}$. Fraction M1 was obtained by collecting and evaporating the organic phase. The $\mathrm{pH}$ of aqueous phase was rendered to alkaline $\left(\mathrm{pH}\right.$ 12) with $5 \%$ aqueous $\mathrm{NaOH}$ and extracted with chloroform. The $\mathrm{CHCl}_{3}$ phase yielded fraction $\mathrm{M} 2$.

The $\mathrm{CHCl}_{3}$ extract was extracted with $2 \%$ aqueous $\mathrm{HCl}$. The organic phase was evaporated and named as fraction L1. The $\mathrm{pH}$ of aqueous phase was made alkaline and extracted with $\mathrm{CHCl}_{3}$. The organic phase was evaporated affording fraction $L 2$.

The acidic extract was subjected to solvent-solvent partitioning with $\mathrm{CHCl}_{3}$, after adjusting the $\mathrm{pH}$ to alkaline. The dry residue of the organic phase was labelled as $\mathrm{S1}$. The $\mathrm{pH}$ of aqueous phase was rendered to acidic with $2 \%$ aqueous $\mathrm{HCl}$ and extracted with $\mathrm{CHCl}_{3}$. The organic phase was evaporated affording fraction S2. 


\subsection{Identification and structure elucidation of compounds}

\subsubsection{Identification of diterpene alkaloids by LC-MS}

Screening for the known diterpene alkaloids in the alkaline and $\mathrm{MeOH}$ extracts of $A$. napellus subsp. firmum was carried out by LC-MS. Chromatographic separation was performed using a Shimadzu system (2 pumps (LC-20AD); UV-Vis detector (SPD-20A); autosampler (SIL-20A); controller (CBM20A); degasser (DGU-20A3) equipped with a reversed phase Gemini NX C18 110 A 100 x 4.6 mm 5 $\mu \mathrm{m}$ column (Phenomenex, Torrance, USA). Mobile phase $\mathrm{A}$ was $\mathrm{MeOH}$ and $\mathrm{B}$ was $\mathrm{CH}_{3} \mathrm{COONH}_{4}$ buffer (10 mM, pH=8.9). Gradient elution was applied (eluent B 60-5-5-60-60\% in 0-35-36-42-45 $\mathrm{min}$ ) at flow rate of $1 \mathrm{~mL} / \mathrm{min}$. The HPLC was coupled to an API $2000 \mathrm{MS} / \mathrm{MS}$ with an atmospheric pressure chemical ionization (APCI) interface. The source temperature was $350^{\circ} \mathrm{C}$.

\subsubsection{Sesquiterpene lactone content identification in common ragweed puree}

$150 \mathrm{mg}$ of the ragweed puree was extracted with $2 \mathrm{~mL}$ of $n$-hexane by ultrasonication for $10 \mathrm{~min}$. The fractions, rich in sesquiterpene lactones were prepared by solid phase extraction (SPE, Hypersep SI 200 mg/3 mL, 60108-410 Thermo Scientific) and screened by TLC.

The presence of sesquiterpene lactones was confirmed by LC-MS. The dry residue of the analysed fraction was dissolved in $\mathrm{MeOH}-\mathrm{H}_{2} \mathrm{O}$ 2:1 and filtered on $0.45 \mu \mathrm{m}$ nylon filter. The volume of the injected sample was $5 \mu \mathrm{L}$. Chromatographic separation was performed with an Agilent $1260 \mathrm{HPLC}$ equipped with a reversed phase Agilent $3.0 \times 50$ mm $2.7 \mu \mathrm{m}$ column (Agilent Poroshell 120 EC-C18). Mobile phase consisted of $0.1 \% \mathrm{HCOOH}$ in LC-MS quality water (eluent A) and $0.1 \% \mathrm{HCOOH}$ in LCMS quality AcNi (eluent B). Gradient elution was applied (eluent B 5-40-95-5-5\% in 0-3-7-20-20.1$22 \mathrm{~min}$ ). The flow rate was $0.5 \mathrm{~mL} / \mathrm{min}$. The column temperature was set up to $40^{\circ} \mathrm{C}$. The HPLC was coupled to an Agilent 6460A Triple Quadrupole Mass Spectrometer. MS detection was carried out in full scan mode ( $\mathrm{m} / \mathrm{z}$ range: $50-2000$, fragmentor: $75 \mathrm{~V}$, positive polarity, standard JetStream ion source settings). Data acquired and evaluated using MassHunter software v. B.03. Expected $m / z$ values were extracted from the total ion current chromatogram.

\subsubsection{Structure elucidation}

NMR spectra were recorded in $\mathrm{CDCl}_{3}$ on a Bruker Avance DRX 500 spectrometer at $500 \mathrm{MHz}\left({ }^{1} \mathrm{H}\right)$ or $125 \mathrm{MHz}\left({ }^{13} \mathrm{C}\right)$; the signals of the deuterated solvents were taken as the reference. Chemical shifts were referenced to the residual solvent's reconances $\left({ }^{1} \mathrm{H}\right) .2 \mathrm{D}$ data were acquired and processed with standard Bruker software. In the ${ }^{1} \mathrm{H}-{ }^{1} \mathrm{H}$ COSY, NOESY, HSQC, and HMBC experiments, gradientenhanced versions were used. 


\subsection{Pharmacological tests}

Pharmacological investigations were performed in cooperation with the Rytmion Ltd. (Szeged, Hungary, principal investigator: László Tálos), Department of Public Health (University of Szeged, Faculty of Medicine, principal investigator: Andrea Szabó), and Department of Psychiatry (University of Szeged, Faculty of Medicine, principal investigator: Zsolt László Datki).

\subsubsection{GIRK channel inhibitory assay}

Experiments with diterpene alkaloids were performed on HEK293 cells stably expressing the GIRK1/4 (Kir3.1/3.4) K+ channels. GIRK channel inhibitory assay was developed by the adaptation of the manual patch-clamp method of Hashimoto et al. [265] to the automated planar patch clamp technology. The cell line was purchased from UCL Business PLC. Propafenone (Sigma-Aldrich Ltd., purity $>98 \%$ ) was used as a positive control. For the detailed protocol of GIRK assay, see refs $[84,106]$.

\subsection{2. hERG channel inhibitory assay}

A modified assay by Polonchuk [266] was used for measurements of hERG channel effect of the diterpene alkaloids. Measurements were performed on HEK293 cells stably expressing the hERG $\left(K_{v} 11.1\right) K^{+}$channel. The cell line was purchased from Cell Culture Service. $10 \mu \mathrm{M}$ amitriptyline (Sigma-Aldrich Ltd., purity $>98 \%$ ) was applied as a reference inhibitor. For the detailed protocol of hERG assay, see refs $[84,106]$.

\subsubsection{Screening for antibacterial activity}

The following microorganisms were employed as test strains in the screening assay of Spiraea extracts: 3 Gram-positive strains namely, Bacillus subtilis (ATCC 6633), Staphylococcus aureus (ATCC 29213), Streptococcus pneumoniae (ATCC 49619) and one Gram-negative strain, Moraxella catarrhalis (ATCC 25238). In addition, one multiresistant strain, namely methicillin-resistant Staphylococcus aureus (MRSA, ATCC 43300) was also used as test organism. The test organisms were cultured on standard Mueller-Hinton agar plates or Columbia agar $+5 \%$ sheep blood (COS) plates (bioMérieux) at $37^{\circ} \mathrm{C}$. The bacterial cultures were maintained in their appropriate plates at $4{ }^{\circ} \mathrm{C}$ throughout the experiment and used as stock cultures.

The antibacterial activity of plant extracts was evaluated with disc-diffusion method. The bacterial isolates for screening assay were prepared by picking single colony from $24 \mathrm{~h}$ old plates and it was suspended in sterile, isotonic saline solution $(5 \mathrm{~mL})$ to reach $0.5 \mathrm{McFarland}$ standard of optical turbidity, resulting a suspension containing approximately $1-2 \times 10^{8} \mathrm{CFU} / \mathrm{mL}$. The bacterial suspension was spread on sterile appropriate plates by sterile cotton swab. Sterile filter paper discs 
( $6 \mathrm{~mm}$ of diameter) were loaded with the extracts ( $20 \mu \mathrm{L}$ of dried extracts redissolved in $\mathrm{EtOH}-\mathrm{H}_{2} \mathrm{O}$ 4:6 at $50 \mathrm{mg} / \mathrm{mL}$ ) and after drying they were placed on the plates. Negative controls were performed with paper discs impregnated with $20 \mu \mathrm{L}$ of solvent. The plates were then incubated at $37{ }^{\circ} \mathrm{C}$ for $24 \mathrm{~h}$ under aerobic conditions. The diameters of inhibition zones produced by the plant extracts were measured and recorded (diameter of the inhibition zone plus diameter of the disc).

\subsubsection{Xanthine oxidase assay}

The method used for the testing of Spiraea extracts is based on a continuous spectrophotometric rate determination: the absorbance of $\mathrm{XO}$ enzyme induced uric acid production from xanthine was measured at $290 \mathrm{~nm}$ for $3 \mathrm{~min}$. The enzyme-inhibitory effect was determined by the decreased production of uric acid. The final reaction mixture in $300 \mu \mathrm{L}$ well was: $100 \mu \mathrm{L}$ xanthine $(0.15 \mathrm{mM}$, $\mathrm{pH} 7.5), 150 \mu \mathrm{L}$ potassium buffer ( $50 \mathrm{mM}, \mathrm{pH} 7.5)$ and $50 \mu \mathrm{L}$ XO solution ( 0.2 Units $/ \mathrm{mL}$ ) for enzymeactivity control. XO, isolated from bovine milk (lyophilized powder) and xanthine powder were purchased from Sigma-Aldrich Co. The reaction mixture for inhibition: $100 \mu \mathrm{L}$ xanthine, $140 \mu \mathrm{L}$ buffer, $10 \mu \mathrm{L}$ test (S. chamaedryfolia fractions $12 \mathrm{~g} / \mathrm{mL}, 600 \mu \mathrm{g} / \mathrm{mL}$ diluted in DMSO solution) and $50 \mu \mathrm{L}$ XO. Allopurinol was dissolved in DMSO and used as positive control $(100 \%$ inhibition was considered at $10 \mu \mathrm{g} / \mathrm{mL}$ concentration of allopurinol).

\subsubsection{Bdelloid rotifer assays}

In vivo experiments were performed using Philodina acuticornis odiosa (PA) with diterpene alkaloids. Rotifer culturing method and the methods for non-invasive (TSL: toxicity and survival lifespan; BSI: body size index; MCF: mastax contraction frequency assay) and invasive (CRC: cellular reduction capacity) experimental monitoring assays were performed according to modified method by Olah et al. (2017) [267]. For the detailed protocol of assays, see refs $[267,268]$.

Toxicity and survival lifespan (TSL) assay: The impact of the test compounds on the lifespan of unfed PA rotifers was assessed. The morphological viability markers, chosen for evaluation were taken over from Poeggeler et al. [269]; expanded and defined in Olah et al. [267].

Body size index (BSI) measurement: Rotifers never stop growing; therefore, the length/width of the animal in correlation with time (body size index; BSI) increases continuously within the speciesspecific limit.

Mastax contraction frequency (MCF) assay: The mastax (pharynx) is part of the digestive system. To evaluate and standardize the viability of one-housed rotifers in our experiments, MCF (contraction/sec) was used as a quantitative viability marker.

Cellular reduction capacity (CRC) assay: The CRC gives information about the scale of reduction capacity and oxidative stress triggered by treatment in rotifers. For measuring the EZ4U Cell 
Proliferation Assay (non-radioactive cell proliferation, cytotoxicity and reduction capacity assay with XTT solution) was used (cat. no.: BI-5000; Biomedica Hungary). The absorbance was measured by a microplate-reader (Spectramax 384, Molecular Science, Hungary) set at $491 \mathrm{~nm}$ with $630 \mathrm{~nm}$ as a reference.

\subsubsection{Repeated dose toxicity on rats}

The 28 days lasting experiment with ragweed puree was carried out on male SPF Wistar rats. The ragweed puree was administered per os using cookie doughs as vehicles. As no previous animal study was found in the literature with ragweed puree doses, they were determined according to the following toxicological calculations. Dosage recommendation on the label of the ragweed puree was considered as human median effective dose $\left(\mathrm{ED}_{50}\right)$. Control animals [CON, $\mathrm{n}=8$ ] received plain cookie dough without ragweed ( $0 \mathrm{~m} / \mathrm{m} \%$ in dough). Low dose animals [LD, $\mathrm{n}=8$ ] received $500 \mathrm{mg} / \mathrm{kg}$ b. w. ragweed ( $12.5 \mathrm{~m} / \mathrm{m} \%$ in dough), while high dose rats [HD, $n=8]$ were given $1000 \mathrm{mg} / \mathrm{kg} \mathrm{b}$. w. ragweed ( $25 \mathrm{~m} / \mathrm{m} \%$ in dough). During experiment the 407 OECD Guidelines for the Testing of Chemicals [270] and protocols approved by the Committee on the Ethics of Animal Experiments of the University of Szeged and the Directorate of Food Safety and Animal Health Care, Government Agency of Csongrád County (Permit number: XXI./151/2013.) were followed.

General clinical observations were done every day. After the treatment period the animals were over-anaesthetized with isoflurane inhalation. The rats were dissected and blood samples were taken immediately from vena cava. From blood samples, serum was separated for estimation of various blood chemical parameters, levels of cholesterol, triglyceride, high-density lipoprotein (HDL), low-density lipoprotein (LDL), alanine aminotransferase (ALT), aspartate aminotransferase (AST), alkaline phosphatase (ALP), gamma-glutamyl transferase (GGT), bilirubin, carbamide, creatinine; number of leukocytes, number and proportion of neutrophils, lymphocytes, monocytes, eosinophils, basophils; number of erythrocytes, haemoglobin, haematocrit, mean corpuscular volume (MCV), mean corpuscular haemoglobin $\mathrm{MCH}$, mean corpuscular haemoglobin concentration $(\mathrm{MCHC})$, red cell distribution width (RDW-CV), number of thrombocytes, and mean platelet volume (MPV). The main organs were removed and weighed (brain, liver, lungs, heart, kidneys, spleen, thymus and adrenals), as organ weight is a sensitive basic toxicological indicator. Since absolute organ weight is influenced by the whole body weight, therefore organ-to-body weight ratio (related to $100 \mathrm{~g}$ b.w.) was calculated. For further details see reference [271]. 


\subsection{Microscopical analysis}

Spiraea chamaedryfolia secondary root was softened by ultrasonication in hot water for $1 \mathrm{~h}$. Unembedded material was sectioned on sledge microtome. Sections were cut $100 \mu \mathrm{m}$ thick. Observations were made on unstained sections. For histological characterisation $1 \%$ aqueous toluidine blue, and for alkaloid localisation Dragendorff's reagent was used. Transverse sections were mounted with water-glycerol 1:1. The sections were observed under light microscope and photographic images were captured using a digital camera.

\subsection{Statistical analysis}

The distribution of data was checked for normality by Shapiro-Wilk test. In case of normal distribution two sample Student's test, one-way ANOVA and post hoc Bonferroni test $(p<0.05)$ were used. When a variable was not normally distributed, Kruskal-Wallis test was used for evaluation. In case of significance $(p<0.05)$ the data were tested using the Mann-Whitney test, to show which groups are significantly different from each other. The experimental data are expressed as the mean $\pm \mathrm{SD}$ or mean $\pm \mathrm{SEM}$. All statistical analyses were carried out in $\mathrm{R}$ (version 3.3.2, The $\mathrm{R}$ Foundation for Statistical Computing, Vienna, Austria, http://www.r-project.org). 


\section{RESULTS}

\subsection{Isolation and detection of aconite alkaloids}

The alkaloid content of various plant parts of $A$. napellus subsp. firmum was screened and the neutral, alkaline and acidic extraction methods were compared using TLC and HPLC methods (see sections 4.4.6. and 4.5.1.). It was concluded that the highest alkaloid-content can be found in roots and tubers. Among the three compared extraction methods the acidic was supposed to be the most effective (Fig 4), thus it was applied for further isolation work.

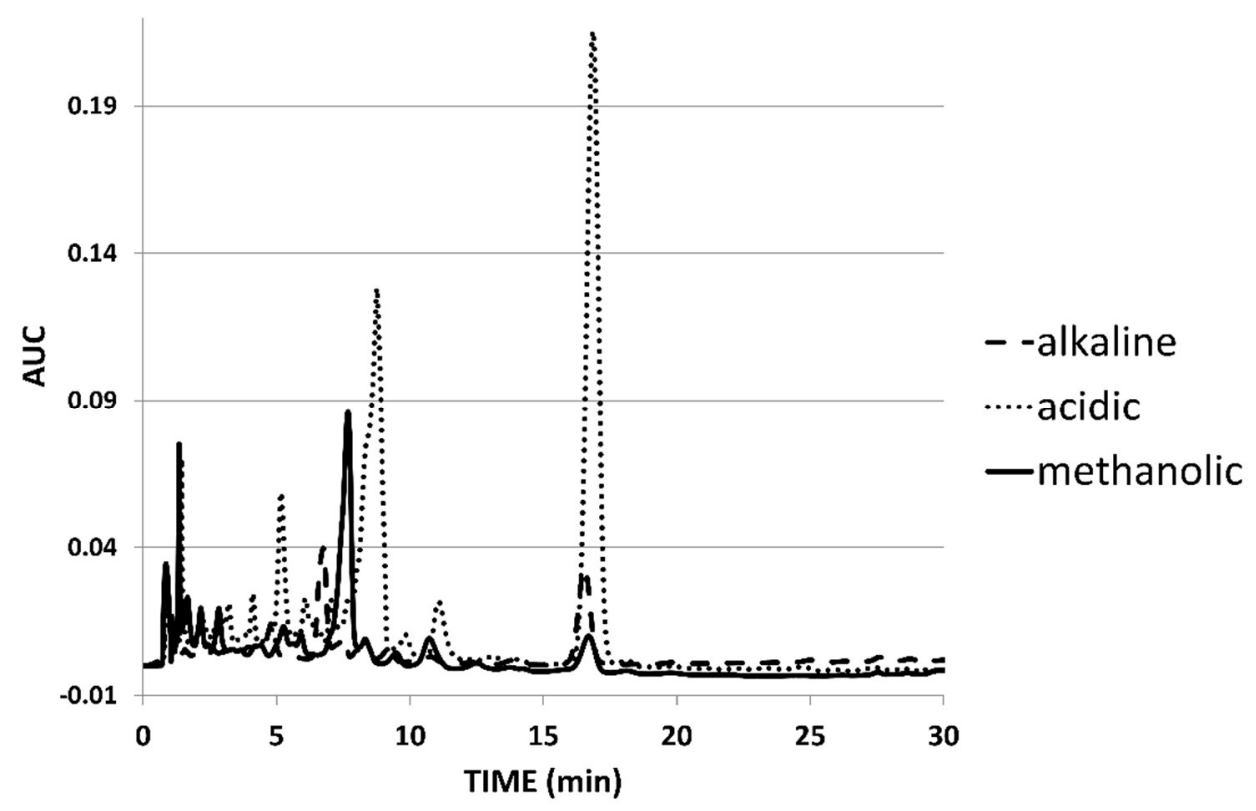

Figure 4. Overlaid HPLC-DAD chromatogram of $A$. napellus subsp. firmum extracts $(\lambda=233 \mathrm{~nm}$ )

The alkaloid-rich fraction for preparative phytochemical purposes was prepared by applying acidic extraction followed by solvent-solvent partitioning (see section 4.5.2.) The obtained yellowish syrupy crude alkaloid fraction ( $3.1 \mathrm{~g}$ ) was chromatographed on $\mathrm{Al}_{2} \mathrm{O}_{3}$ column (CC) eluting with a gradient system gaining 125 fractions. Fractions with similar alkaloid content were combined after TLC monitoring.

Fractions 58-64 eluted with $n$-hexane-EtOAc-MeOH 50:50:5 afforded AF1 (40.0 mg) in pure form. Fractions 72-83 were subjected first to gel filtration chromatography (GFC). Subfractions of this separation were purified by centrifugal planar chromatography (CPCI) and then by preparative layer chromatography (PLC I), yielding AF2 (5.7 mg). Fractions 84-94 were purified by CPC II. Subfractions 20-28 obtained here were subjected first to CPC III then to PLC II, to afford AF3 (1.4 mg). Subfractions 29-40 were purified by PLC III and yielded AF4 (2.4 mg). Fractions 102-104 of 
CC were purified by centrifugal planar chromatography in four steps (CPC IV-CPC VII), affording AF5 (3.4 mg) and AF6 (8.3 mg) (Fig 5-6).

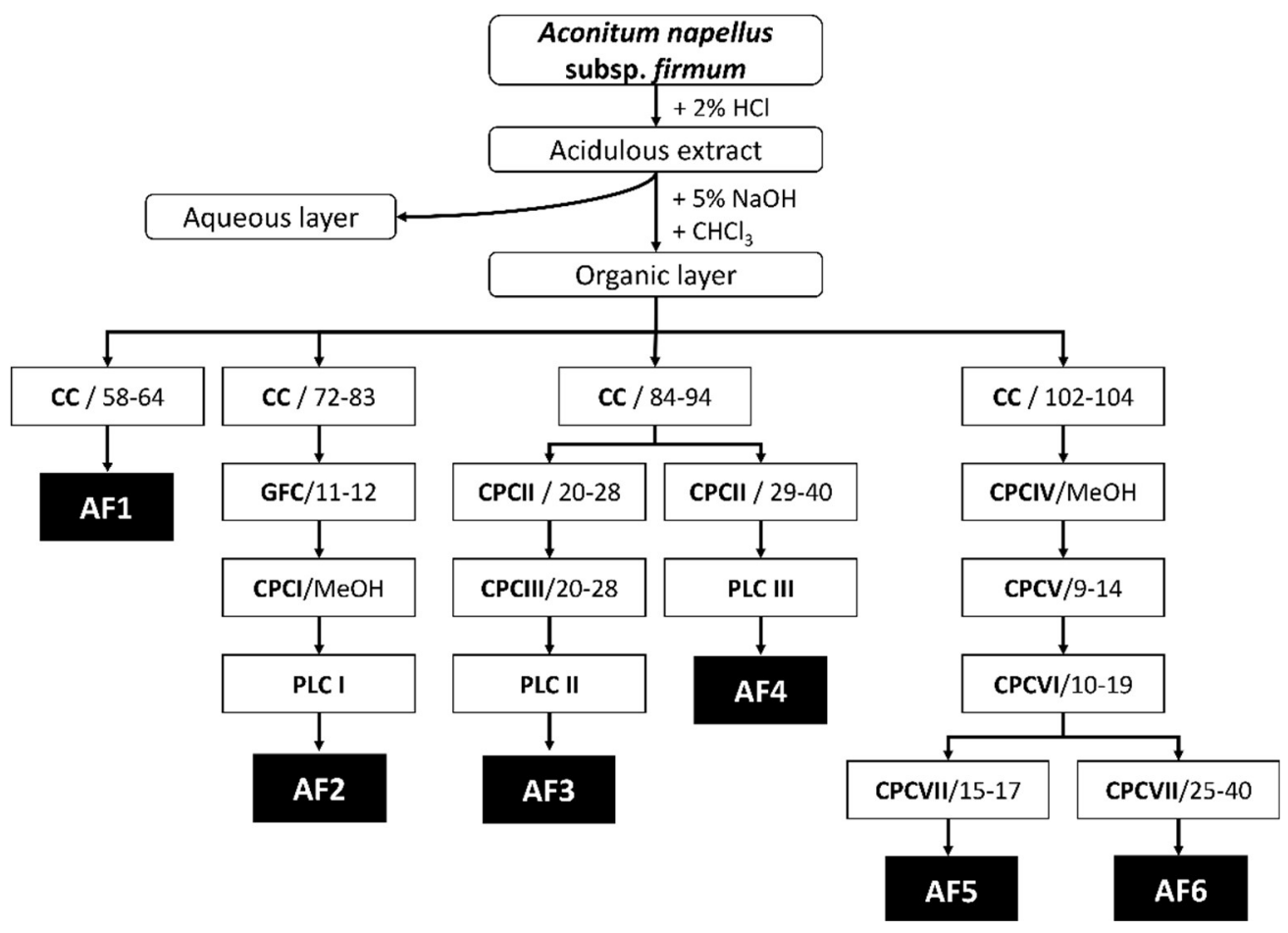

Figure 5. Isolation of alkaloids from A. napellus subsp. firmum

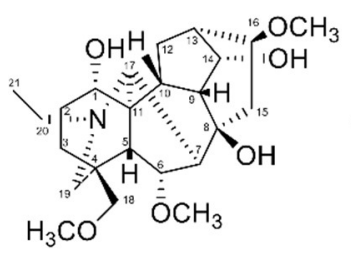

neoline (AF1; 15)

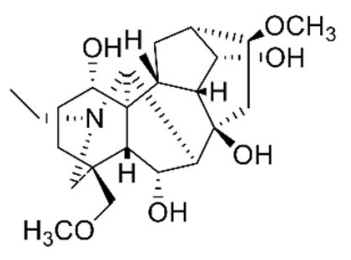

senbusine $A(\mathbf{A F 5} ; \mathbf{2 0})$

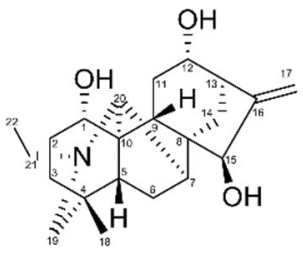

napelline (AF2; 32)

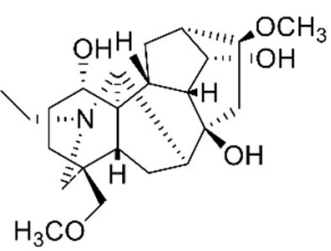

isotalatizidine (AF3; 6)

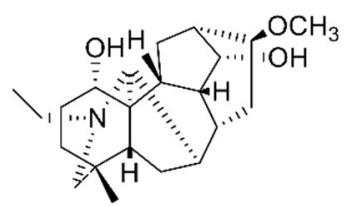

karakoline (AF4; 19)

Figure 6. The six isolated (AF1-6) and two identified compounds from A. napellus subsp. firmum

The compounds were identified by means of ${ }^{1} \mathrm{H}$ and ${ }^{13} \mathrm{C}$ NMR spectroscopy. Neoline (AF1; 15) [272], napelline (AF2; 32) [273,274], isotalatizidine (AF3; 3) [105], karakoline (AF4; 19) [275,276], senbusine A (AF5; 20) [277] and senbusine C (AF6; 21) [273] were identified by comparison of their NMR spectroscopic data with literature data. On the basis of our $2 \mathrm{D} N M R$ investigations $\left({ }^{1} \mathrm{H},{ }^{1} \mathrm{H}\right.$ COSY, HSQC, HMBC, NOESY) of napelline (AF2; 32) the previously reported ${ }^{1}{ }^{H}$ NMR data [273] were completed, since only a few ${ }^{1} \mathrm{H}$ chemical shift value were published earlier. In addition, the ${ }^{13} \mathrm{C} \mathrm{NMR}$ 
assignments of C-2, C-3, C-5, C-9, C-11, C-13 and C-14 were revised as listed in the Table 3, with regard to the $\mathrm{HMBC}$ correlations. The ${ }^{1} \mathrm{H}$ NMR $\left(500 \mathrm{MHz}, \mathrm{CDCl}_{3}\right)$ assignment of all protons of senbusine C (AF6; 21) were determined by 2D NMR and literature data [273] were supplemented and corrected with full ${ }^{1} \mathrm{H}-\mathrm{NMR}$ assignment.

Table 3. NMR spectral data of napelline (AF2; 32) $\left[500 \mathrm{MHz}, \mathrm{CDCl}_{3}, \delta(\mathrm{ppm})(\mathrm{J}=\mathrm{Hz})\right]$

\begin{tabular}{|c|c|c|c|}
\hline Atom & ${ }^{1} \mathrm{H}$ & ${ }^{13} \mathrm{C}$ & HMBC (H No.) \\
\hline 1 & $3.93 \mathrm{dd}(8.0,6.1)$ & 69.8 & $3 a, 3 b$ \\
\hline $2 a$ & $2.00 \mathrm{~m}$ & 31.7 & $18,19 b$ \\
\hline $2 b$ & $1.88 \mathrm{dd}(12.9,5.8)$ & & \\
\hline $3 a$ & $1.64 \mathrm{dt}(8.0,5.4)$ & 36.0 & $1,5,7,11 a, 14 a, 14 b$ \\
\hline $3 b$ & $1.36 \mathrm{~m}$ & & \\
\hline 4 & - & 34.0 & $2 b, 3 a, 3 b / 5,17,19 b$ \\
\hline 5 & $1.36 \mathrm{~m}$ & 48.2 & $3 a, 3 b / 6 b, 7,9,18$ \\
\hline $6 a$ & $2.46 \mathrm{~m}$ & & - \\
\hline $6 b$ & $1.36 \mathrm{~m}$ & 23.4 & \\
\hline 7 & $2.11 \mathrm{~d}(5.3)$ & 43.8 & $5 / 6 b, 14 b$ \\
\hline 8 & - & 50.3 & $6 a, 6 b, 9,11 a, 14 a, 14 b$ \\
\hline 9 & $1.45 \mathrm{dd}(12.9,6.3)$ & 36.2 & 9,12 \\
\hline 10 & - & 52.9 & $1,5,7,9,11 b$ \\
\hline $11 a$ & $2.00 \mathrm{~m}$ & 30.8 & $1,3 a, 3 b$ \\
\hline $11 b$ & $1.79 \mathrm{~m}$ & & \\
\hline 12 & $3.56 \mathrm{dd}(9.5,6.8)$ & 76.2 & 13, 14a, 14b, 17 \\
\hline 13 & $2.46 \mathrm{~m}$ & 47.1 & $11 a, 14 a, 14 b, 17$ \\
\hline $14 a$ & $1.92 \mathrm{~d}(12.3)$ & 28.5 & 9 \\
\hline $14 b$ & $1.06 \mathrm{dd}(12.3,4.3)$ & & \\
\hline 15 & $4.19 \mathrm{~s}$ & 77.7 & $13,14 a, 14 b, 17$ \\
\hline 16 & - & 159.1 & $12,13,14 a, 17$ \\
\hline $17 a$ & $5.17 \mathrm{~d}(1.5)$ & 108.7 & 13 \\
\hline $17 \mathrm{~b}$ & $5.15 \mathrm{~d}(1.5)$ & & \\
\hline 18 & $0.78 \mathrm{~s}$ & 26.4 & $3 a, 3 b, 19 b$ \\
\hline 19a & $2.46 \mathrm{~d}(11.4)$ & 58.3 & $3 a, 3 b, 18$ \\
\hline $19 b$ & $2.26 \mathrm{~d}(11.4)$ & & \\
\hline 20 & $3.39 \mathrm{~s}$ & 66.0 & $3 a, 3 b, 18$ \\
\hline $21 a$ & $2.58 \mathrm{dq}(14.0,7.2)$ & & 22 \\
\hline $21 b$ & $2.46 \mathrm{dq}(14.0,7.2)$ & 51.0 & \\
\hline 22 & $1.08 \mathrm{t}(7.2)$ & 13.2 & - \\
\hline
\end{tabular}

Senbusine C (AF6; 21). Colourless amorphous solid; ${ }^{1} \mathrm{H}-\mathrm{NMR}\left(500 \mathrm{MHz}, \mathrm{CDCl}_{3}\right): 3.67(1 \mathrm{H}, \mathrm{s}, \mathrm{H}-1)$, 1.50 (1H, m, H-2a), 1.62 (1H, dd, J 4.7, $13.2 \mathrm{~Hz}, \mathrm{H}-2 \mathrm{~b}), 1.88$ (1H, m, H-3a),: 1.60 (1H, m, H-3b), 2.18 $(1 \mathrm{H}, \mathrm{d}, J 6.9 \mathrm{~Hz}, \mathrm{H}-5), 4.12$ (d, J $6.9 \mathrm{~Hz}, \mathrm{H}-6), 2.35(1 \mathrm{H}, \mathrm{s}, \mathrm{H}-7), 2.15$ (1H, dd, J 5.5, 5.9 Hz, H-9), 1.88 (1H, m, H-10), 1.81 (1H, dd, J 14.0, 4.5 Hz, H-12a), 2.03 (1H, m, H-12b), 2.25 (1H, dd, J 5.0, 6.7 Hz, $\mathrm{H}-13), 4.11(1 \mathrm{H}, \mathrm{t}$, J $4.6 \mathrm{~Hz}, \mathrm{H}-14), 4.41(1 \mathrm{H}, \mathrm{d}$, J $6.6 \mathrm{~Hz}, \mathrm{H}-15), 3.16(1 \mathrm{H}, \mathrm{d}, J 6.7 \mathrm{~Hz}, \mathrm{H}-16), 2.74(1 \mathrm{H}$, s, H-17), 3.19 (d, J 8.2 Hz, H-18a), 3.65 (1H, d, J 8.1 Hz, H-18b), 2.30 (1H, d, J 10.5 Hz, H-19a), 2.71 (d, J $10.6 \mathrm{~Hz}, \mathrm{H}-19 \mathrm{~b}), 2.44$ (1H, dq, J 13.2, 7.2 Hz, H-20a), 2.75 (1H, m, H-20b), 1.12 (3H, t, J $7.2 \mathrm{~Hz}$, $\mathrm{H}-21), 3.35$ (3H, s, 6-OMe), 3.45 (3H, s, 16-OMe), 3.33 (3H, s, 18-OMe). 
The $\mathrm{MeOH}$ and alkaline extract were tested for compounds previously detected in this species by LC-MS comparing the quasimolecular ions and fragmentation pattern of the compounds with literature data. The MRM transitions for neoline (AF1; 15) $(438 \rightarrow 420)$ [278], karakoline (AF4; 19) $(378 \rightarrow 360)$, napelline (AF2; 32) $(360 \rightarrow 342)$, isotalatizidine (AF3; 6) $(408 \rightarrow 390)$, senbusine $A$ (AF5; 20) $(424 \rightarrow 406)[279]$, senbusine C (AF6; 21) $(454 \rightarrow 436)$ [279], aconitine (AF7; 18) $(646 \rightarrow 586)$ [82], mesaconitine (113) $(632 \rightarrow 572)$ [82], hypaconitine $(114)(616 \rightarrow 556)$ [82], songorine (30) $(358 \rightarrow 340)$ [280], 15-acetylsongorine $(400 \rightarrow 340), 3$-deoxyaconitine $(630 \rightarrow 570),(342 \rightarrow 324)$, tadzhaconine $(534 \rightarrow 474)$ and taurenine $(22)(496 \rightarrow 436)$ were screened. The LC-MS analysis resulted in the identification of six alkaloids (AF1-AF6; 6, 15, 19-21, 32) isolated from crude extracts and further two known alkaloids aconitine (AF7; 18) and taurenine (AF8; 22) (Fig 7). Interestingly, the other alkaloids previously reported from $A$. napellus subsp. firmum could not be detected.
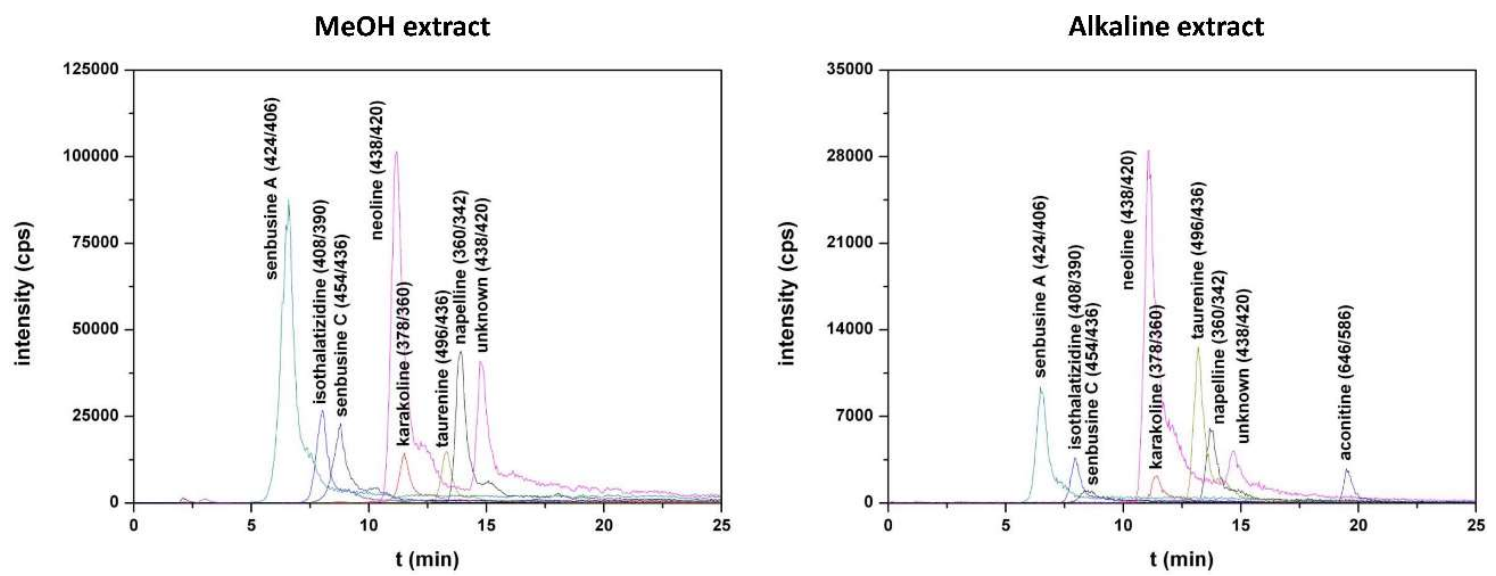

Figure 7. Identification of isolated compounds by LC-MS (overlaid MRM chromatograms of $A$. napellus subsp. firmum extracts)

Although all isolated compounds (AF1-AF6; 6, 15, 19-21, 32) are known in A. napellus species [276,281], napelline (32), isotalatizidine (3), karakoline (19), and senbusine C (21) were detected for the first time from A. napellus subsp. firmum taxon.

\subsection{Investigation of Spiraea species for alkaloid content}

Phytochemical screening revealed alkaloid content in S. chamaedryfolia roots, nevertheless the other six Spiraea species were alkaloid-free. The solvent-solvent partitioning of $\mathrm{MeOH}$, acidic and alkaline extracts of $S$. chamaedryfolia resulted in alkaloid-rich $\mathrm{EtOAc}, \mathrm{CHCl}_{3}$ and $\mathrm{MeOH}$ fractions (Fig 8). The most apolar fraction prepared with $n$-hexane was alkaloid free. The attempt to isolate diterpene alkaloids has failed due to the low stability of compounds. 


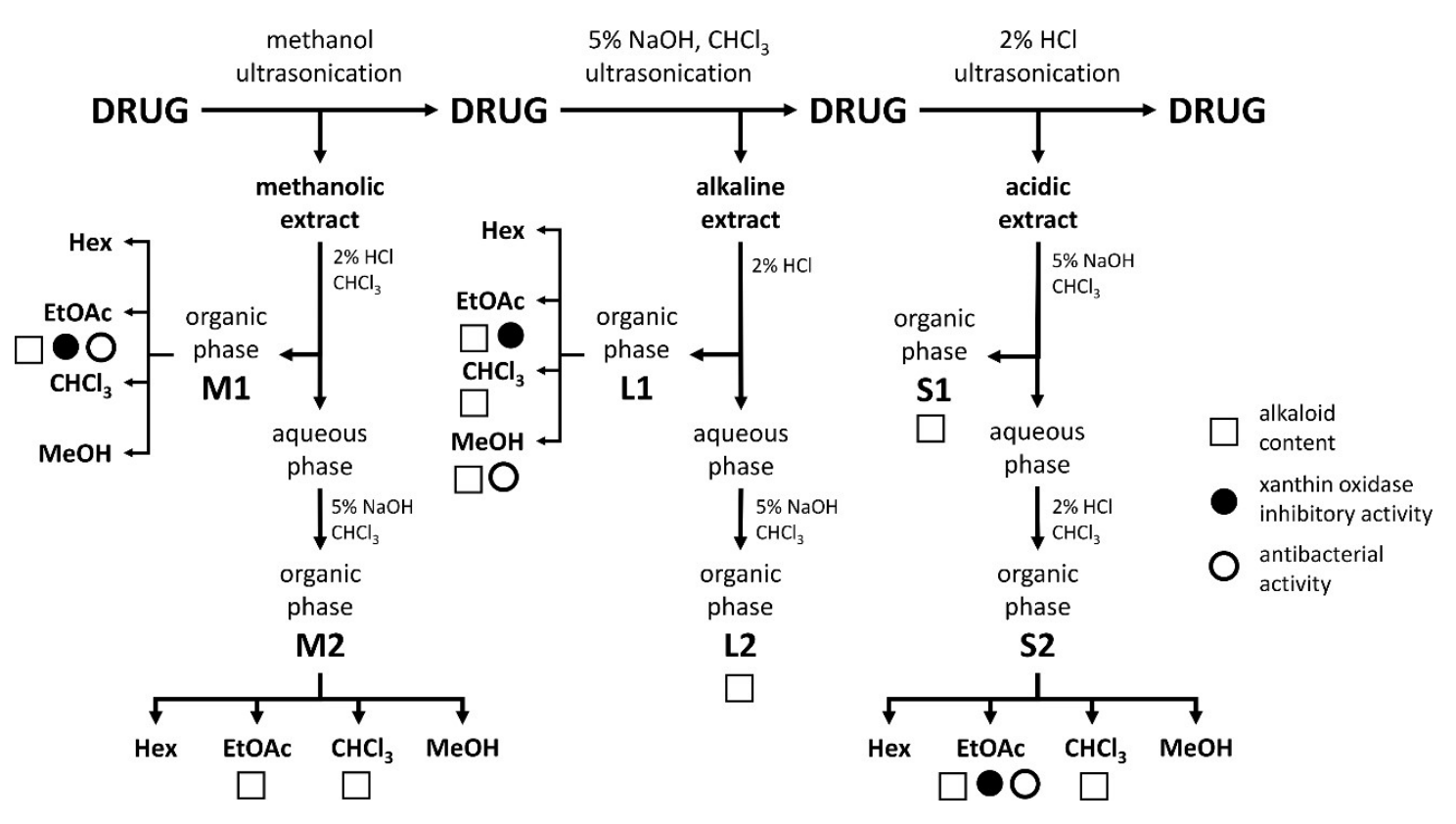

Figure 8. Alkaloid content and biological activities of S. chamaedryfolia

On the transverse section of $S$. chamaedryfolia root, the characteristic structures for secondary root can be observed (Fig 9). The periderm, primary and secondary cortex, and xylems with medullary rays can be observed on unstained section. The primary and secondary cortex with fibers in primary cortex are becoming observable after staining with toluidine blue. Dragendorff's reagent reveals the presence of alkaloids in secondary cortex and secondary xylem, while there was no alkaloid in the pith.

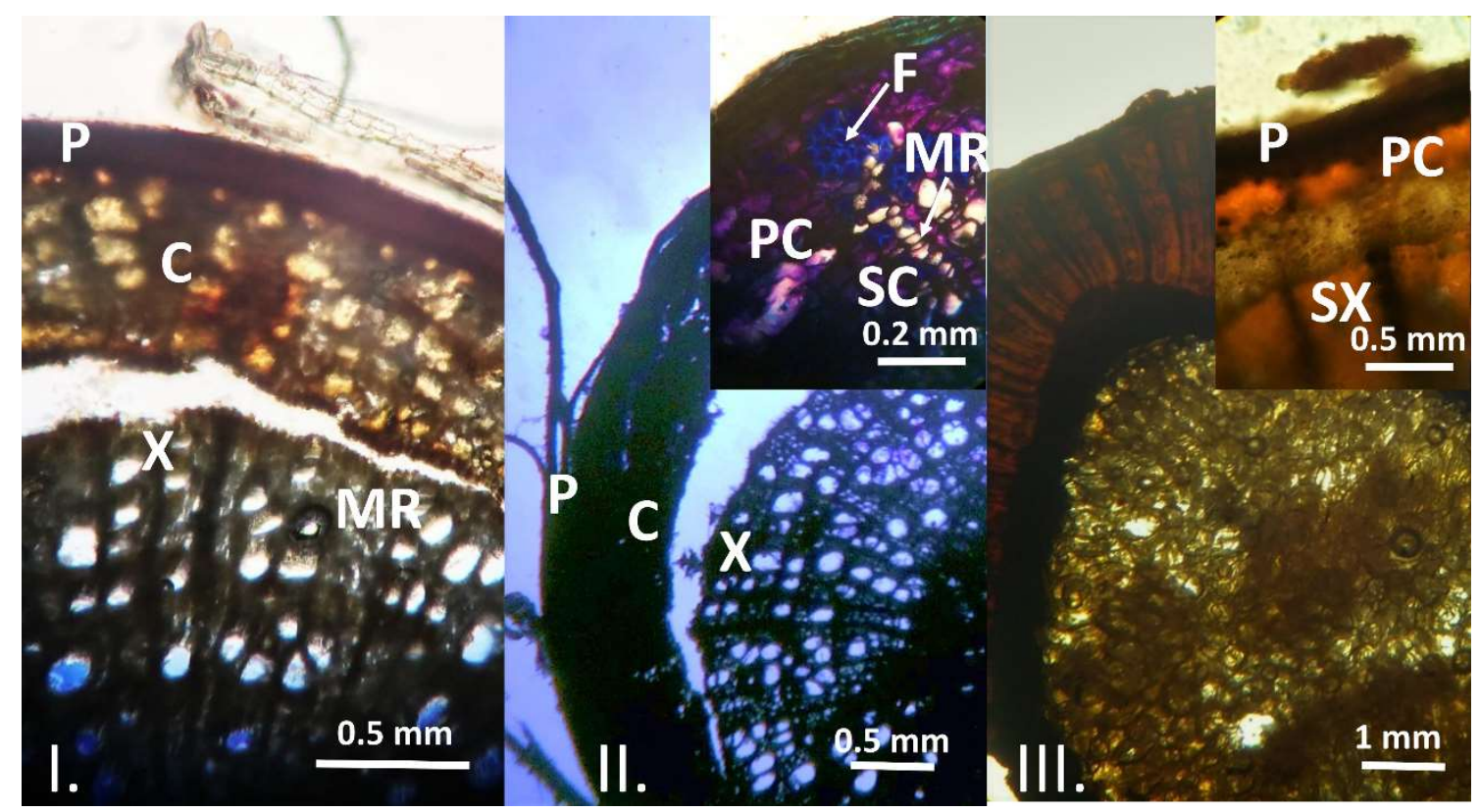

Figure 9. The unstained (I.), stained with $1 \%$ toluidine blue (II.) and Dragendorff's reagent (III.) transverse sections of Spiraea chamaedryfolia secondary root

(P: periderm, C: cortex, PC: primary cortex, SC: secondary cortex, $\mathbf{X}$ : xylem, SX: secondary xylem, MR: medullary ray) 


\subsection{Pharmacological activity of aconite alkaloids}

\subsubsection{Activity on GIRK and hERG potassium channels}

The inhibitory activity on cardiac potassium (GIRK and hERG) channels and structure-activity relationship of diterpene alkaloids (1-32) and a series of fatty acids (palmitoleic acid, $\gamma$-linolenic acid, eicosa-11Z,14Z-dienoic acid, eicosa-5Z,8Z,11Z,14Z-tetraenoic acid and eicosa5Z,8Z,11Z,14Z,17Z-pentaenoic acid) was investigated, together with lipo-alkaloids (33-46) (Table 4) $[105,106,282]$.

Table 4. GIRK and hERG activities of compounds (mean $\pm S D, N=3$ ) (Data were published in ref ${ }^{\text {a }}$ [105])

\begin{tabular}{|c|c|c|c|c|c|}
\hline & \multicolumn{2}{|c|}{$\begin{array}{c}\text { GIRK } \\
\text { inhibitory activity (\%) }\end{array}$} & \multicolumn{3}{|c|}{$\begin{array}{c}\text { hERG } \\
\text { inhibitory activity (\%) }\end{array}$} \\
\hline & $1 \mu \mathrm{M}$ & $10 \mu \mathrm{M}$ & $1 \mu \mathrm{M}$ & $10 \mu \mathrm{M}$ & $30 \mu \mathrm{M}$ \\
\hline takaosamine (1) & $3 \pm 26$ & $20 \pm 5$ & & $12.5 \pm 2.9^{a}$ & \\
\hline aconosine (2) & $15 \pm 6$ & $24 \pm 9$ & & $15.3 \pm 3.5^{\mathrm{a}}$ & \\
\hline dolaconine (3) & $4 \pm 21$ & $10 \pm 16$ & & $8.3 \pm 1.4^{a}$ & \\
\hline delavaconitine (4) & $28 \pm 10$ & $44 \pm 3$ & & & \\
\hline acotoxicine (5) & $15 \pm 1$ & $31 \pm 7$ & & $17.3 \pm 3.3^{\mathrm{a}}$ & \\
\hline isotalatizidine (6) & $21 \pm 0$ & $30 \pm 1$ & & $19.1 \pm 3.2^{\mathrm{a}}$ & \\
\hline 10-hydroxy-8-O-methyltalatizamine (7) & $-3 \pm 6$ & $-5 \pm 58$ & & $15.8 \pm 1.1^{\mathrm{a}}$ & \\
\hline delcosine $(\mathbf{8})$ & $23 \pm 18$ & $45 \pm 1$ & & $17.9 \pm 2.4^{\mathrm{a}}$ & \\
\hline ajacine (9) & $25 \pm 8$ & $33 \pm 3$ & & $13.0 \pm 1.7^{a}$ & \\
\hline lycoctonine (10) & $0 \pm 4$ & $11 \pm 26$ & & $13.7 \pm 3.3^{a}$ & \\
\hline swatinine (11) & $28 \pm 5$ & $37 \pm 1$ & & $8.9 \pm 1.6^{a}$ & \\
\hline gigactonine (12) & $13 \pm 3$ & $27 \pm 4$ & & $38.0 \pm 7.4^{a}$ & \\
\hline 14-desacetyl-18-demethylpubescenine (13) & $16 \pm 6$ & $33 \pm 9$ & & $6.5 \pm 1.9^{a}$ & \\
\hline acotoxinine (14) & $11 \pm 8$ & $35 \pm 2$ & & $6.5 \pm 2.2^{\mathrm{a}}$ & \\
\hline neoline (15) & $17 \pm 1$ & $32 \pm 18$ & $3 \pm 4$ & $19 \pm 5$ & \\
\hline neolinine (16) & $17 \pm 4$ & $35 \pm 12$ & & $35.8 \pm 4.7^{a}$ & \\
\hline delectinine (17) & $30 \pm 1$ & $40 \pm 7$ & & $7.7 \pm 2.3^{\mathrm{a}}$ & \\
\hline aconitine (18) & $15 \pm 9$ & $45 \pm 9$ & & $44.9 \pm 7.4$ & \\
\hline karakoline (19) & $10 \pm 2$ & $17 \pm 1$ & $3 \pm 7$ & $16 \pm 10$ & \\
\hline senbusine A (20) & $19 \pm 1$ & $26 \pm 8$ & $4 \pm 1$ & $11 \pm 0$ & \\
\hline senbusine C (21) & $17 \pm 5$ & $20 \pm 9$ & $-1 \pm 10$ & $3 \pm 19$ & \\
\hline acovulparine (26) & $12 \pm 9$ & $26 \pm 6$ & & $10.8 \pm 2.3^{a}$ & \\
\hline septentriodine (27) & $23 \pm 10$ & $37 \pm 13$ & & $20.9 \pm 1.0^{\mathrm{a}}$ & \\
\hline finetiadine (28) & $9 \pm 11$ & $0 \pm 8$ & & & \\
\hline hetisinone (29) & $11 \pm 8$ & $25 \pm 12$ & & $14.3 \pm 3.9^{a}$ & \\
\hline songorine $(\mathbf{3 0})$ & $10 \pm 10$ & $47 \pm 9$ & & $13.2 \pm 1.8^{\mathrm{a}}$ & \\
\hline songoramine (31) & & & & $36.4 \pm 5.4^{a}$ & \\
\hline napelline (32) & $14 \pm 5$ & $21 \pm 8$ & $0 \pm 6$ & $10 \pm 8$ & \\
\hline 14-BzA-8-O-laurate (33) & $17 \pm 13$ & $65 \pm 16$ & & $20 \pm 18$ & $52 \pm 25$ \\
\hline 14-BzA-8-O-myristate (34) & $12 \pm 5$ & $25 \pm 9$ & & & \\
\hline 14-BzA-8-O-palmitate (35) & $11 \pm 9$ & $22 \pm 14$ & & $39.6 \pm 5.6^{a}$ & \\
\hline 14-BzA-8-O-stearate (36) & $31 \pm 12$ & $57 \pm 13$ & & $24 \pm 2$ & $43 \pm 13$ \\
\hline 14-BzA-8-O-palmitoleate (37) & $32 \pm 6$ & $76 \pm 4$ & & $20 \pm 16$ & $60 \pm 6$ \\
\hline 14-BzA-8-O-oleate (38) & $14 \pm 14$ & $35 \pm 3$ & & & \\
\hline 14-BzA-8-O- $\gamma$-linolenate (39) & $42 \pm 19$ & $85 \pm 8$ & & $45 \pm 5$ & $92 \pm 3$ \\
\hline 14-BzA-8-O-eicosanoate (40) & $21 \pm 4$ & $47 \pm 6$ & & & \\
\hline 14-BzA-8-O-eicosa-11Z-enoate (41) & $8 \pm 0$ & $17 \pm 9$ & & & \\
\hline 14-BzA-8-O-eicosa-11Z,14Z-dienoate (42) & $18 \pm 8$ & $59 \pm 13$ & & $8 \pm 12$ & $33 \pm 2$ \\
\hline 14-BzA-8-O-eicosa-8Z,11Z,14Z-trienoate (43) & $36 \pm 14$ & $84 \pm 1$ & & $22 \pm 17$ & $46 \pm 19$ \\
\hline
\end{tabular}




\begin{tabular}{lcccc}
\hline & \multicolumn{2}{c}{ GIRK } & hERG \\
& inhibitory activity (\%) & inhibitory activity (\%) \\
\hline 14-BzA-8-O-eicosa-11Z,14Z,17Z-trienoate (44) & $22 \pm 21$ & $78 \pm 15$ & $18 \pm 4$ & $50 \pm 4$ \\
\hline 14-BzA-8-O-eicosa-5Z,8Z,11Z,14Z-tetraenoate (45) & $41 \pm 4$ & $88 \pm 1$ & $37 \pm 12$ & $75 \pm 8$ \\
\hline 14-BzA-8-O-eicosa-5Z,8Z,11Z,14Z,17Z-pentaenoate (46) & $42 \pm 8$ & $91 \pm 1$ & $42 \pm 5$ & $82 \pm 3$ \\
\hline palmitoleic acid (PALO) & $11 \pm 7$ & $36 \pm 7$ & & \\
\hline Y-linolenic acid (g-LIN) & $15 \pm 5$ & $22 \pm 5$ & \\
\hline eicosa-11Z,14Z-dienoic acid (E-DI) & $23 \pm 1$ & $31 \pm 7$ & \\
\hline eicosa-5Z,8Z,11Z,14Z-tetraenoic acid (E-TETR) & $20 \pm 6$ & $17 \pm 16$ & \\
\hline eicosa-5Z,8Z,11Z,14Z,17Z-pentaenoic acid (E-PENT) & $20 \pm 1$ & $13 \pm 19$ & \\
\hline
\end{tabular}

Diterpene alkaloids exerted only moderate activity on GIRK channels. Significant blocking activity on GIRK channel was exerted only by aconitine (18) (45\% in case of $10 \mu \mathrm{M})$ (Fig 10). Similar blocking activity of delcosine (8) and songorine (30) was detected. The tested compounds bearing $C_{18}, C_{19}$ and $\mathrm{C}_{20}$ skeleton, exerted far lower activity on hERG channel than aconitine (18) (Fig 11). Harmful cardiac effects of aconitine are well known [87], however no other aconite alkaloid exerted significantly high inhibition neither on hERG, nor on GIRK channel.

A

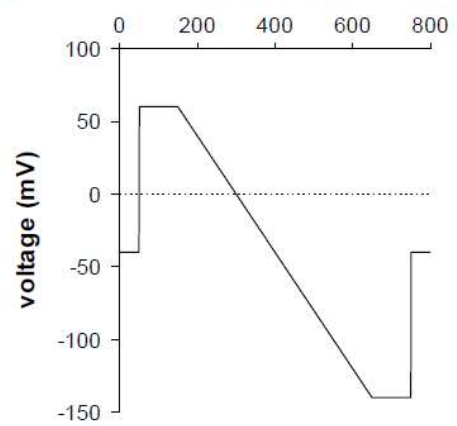

B

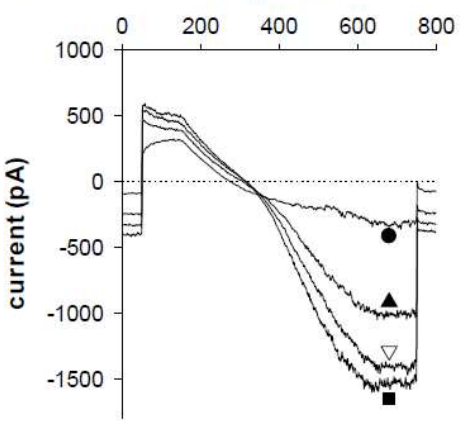

C time (s)

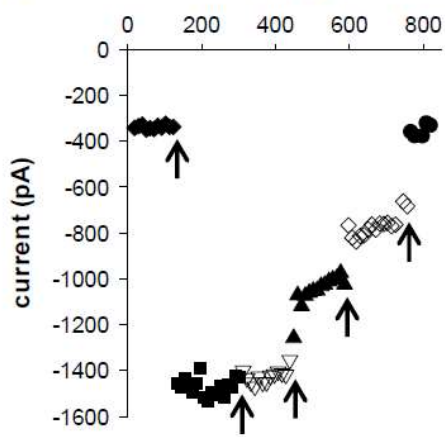

Figure 10. Effect of aconitine (18) on GIRK channel

Panel $\mathbf{A}$ shows the voltage protocol applied during GIRK screen. Effect of the only potent alkaloid (aconitine) is depicted in panel $\mathbf{B}$ and C. Panel B shows typical current curves which were recorded during application of high $\mathrm{K}^{+}$external solution [ $\mathbf{\square}$ ], aconitine (applied concentrations were: $1 \mu \mathrm{M}: \nabla$ and $10 \mu \mathrm{M}: \mathbf{\Delta}$ ) and $\mathrm{K}^{+}$free external solution [0]. Calculated inward currents from the $-140 \mathrm{mV}$ segment of the current sweeps presented on panel $\mathbf{C}$. Arrows indicate exchange of external solution. Elevation of extracellular potassium level from physiological (4 mM: u) to $25 \mathrm{mM}$ [ $\mathbf{\square}$ ] resulted in a well-detectable large increase in GIRK current. Injection of low concentration of aconitine $[1 \mu \mathrm{M}: \nabla]$ did not alter the GIRK current, while application of higher dose $[10 \mu \mathrm{M}: \mathbf{\Delta}]$ resulted in a light but significant inhibition of the current. Injection of reference compound propafenone $[\diamond]$ resulted in a further decrease in GIRK-current. Potassium free external solution [0] served as baseline. 
A

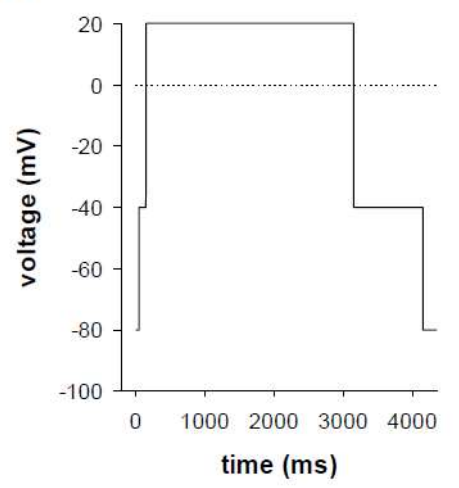

B

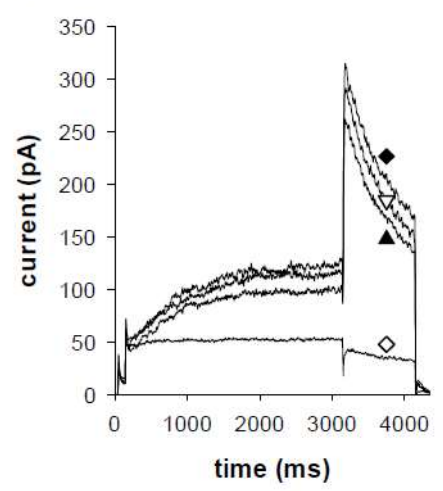

C

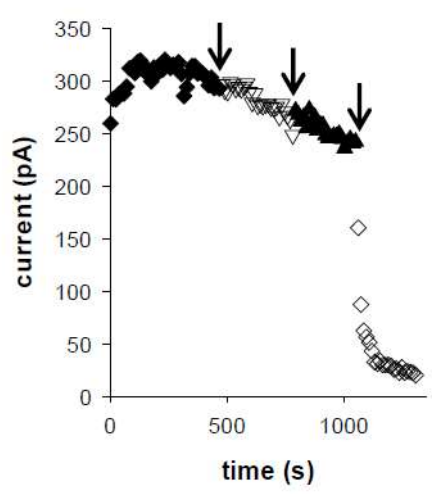

Figure 11. Effect of the non-potent alkaloid napelline (32) on hERG channel

Panel A shows the voltage protocol applied during hERG screen. Effect of napelline is depicted in panel $\mathbf{B}$ and $\mathbf{C}$. Panel $\mathbf{B}$ shows typical current curves which were recorded during application of napelline. Measurement of hERG currents started in external solution [u], followed by the injection of different concentrations of napelline (applied concentrations were: $1 \mu \mathrm{M}: \nabla$ and $10 \mu \mathrm{M}: \mathbf{\Delta}$ ). Amitriptyline $(10 \mu \mathrm{M}: \diamond)$ served as a reference compound. Calculated tail currents from the $-40 \mathrm{mV}$ segments of the current sweeps presented on panel C. Arrows indicate injections of different compounds. Injection of napelline in different concentrations $[1 \mu \mathrm{M}: \nabla$ and $10 \mu \mathrm{M}: \mathbf{\Delta}]$ did not alter the current, while application of reference compound amitriptyline $(10 \mu \mathrm{M}: \diamond)$ resulted in a significant decrease in $\mathrm{hERG}$ current.

All semisynthetic lipo-alkaloids exerted inhibitory activity on the GIRK channel at 1 and $10 \mu \mathrm{M}$ concentrations. The GIRK inhibitory activity of saturated and unsaturated fatty acids was also measured. Free fatty acids were significantly less active than lipo-alkaloids $(33-46)(p<0.05)$ (Fig 12). Lipo-alkaloids exerted significantly higher activity on GIRK channels than diterpene alkaloids (p<0.01) (Fig 13).

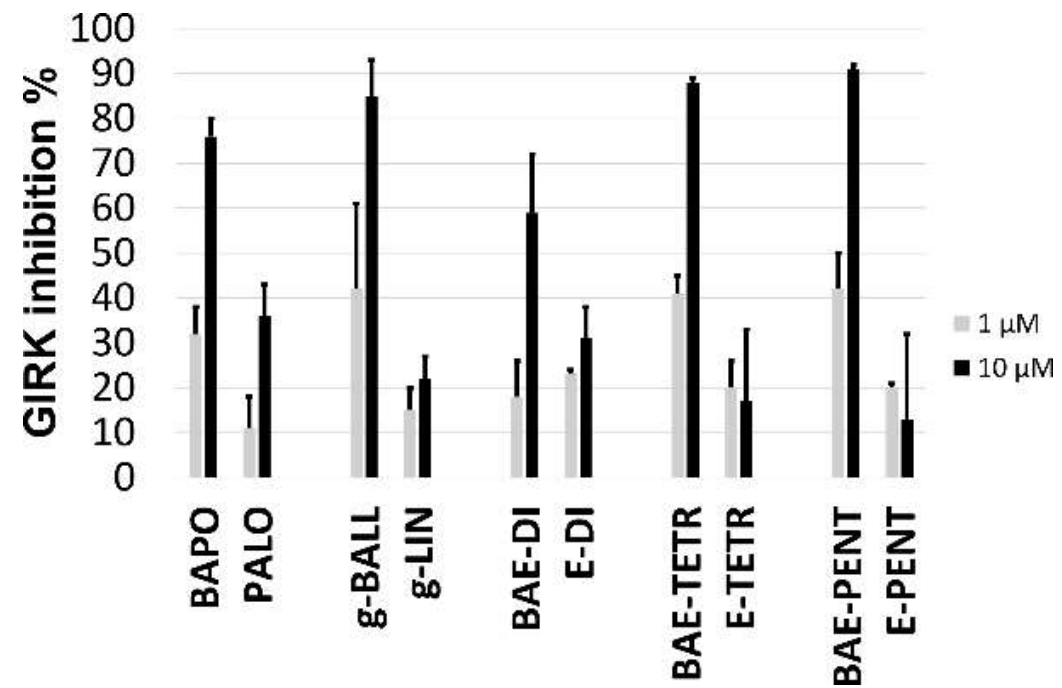

Figure 12. GIRK activities of lipo-alkaloids and their corresponding fatty acids. Values are mean $\pm S D$.

(BAPO: 14-BzA-8-O-palmitoleate (37), PALO: palmitoleic acid, g-BALL: 14-BZA-8-O- - -linolenate (39), g-LIN: $\gamma$-linolenic acid, BAE-DI: 14BzA-8-O-eicosa-11Z,14Z-dienoate (42), E-DI: eicosa-11Z,14Z-dienoic acid, BAE-TETR: 14-BzA-8-O-eicosa-5Z,8Z,11Z,14Z-tetraenoate (45), E-TETR: eicosa-5Z,8Z,11Z,14Z-tetraenoic acid, BAE-PENT: 14-BZA-8-O-eicosa-5Z,8Z,11Z,14Z,17Z-pentaenoate (46), E-PENT: eicosa$5 Z, 8 Z, 11 Z, 14 Z, 17 Z$-pentaenoic acid) 
At $10 \mu \mathrm{M}$ concentration the inhibitory activities of compounds $\mathbf{3 3}, \mathbf{3 7}, \mathbf{3 9}, \mathbf{4 3 - 4 6}$ were higher than 50\%. 14-BzA-O- - -linolenate (39), 14-BzA-8-O-eicosa-5Z,8Z,11Z,14Z-tetraenoate (45) and 14-BzA-8-O-eicosa-5Z,8Z,11Z,14Z,17Z-pentaenoate (46) exerted remarkable activity even at $1 \mu \mathrm{M}$ concentration. Generally, compounds with higher unsaturation degree exerted more potent inhibitory activity, except of compounds having only one or two double bonds. The inhibitory potency increased with the number of double bonds in the order $2<1<3<4<5$. Eicosaenoic acid esters 42-46 were the most effective.

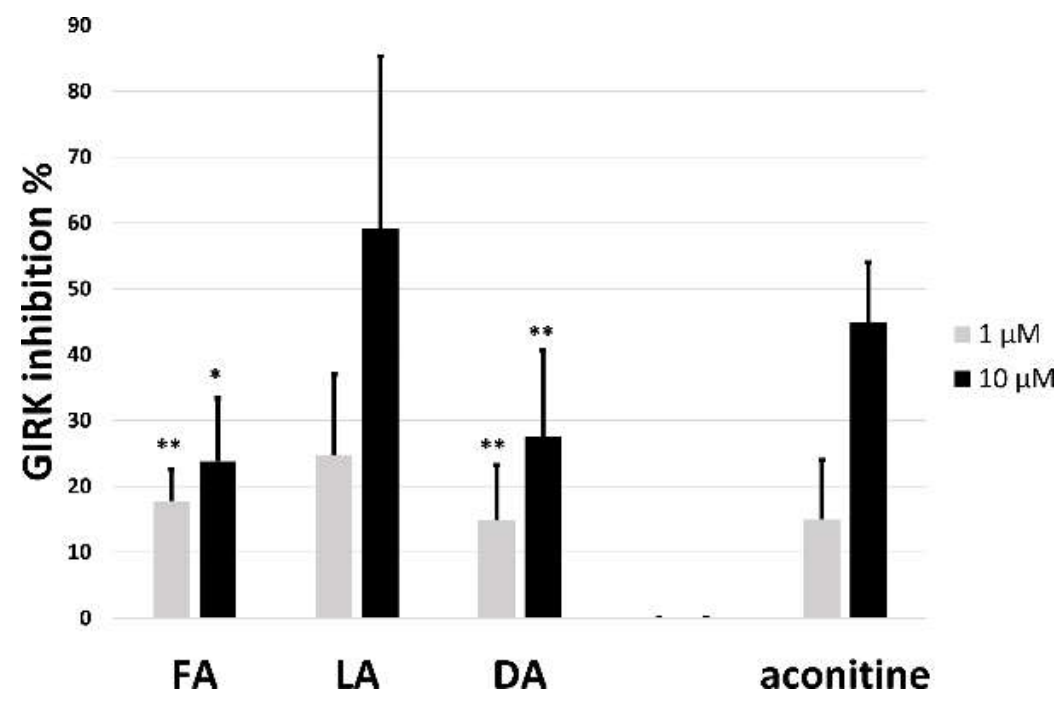

Figure 13. GIRK inhibitory activities of lipo-alkaloids ( $L A, N=14)$ compared to fatty acids $(F A, N=5)$ and diterpene alkaloids (DA, $N=27)$ and aconitine $(N=3)$. Values are mean \pm S.E.M. ${ }^{*} p<0.05,{ }^{* *} p<0.01$

On hERG channels lipo-alkaloids were less active in general than aconitine (Fig 14), however compounds 39 and $\mathbf{4 6}$ are exceptions since their activity is similar to that of aconitine. The compounds with the highest GIRK inhibitory activity are 14-BzA-8-O- $\gamma$-linolenate (39) and 14-BzA-8-O-eicosa-5Z,8Z,11Z,14Z,17Z-pentaenoate (45), however they are also active on hERG channels. Two compounds, 14-BzA-8-O-eicosa-8Z,11Z,14Z-trienoate (43) and 14-BzA-8-O-eicosa-11Z,14Z,17Z-trienoate (44), possess low inhibitory activity on hERG and at the same time they are potent GIRK inhibitors, which renders them worthy of consideration for further pharmacological studies. 


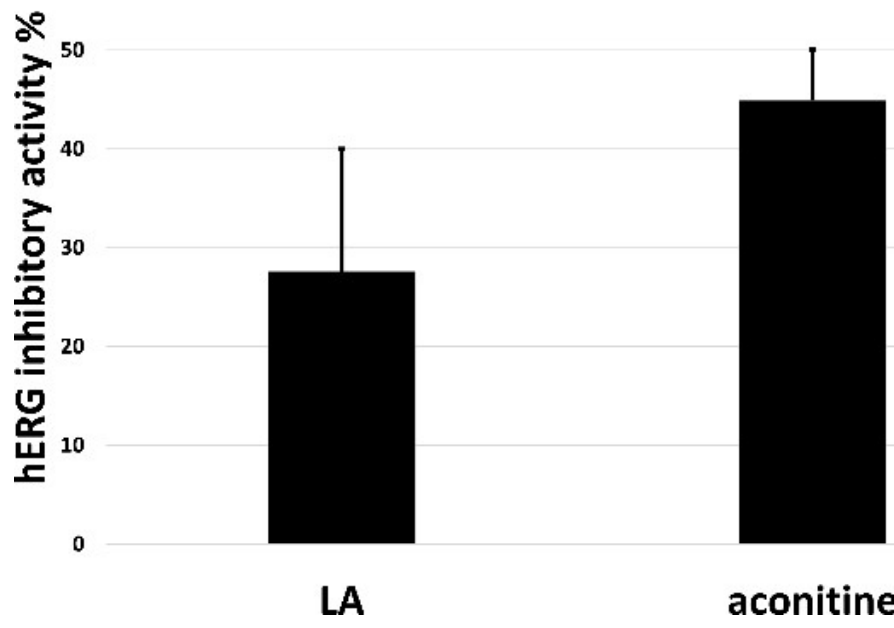

Figure 14. $h E R G$ inhibitory activity of lipo-alkaloids ( $L A$, mean \pm S.E.M., $N=10$ ) compared with aconitine (mean $\pm S D$, $\mathrm{N}=3$ ) at $10 \mu \mathrm{M}$ concentration

\subsubsection{Activity of aconite alkaloids in bdelloid viability assays}

Ten diterpene alkaloids were evaluated for their effects on PA viability (Table 5). All compounds, but napelline (32), increased the toxic survival lifespan value (TSL). Senbusine $A(20)$ and hetisinone (29) resulted in significantly higher TSL assay values (Fig 15A). Most of the compounds (2, 15, 18, 20, 21, 29, 32) increased, while napelline (32) decreased the body size index (BSI) compared to the control group (Fig 15B). The mastax contraction frequency (MFC) was significantly decreased by napelline (32), and increased by aconosine (2) and songorine (30) (Fig 15C). Significantly elevated cellular reduction capacity (CRC) was observed in case of treatment with aconosine (2), aconitine (18), senbusine C (21) and songorine (30), while napelline (32) significantly lowered this value (Fig 15D).
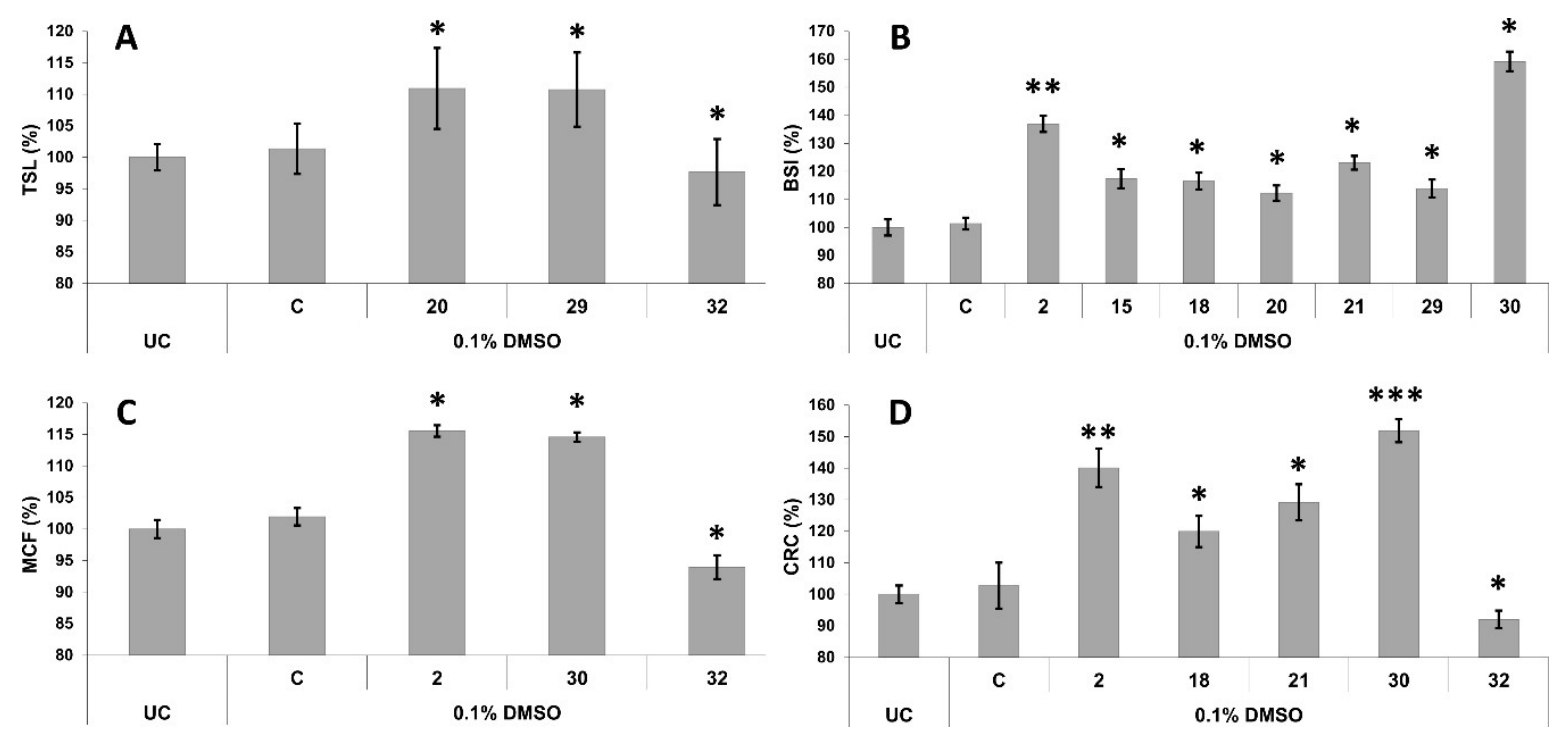

Figure 15. Viability assays on bdelloid rotifers. Values are mean \pm SEM; * $p<0.05 ;^{* *}: p<0.01 ;{ }^{* *}: p<0.001$ 
Table 5. Viability parameters; values are mean $\pm \mathrm{SEM}, \mathrm{N}=32$

\begin{tabular}{lcccc}
\hline Compound & TSL & BSI & MCF & CRC \\
\hline aconosine (2) & $107.1 \pm 5.14$ & $136.9 \pm 2.92$ & $115.5 \pm 0.91$ & $140.1 \pm 6.09$ \\
\hline delavaconitine (4) & $109.8 \pm 6.64$ & $113.9 \pm 3.19$ & $102.6 \pm 1.68$ & $115.9 \pm 6.57$ \\
\hline neoline (15) & $109.3 \pm 7.04$ & $117.4 \pm 3.45$ & $102.0 \pm 2.05$ & $116.7 \pm 3.96$ \\
\hline aconitine (18) & $108.5 \pm 5.18$ & $116.5 \pm 3.00$ & $101.7 \pm 1.78$ & $119.9 \pm 4.96$ \\
\hline senbusine A (20) & $110.9 \pm 6.41$ & $112.2 \pm 2.73$ & $98.9 \pm 2.18$ & $115.5 \pm 5.54$ \\
\hline senbusine C (21) & $107.1 \pm 5.42$ & $123.1 \pm 2.43$ & $101.4 \pm 2.03$ & $129.1 \pm 5.74$ \\
\hline septentriodine (27) & $109.6 \pm 6.12$ & $114.5 \pm 3.05$ & $102.9 \pm 1.79$ & $111.1 \pm 4.79$ \\
\hline hetisinone (29) & $110.7 \pm 5.90$ & $113.9 \pm 3.00$ & $103.9 \pm 1.78$ & $116.4 \pm 6.35$ \\
\hline songorine (30) & $108.4 \pm 6.28$ & $159.2 \pm 3.49$ & $114.6 \pm 0.74$ & $151.8 \pm 3.61$ \\
\hline napelline (32) & $97.6 \pm 5.24$ & $98.7 \pm 2.76$ & $93.9 \pm 1.87$ & $92.0 \pm 2.78$ \\
\hline
\end{tabular}

\subsection{Pharmacological activity of Spiraea chamaedryfolia extracts}

Different fractions were subjected to in vitro antibacterial and XO inhibitory activity screening. The EtOAc fraction was the most potent $\mathrm{XO}$ inhibitor, exerting over $70 \%$ of inhibition compared to allopurinol (Figs 8 and 16). Three fractions exerted antibacterial activity against Staphylococcus aureus (ATCC 29213), Bacillus subtilis (ATCC 6633), Streptococcus pneumoniae (ATCC 49619), Moraxella catarrhalis (ATCC 25238) and one fraction exerted antibacterial activity against methicillin-resistant Staphylococcus aureus (MRSA) (ATCC 43300) (Fig 8 and Table 6).

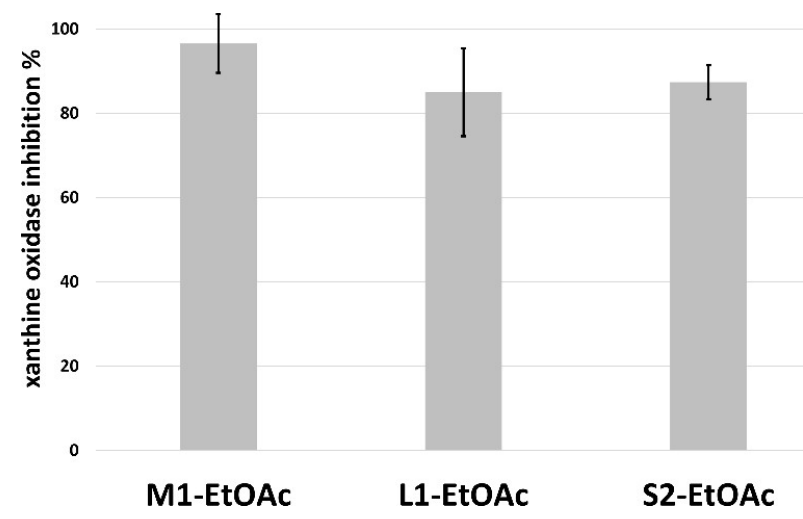

Figure 16. XO inhibitory activity of $S$. chamaedryfolia fractions $(600 \mu \mathrm{g} / \mathrm{mL})$. Values are the mean $\pm S D$

Table 6. Antibacterial activity of $S$. chamaedryfolia fractions $(50 \mathrm{mg} / \mathrm{mL})$; values are the mean $\pm S D$

\begin{tabular}{lccccc}
\hline \multirow{2}{*}{ Fractions } & \multicolumn{5}{c}{ Diameter of inhibition zone (mm) } \\
\cline { 2 - 6 } & $\begin{array}{c}\text { Bacillus } \\
\text { subtilis } \\
\text { ATCC6633 }\end{array}$ & $\begin{array}{c}\text { Staphylococcus } \\
\text { aureus } \\
\text { ATCC } 29213\end{array}$ & $\begin{array}{c}\text { Streptococcus } \\
\text { pneumoniae } \\
\text { ATCC } 49619\end{array}$ & $\begin{array}{c}\text { Moraxella } \\
\text { catarrhalis } \\
\text { ATCC 43617 }\end{array}$ & $\begin{array}{c}\text { Staphylococcus } \\
\text { aureus MRSA } \\
\text { ATCC 43300 }\end{array}$ \\
\hline M1 - EtOAc & $9.6 \pm 0.6$ & $11.3 \pm 1.2$ & $11.7 \pm 1.7$ & $8 \pm 0$ & $11 \pm 0$ \\
\hline L2 - MeOH & - & - & - & $13.7 \pm 0.6$ & - \\
\hline S2 - EtOAC & $12 \pm 0$ & $12.7 \pm 0.6$ & $13 \pm 1$ & $9.3 \pm 0.6$ & $12.6 \pm 0.6$ \\
\hline
\end{tabular}




\subsection{Toxicology of ragweed puree}

\subsubsection{Sesquiterpene lactone content of the product}

Fractions obtained by solid phase extraction were examined by TLC. The sesquiterpene lactones gave specific colour reaction [264]. The richest sesquiterpene lactone content was observed in case of EtOAc fraction. The presence of sesquiterpene lactones, characteristic to ragweed (damsin (203), 3-acetoxydamsin (204), dihydrodamsin (205), hydroxydihydrodamsin (206), paulitin (212), isopaulitin (213), psilostachyin A (214), psilostachyin B (215), psilostachyin C (216)) $[192,196,283,284]$, was confirmed by LC-MS, reassuring the ragweed content of the analysed product.

\subsubsection{Clinical observation and blood chemistry}

There was no remarkable clinical symptom recorded during the observations. The only symptom that appeared in 1-4 animals/group/observational occasion is the lengthened latency time of balance reaction (the rat by head upside down is put onto the lowest part of a grid surface that is inclined in $30^{\circ}$ and the animal has to move upward immediately). However, no statistical significance was seen among groups or between treatment weeks.

Among the biochemical parameters, the activity of liver function enzymes (AST, ALT), the level of triglyceride, carbamide and creatinine were altered significantly in the blood of treated rats. All other laboratory results showed no significant differences.

The activity of liver function enzymes reduced significantly in the low dose treated animals. In the high dose group the reduction was significant only in case of AST (Fig 17A). The level of triglyceride in the blood decreased in the treated rats, which was significant in the low dose group (Fig 17B). The carbamide level showed a dose-related elevation in the treated animals, the change became significant in the high dose ragweed group (Fig 17C). In case of creatinine level, significant difference occurred only between the two ragweed-treated groups (Fig 17D). 


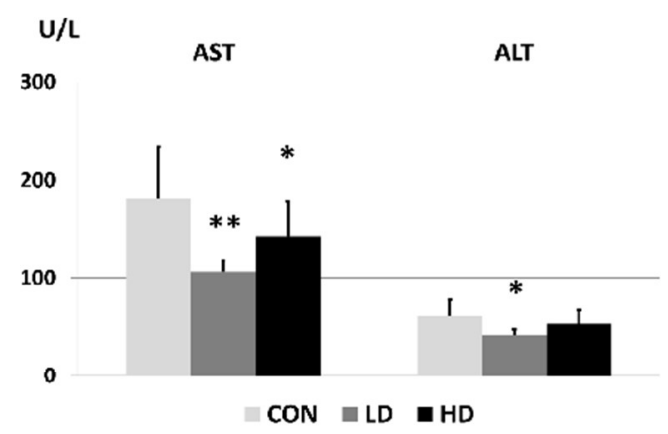

A

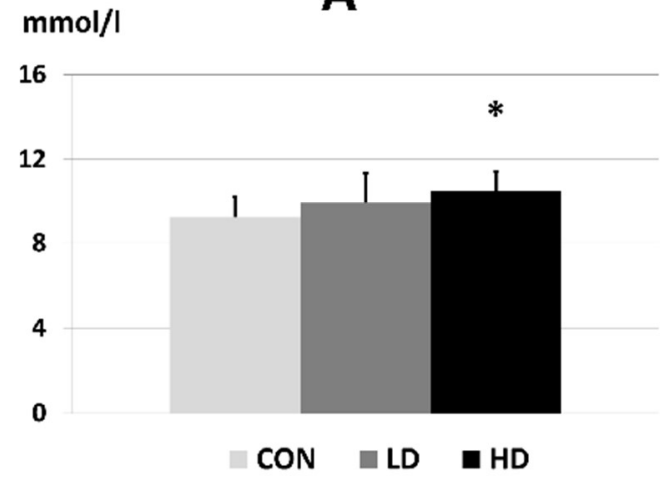

C

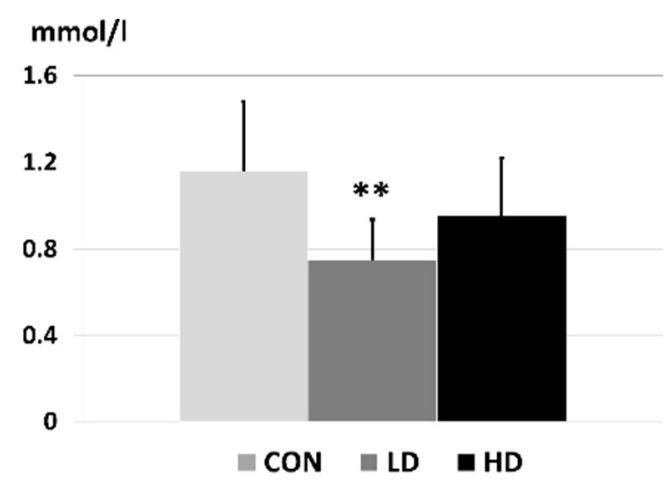

B

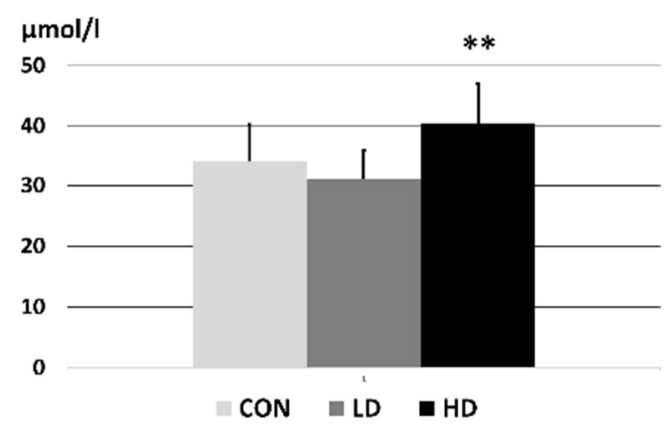

D

Figure 17. Levels of AST and ALT (A), trygliceride (B), carbamide (C) and creatinine (D) in blood serum of the control and treated rats. (CON: control, LD: low dose of ragweed ( $500 \mathrm{mg} / \mathrm{kg} \mathrm{bw),} \mathrm{HD:} \mathrm{high} \mathrm{dose} \mathrm{of} \mathrm{ragweed} \mathrm{(1000} \mathrm{mg/kg} \mathrm{bw);}$ mean SD, $n=8 ; *^{*}: p<0.05, * *: p<0.01$ vs. control)

\subsubsection{General toxicological parameters}

Some weight gain differences were noticed in the treated rats compared to control, but there were no significant differences between the groups over time. The relative organ weights to $100 \mathrm{~g}$ body weight were calculated [271]. The weight of the liver declined with the dose and the difference was statistically significant. The relative weight of brain was significantly increased in both treatment groups compared to the control group.

As the brain weight changed during the treatment, hence the relative organ weights to brain weight were calculated [271]. The relative weight of the liver remained significantly decreased in the treatment groups versus control. The effect on other organ weights was negligible.

By dissection and macroscopic observation of the organs it was found that two animals in the high dose group (animal identification number 20 and 22) had large, pale, smooth, hydronephrotic kidneys with expanded medulla and cortex containing numerous 2-15 mm diameter cysts. For further analysis, these kidneys were sent to a histopathological examination where polycystic kidney disease (PKD) was confirmed. As PKD is caused by genetic mutations both in humans and rats [285], therefore the presence of this disease was excluded from the evaluation 
of the effects of ragweed puree. After this finding the statistical analysis of the parameters affected by the kidneys was re-evaluated by excluding the values of the two affected animals, though the carbamide and creatinine level remained significantly elevated in the high dose group. 


\section{DISCUSSION}

\subsection{Screening and isolation of diterpene alkaloids}

Phytochemical investigation of $A$. napellus subsp. firmum resulted in the isolation of six diterpene alkaloids. Aconitum species are rich sources of diterpene alkaloids, and this group of compounds is considered as chemotaxonomic marker for the genus. However, the variability of the diterpene alkaloid profile could be observed both on the levels of genera and species. The diterpene alkaloid composition detected in our LC-MS experiments shows significant differences from previous results $[286,287]$. The major difference is the lack of mesaconitine and hypaconitine in our sample, two characteristic and widespread alkaloids of the genus (Table 7). Although the isolated compounds are known in A. napellus species [276], the alkaloids napelline (32), isotalatizidine (3), karakoline (19) and senbusine C (21) were obtained for the first time from A. napellus L. subsp. firmum taxon.

Table 7. The alkaloid profile of $A$. napellus subsp. firmum from different harvests

\begin{tabular}{|c|c|c|c|}
\hline & $\begin{array}{l}\text { River Luzhanki } \\
\text { (Ukraina) [286] }\end{array}$ & $\begin{array}{l}\text { Moravskoslezské Beskydy Mount. } \\
\text { (Czech Rep.) [287] }\end{array}$ & $\begin{array}{l}\text { Retezat Mountains } \\
\text { (Romania)* }\end{array}$ \\
\hline neoline & $\mathbf{x}$ & & $\mathbf{x}$ \\
\hline napelline & & & $\mathbf{x}$ \\
\hline isotalatizidine & & & $\mathbf{x}$ \\
\hline karakoline & & & $\mathbf{x}$ \\
\hline senbusine A & $\mathbf{x}$ & & $\mathbf{x}$ \\
\hline senbusine $C$ & & & $\mathbf{x}$ \\
\hline aconitine & & $\mathbf{x}$ & $\mathbf{x}$ \\
\hline taurenine & $\mathbf{x}$ & & $\mathbf{x}$ \\
\hline songorine & $\mathbf{x}$ & & \\
\hline hypaconitine & $\mathbf{x}$ & $\mathbf{x}$ & \\
\hline mesaconitine & $x$ & $\mathbf{x}$ & \\
\hline 3-deoxyaconitine & $\mathbf{x}$ & $\mathbf{x}$ & \\
\hline tadzhaconine & $\mathbf{x}$ & & \\
\hline 15-acetylsongorine & $\mathbf{x}$ & & \\
\hline
\end{tabular}

The ability to synthesise diterpene alkaloids is a unique phenotype outside Ranunculaceae. The number of alkaloid-containing Spiraea species is limited. Among seven investigated Spiraea species, only S. chamaedryfolia contained alkaloid, in S. crenata, S. media, S. salicifolia, S. nipponica, S. $\mathrm{x}$ vanhouttei and S. x billardii, alkaloid content could not be detected. Although the secondary metabolite content is highly affected by environmental conditions, the classification still can possibly rely on chemotaxonomy, taking into consideration the alkaloid content as an easily detectable molecular marker. The examined species were poorly investigated from a 
phytochemical point of view. Chemical compounds have been reported only from S. crenata, $S$. media and S. salicifolia, the other species have not been analysed previously (Table 8).

Table 8. References about the phytochemistry of Spiraea species

\begin{tabular}{lc}
\hline Species & Ref \\
\hline S. crenata & {$[123,288]$} \\
\hline S. media & {$[124,289]$} \\
\hline S. chamaedryfolia & - \\
\hline S. salicifolia & {$[129,135]$} \\
\hline S. nipponica & - \\
\hline S. $x$ vanhouttei & - \\
\hline S. $x$ bilbordii & - \\
\hline
\end{tabular}

\subsection{Biological activities}

\subsubsection{Effects of aconite alkaloids on GIRK and hERG channels}

The ability of diterpene alkaloids to act on cardiac sodium channels is a well-known fact, however the affinity to GIRK and hERG potassium channels have not been investigated in details, yet. Hence, our research group performed screening of diterpene alkaloids (1-32) and 14-benzoyl aconitane lipo-alkaloids (33-46). To understand the role of esterifying fatty acids, five fatty acids were screened.

The bisnor- $\left(C_{18}\right)$, nor- $\left(C_{19}\right)$ and diterpene $\left(C_{20}\right)$ alkaloids substituted with hydroxyl, methoxy, keto, acetyl, veratroyl and benzoyl groups were tested. All of them were $\mathrm{N}$-ethylsubstituted. No selective activity could be observed on GIRK/hERG channels by any of the investigated diterpene alkaloids. Although aconitine (18) was the most potent GIRK inhibitor among investigated diterpene alkaloids, it exerted similar inhibition on hERG channels, as well. These effects are supposed to be the result of the high affinity binding capability of aconitine (18) to the open state of the voltage-sensitive sodium channels, thereby causing a persistent activation of these channels. However, growing body of experimental results demonstrates the blocking capability of aconitine (18) on different potassium channels, e.g. inhibition of hERG and $\mathrm{K}_{\mathrm{v}} 1.5$ potassium channels was reported by Li et al. [102]. hERG blocking effect of aconitine was also proved by our group [105]. The GIRK potassium channel blocking effect of aconitine was reported for the first time by our group. These results suggest a more complex cardiac action of aconitine (18) with a multiple ion channel effect as it was earlier suspected. Other alkaloids of Aconitum did not show any effect neither on GIRK, nor on the hERG channel. 
Lipo-alkaloids exerted inhibitory activity on GIRK channels at both applied concentrations. However, a significant difference between the activity of lipo-alkaloids (33-46), aconitine (18) and free fatty acids (Fig 12) indicates that the 14-BzA-part of the molecule is necessary for the ion channel inhibitory effect (Fig 13). Further structure-activity relationship was recognised concerning the saturation grade of the esterifying fatty acids. The unsaturation of the esterifying fatty acids is a crucial factor for GIRK inhibitory activity (Fig 18).

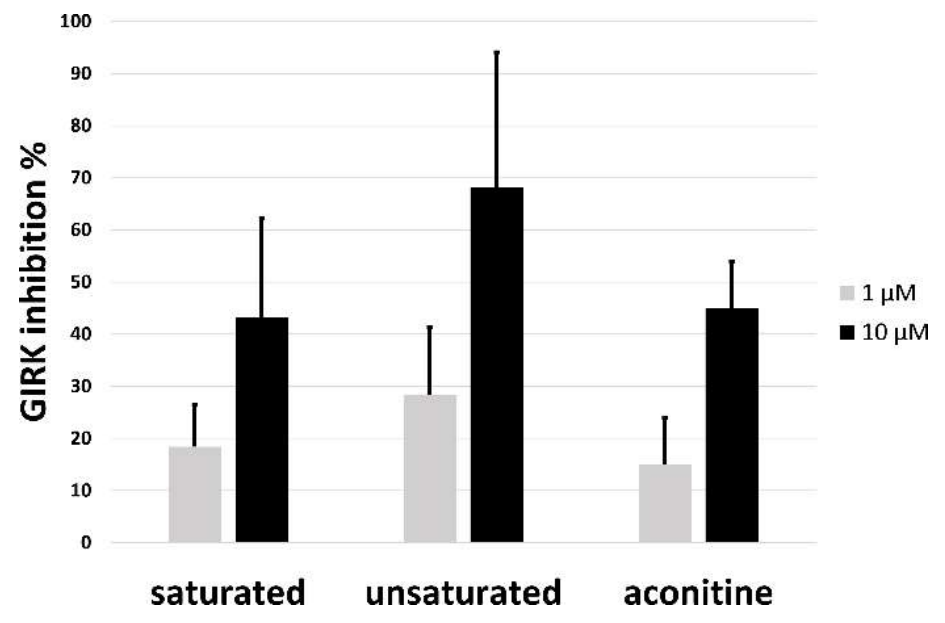

Figure 18. GIRK inhibitory activities of lipo-alkaloids containing saturated $(N=5)$ and unsaturated $(N=9)$ groups. Values are mean \pm SEM

The screening for hERG activity is an important and unavoidable step in order to exclude the cardiotoxicity of the investigated compounds. For the evaluation of compounds with high GIRK activity and low hERG inhibition, GIRK/hERG selectivity was defined as a difference of GIRK and hERG activity. This GIRK/hERG selectivity of compounds belonging to different structural features as shown on Fig 19A. The highest selectivity of lipo-alkaloids is significantly higher than that of diterpene alkaloids ( $p<0.001)$ (Fig 19B).

The hERG activity of two lipo-alkaloids (39 and 46) was similar to aconitine (18). However, these two compounds had noteworthy GIRK activity. Despite this high GIRK inhibitory activity, their hERG activity is raising safety concerns, making them unsuitable for cardiac application. The lipoalkaloids $\mathbf{4 3}$ and $\mathbf{4 4}$ exerted the most beneficial selectivity. They are considered as non cardiotoxic, due to their low hERG activity, however their GIRK inhibition was high, $84 \%$ and $78 \%$, respectively. These results make them worthy of consideration for further pharmacological studies. 

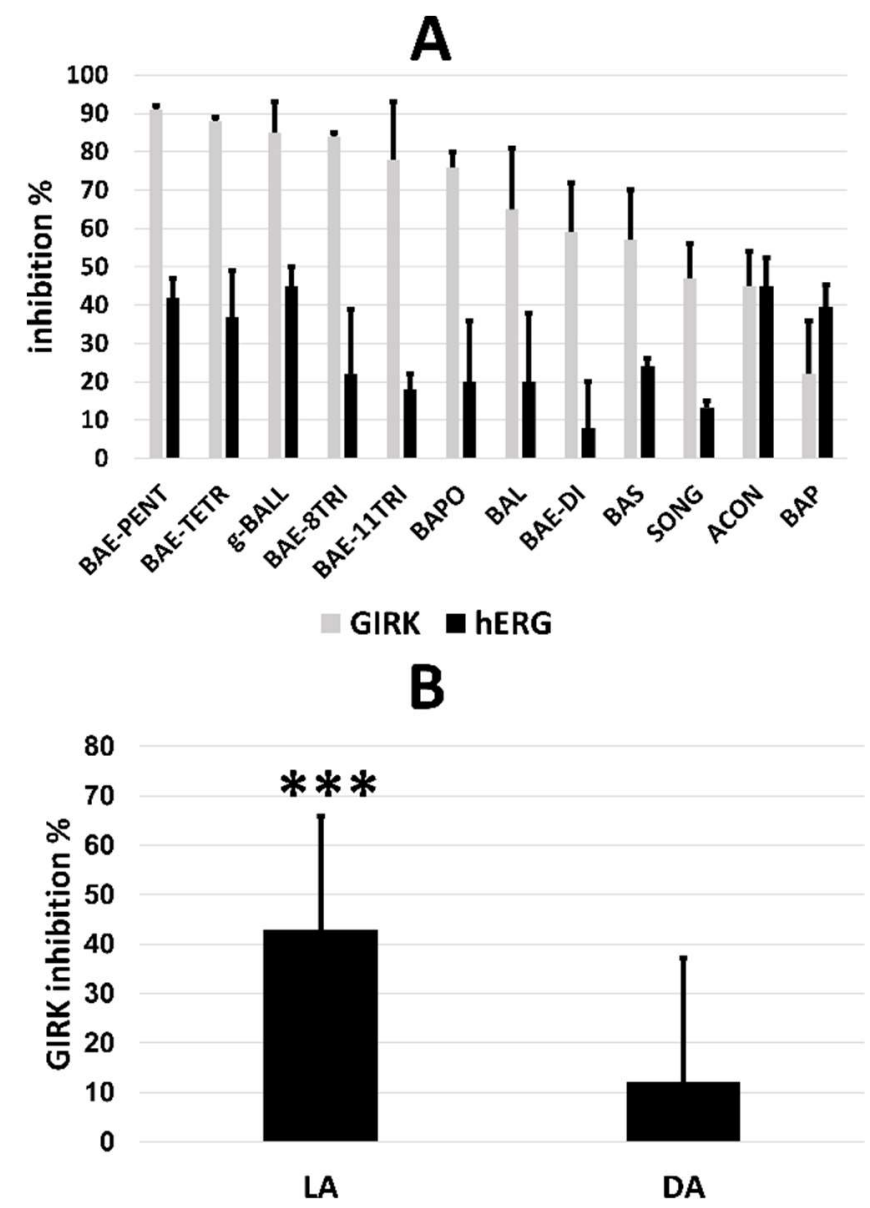

Figure 19. Selectivity of the most potent compounds (A) on the GIRK and $h E R G$ channels $(N=3$, values are the mean \pm SD.) and inhibitory activity of lipo-alkaloids ( $L A$, mean \pm S.E.M., $N=10$ ) and diterpene alkaloids (DA, mean \pm S.E.M., N=25) (B) on GIRK channels at $10 \mu \mathrm{M}$.

(BAE-PENT: 14-BZA-8-O-eicosa-5Z,8Z,11Z,14Z,17Z-pentaenoate, BAE-TETR: 14-BzA-8-0-eicosa-5Z,8Z,11Z,14Z-tetraenoate, g-BALL: 14BzA-8-O- - -linolenate, BAE-8TRI: 14-BzA-8-O-eicosa-8Z,11Z,14Z-trienoate, BAE-11TRI: 14-BzA-8-O-eicosa-11Z,14Z,17Z-trienoate, BAPO: 14-BzA-8-O-palmitoleate, BAL: 14-BzA-8-O-laurate, BAE-DI: 14-BzA-8-O-eicosa-11Z,14Z-dienoate, BAS: 14-BzA-8-O-stearate, SONG: songorine, ACON: aconitine, BAP: 14-BzA-8-O-palmitate).

In summary, the most characteristic compound for the Aconitum genus, aconitine (18), acts both on the hERG and GIRK potassium channels. However, transesterified aconitine-based lipo-alkaloids are selective inhibitors of $\mathrm{K}^{+}$channels, with higher activity on GIRK and lower activity on hERG channels. Fatty acids and diterpene alkaloids exert much lower activity on GIRK channel. These results demonstrate that the diterpene alkaloid skeleton and the aliphatic fatty acid substitution are both prerequisites for GIRK channel inhibition. The most potent compounds are those substituted with polyunsaturated acyl groups. The most selective and thus particularly promising compounds with lowest hERG activity are the newly synthesised 14-BzA-8-O-eicosa8Z,11Z,14Z-trienoate (43) and 14-BzA-8-O-eicosa-11Z,14Z,17Z-trienoate (44). 


\subsubsection{Biological activity of Spiraea chamaedryfolia extracts}

Even though Spiraea species have marginal ethnomedicinal application, previous biological studies have still reported noteworthy results for Spiraea extracts and pure compounds, thus further screenings and examinations are promising.

Six fractions of Spiraea chamaedryfolia were investigated. The in vitro pharmacological screening revealed potential XO inhibitory activity and moderate antibacterial activity. Since no biological activity data of Spiraea chamaedryfolia has been reported previously, our results contribute to the pharmacological profile of this plant.

\subsubsection{Toxicity of diterpene alkaloids on bdelloid rotifers}

Universal aspect of rotifers phenotype was measured to characterize the effects of diterpene alkaloids on the survival, health and behaviour of Philodina acuticornis odiosa. Decrease or increase in the experimental parameters of the rotifers is in correlation with the physiological state of individuals. The aim of these assays was to obtain data on toxicity of diterpene alkaloids. Bdelloid rotifer assays were used for the first time for the investigation of the effects of diterpene alkaloids.

The investigated compounds were non-toxic in these assays, except napelline (32), that reduced all measured parameters. A wide tolerance range for the tested alkaloids - including $\mathrm{C}_{18}$, $\mathrm{C}_{19}$ and $\mathrm{C}_{20}$ diterpene alkaloids - is reported for the first time. This conclusion is supported by the results of toxicity and survival lifespan (TSL), which provides mortality rate, and body size index (BSI). Senbusine A (20) and hetisinone (29) even increased the TSL. Only napelline (32) was toxic by significantly decreasing the lifespan. Most of the investigated alkaloids increased the BSI, except napelline (32) which slightly decreased this value. The mastax contraction frequency values showed no toxicity for investigated compounds, except for napelline (32). In case of aconosine (1) and songorine (10) this parameter was even increased. The cellular reduction capacity gives information about the degree of reduction capacity and oxidative stress triggered by treatment. All compounds elevated cellular reduction capacity, except napelline (32).

Most of the examined compounds have been poorly investigated regarding their toxicity (Table 9). The median lethal dose $\left(L D_{50}\right)$ in mice was available only for compounds $2,4,15,18,30$ and 32. According to these literature data, the most toxic compound is aconitine (18), while songorine (30) is the least toxic. The weak toxicity of songorine (30) is also supported by our experiment. The well-known aconitine (18) possesses high toxicity in vivo both in rodents and mammalians [6]. However, in our assay, napelline (32) showed to be the most toxic. Since there were no toxicity data for compound $\mathbf{2 0}, \mathbf{2 1}, \mathbf{2 7}$ and $\mathbf{2 9}$, here we report their in vivo toxicity results for the first time. 
Table 9. $\mathrm{LD}_{50}$ data for the investigated compounds reported in literature (NA: not available, [290]a,d; [291]a,f; [6]c; [292]e)

\begin{tabular}{|c|c|c|c|c|}
\hline \multirow[t]{2}{*}{ Compound } & \multicolumn{4}{|c|}{$\mathrm{LD}_{50}(\mathrm{mg} / \mathrm{kg})$} \\
\hline & oral & intravenous & subcutaneous & intraperitoneal \\
\hline aconosine (2) & NA & NA & NA & $154^{a}$ \\
\hline delavaconitine (4) & NA & $28.5^{b}$ & $106^{b}$ & NA \\
\hline aconitine (18) & $1.0^{c}$ & $0.10^{c}$ & $0.27^{c}$ & $0.27^{c}$ \\
\hline neoline (15) & NA & NA & NA & $150^{d}$ \\
\hline senbusine A (20) & NA & NA & NA & NA \\
\hline senbusine C (21) & NA & NA & NA & NA \\
\hline septentriodine (27) & NA & NA & NA & NA \\
\hline hetisinone (29) & $\mathrm{NA}$ & NA & NA & NA \\
\hline songorine (30) & $1575^{a}$ & $142.5^{e}$ & $630^{e}$ & $485^{e}$ \\
\hline napelline (32) & NA & $88^{a}$ & NA & NA \\
\hline
\end{tabular}

In summary, this in vivo screening system, with four different methods, made it possible to measure various conditions at different sensitivity levels of detection independently and/or simultaneously, providing a reliable and highly replicable screening method in pharmaceutical science.

\subsubsection{Toxicological evaluation of common ragweed}

The study design and the special feeding technique were proven successful in rats which can be eligible to model the effects of oral ragweed puree consumption in humans. Four weeks of treatment evoked no visible clinical symptom but was enough to induce some laboratory alterations that raise concern.

AST and ALT are considered two of the most important enzymes that indicate liver injury. Generally increased AST and ALT levels are associated with liver cell damage [293]; during the destruction of liver cells a peak in AST and ALT elevation occurs, but as the process progresses, enzyme levels may decrease even to the normal level [294]. In our study decreased enzyme levels were observed in the LD group, which may implicate a developing liver atrophy. This correlates with the observed reduction of relative liver weight. Although no macroscopic alteration could be observed in the liver tissue, further experiments are required, since no histological studies were performed previously.

According to an earlier investigation, ragweed treatment may also have hepatoprotective effects, since in that case the normalization of ALT and AlkP activity and blood bilirubin level were observed. In that experiment polyphenol-rich fraction, isolated from Ambrosia was applied in a model of acute toxic hepatic damage caused by carbon tetrachloride in rats [182].

Parkhomenko et al. observed hypolipaemic properties of polyphenolic fractions isolated from common ragweed in rats after inducing hyperlipidaemia by the joint per oral administration of vitamin $D_{2}$ and cholesterol [182]. Their results are in agreement with the documented triglyceride level reduction in our study. 
Nephrotoxicity can be associated with a temporary elevation of laboratory values like carbamide, reflecting less carbamide being filtered through the kidneys. In our study, the elevated carbamide levels were measured after ragweed treatment, which is a clear sign of kidney damage. In the study of Noori et al. Wistar rats were injected with an ethanolic extract of Artemisia deserti Krasch. (species related to $A$. artemisiifolia). The extract produced histopathological alterations in the kidneys of rats. The serum carbamide level was elevated, but the change was not significant [295]. Levels of urea were increased significantly and kidney tissue damage was observed in the treated groups compared to control group in the experiment of Ene-ojo et al. [296]. However, we also evaluated the changes in creatinine levels and a similar trend was observed, but the change was significant only between the LD and HD groups.

Sesquiterpene lactones, found mainly in the Asteraceae family, may play a significant role in the toxic effects of ragweed on animal organs. Nephrotoxic effects of sesquiterpene lactonecontaining herbal extracts have been reported in previous studies. The most widely known Asteraceae plant for its nephrotoxic effect is Hymenoxys odorata. Ingestion of this plant results in complex toxic symptoms, including glomerulonephrosis and hepatotoxicity - reported in sheep and goats [297]. Parthenin, a compound characteristic to Parthenium species, inhibited RNA, DNA and protein synthesis in vitro in cultured bovine kidney cells [298]. In a repeated dose toxicity study in rats, the administration of sesquiterpene lactone containing extracts of Smallanthus sonchifolius resulted in alterations of creatinine, glucose and albumin levels, implying renal damage. Histological analysis showed lesions compatible with chronic glomerulonephrosis [299]. Similar nephrotoxicity, together with the signs of hepatotoxicity was observed in an acute toxicity study carried out on rats with the ethanolic extract of Tithonia diversifolia, a species belonging to Asteraceae with confirmed sesquiterpene lactone content [300]. However, some sesquiterpene lactones may have hepatoprotective effects: an enriched fraction of sesquiterpene lactones of Taraxacum officinale roots exerted protective effect against carbon tetrachloride-induced hepatotoxicity in mice [301]. Certain sesquiterpene lactones of Sarcandra glabra showed hepatoprotective activity against Dgalactosamine-induced toxicity in WB-F344 rat hepatic epithelial cells in vitro [302].

Observations on livestock lead to the recognition that some sesquiterpene lactones are responsible for pharmacological effects on the central nervous system. Symptoms similar to Parkinson's disease occurred in horses after long term feeding of Centaurea solstitialis and $C$. repens. This disease - nigropallidal encephalomalacia - is characterized by liquefactive necrosis on various parts of the brain [303].

Another group of sesquiterpene lactones exerted neurotoxic activity by acting on GABA and glycine receptors as antagonists [297]. However, there are no data on the effect of sesquiterpene lactones on the brain weight. As organ weight change often precedes morphological alterations 
[304], our results draw attention to this possible effect, however, there is no evidence that the observed change in brain weight is linked to the sesquiterpenes of ragweed.

Our results refer to nephrotoxicity of common ragweed and its controversial effect on brain tissue. These results are in line with previous studies carried out with some other species of the genus Artemisia and with the Asteraceae family. The mechanism by which ragweed constituents affect different organs cannot be derived from the present study, the reason for these toxic effects remains to be clarified. 


\section{SUMMARY}

The aim of this study was the phytochemical, pharmacological and toxicological evaluation of diterpene alkaloid-containing species (Aconitum napellus subsp. firmum, S. chamaedryfolia S. crenata, S. media, S. salicifolia, S. nipponica, S. x vanhouttei and S. $x$ billardii) and the sesquiterpene lactone-containing Ambrosia artemisiifolia.

Six diterpene alkaloids [neoline (AF1; 15), napelline (AF2; 32), isotalatizidine (AF3; 6), karakoline (AF4; 19), senbusine A (AF5; 20), senbusine C (AF6; 21)] were isolated and further two alkaloids [aconitine (AF7; 18) and taurenine (AF8; 22)] were detected from A. napellus subsp. firmum, four of them (AF2-AF4, AF6) were reported for the first time. The screening of seven Spiraea species resulted in the identification of alkaloids presence in Spiraea chamaedryfolia.

Diterpene alkaloids and lipo-alkaloids were examined for their activity on cardiac potassium channels. Aconitine (18) exerted noteworthy activity on hERG and GIRK channels. Our results suggest more complex cardiac action with a multiple ion channel effect for aconitine (18) than it was earlier suspected. Investigation of activities of fourteen lipo-alkaloids on GIRK and hERG afforded the recognition of structure-activity relationships. Lipo-alkaloids are significantly better GIRK inhibitors than diterpene-alkaloids and free fatty acids. The higher unsaturation grade of acyl groups resulted in higher activity on GIRK channels. Two compounds, namely 14-BzA-8-O-eicosa-8Z,11Z,14Z-trienoate (43) and 14-BzA-8-O-eicosa-11Z,14Z,17Z-trienoate (44) had optimal selectivity, with the highest activity on GIRK ( $>75 \%$ at $10 \mu \mathrm{M}$ concentration) and lowest activity on hERG (<22\%) channels.

Fractions of Spiraea chamaedryfolia with different polarity exerted noteworthy XO inhibitory activity $(>70 \%)$ and moderate antibacterial activity. The performed pharmacological study was the first investigation on the biological activity of S. chamaedryfolia.

Toxicity of diterpene alkaloids and common ragweed-containing puree was examined. Ten diterpene alkaloids were evaluated using bdelloid rotifer assays, four of which (senbusine A (20), senbusine C (21), septentriodine (27) and hetisinone (29)) were examined for their toxicological properties for the first time. The adventive and invasive Ambrosia artemisiifolia-containing puree was analyzed in vivo in rats. The study ended without any visible clinical symptoms, however the relative liver- and brain-weight was significantly reduced. The analysed blood parameters (AST, ALT liver enzymes, triglyceride and carbamide level) were significantly changed. The reduction of liver enzymes with reduced relative liver weight, reduction of relative brain weight, together with elevated level of carbamide indicated a toxic effect. According to our results, the repeated use of ragweed resulted in toxic effects in rats and these results query the safety of long-term human consumption of the plant. 
In summary, the results of our experimental work clearly point out the necessity of phytochemical and toxicological evaluation of medicinal plants. The well-known and thoroughly investigated Aconitum species proved to be still a source of new pharmacons. The effects and side effects of Aconitum have been recognised, due to extensive pharmacological studies, which described the activity of aconite compounds on cardiac potassium channels. Hence, the traditional medicinal applications are raising new safety concerns. Plants, newly involved in phytotherapy, are lacking experiences from traditional applications, thus the consequences of long-term consumption cannot be specified. Toxicological investigations are useful tools in clarification of safety issues. Common ragweed-containing puree, as a novel food, showed to be toxic in rats, thus long-term human use supposed to be not safe. 


\section{REFERENCES}

[1] D.J. Newman, G.M. Cragg, J. Nat. Prod. 79 (2016) 629-661.

[2] B. Shen, Cell 163 (2015) 1297-1300.

[3] D. Shaw, L. Graeme, D. Pierre, W. Elizabeth, C. Kelvin, J. Ethnopharmacol. 140 (2012) 513-518.

[4] F. Stickel, H.K. Seitz, Public Health Nutr. 3 (2000) 501-8.

[5] P. Orvos, L. Virág, L. Tálosi, Z. Hajdú, D. Csupor, N. Jedlinszki, T. Szél, A. Varró, J. Hohmann, Fitoterapia 100 (2015) 156-165.

[6] J. Singhuber, M. Zhu, S. Prinz, B. Kopp, J. Ethnopharmacol. 126 (2009) 18-30.

[7] Y. Bai, H.K. Desai, S.W. Pelletier, J. Nat. Prod. 57 (1994) 963-970.

[8] B. Borcsa, D. Csupor, P. Forgo, U. Widowitz, R. Bauer, J. Hohmann, Nat. Prod. Commun. 6 (2011) 527-36.

[9] M. El-Shazly, C.-J. Tai, T.-Y. Wu, D. Csupor, J. Hohmann, F.-R. Chang, Y.-C. Wu, J. Food Drug Anal. 24 (2016) 2945.

[10] Directive 2004/24/EC of the European Parliament and of the Council of 31 March 2004 Amending, as Regards Traditional Herbal Medicinal Products, Directive 2001/83/EC on the Community Code Relating to Medicinal Products for Human Use, European Parliament and European Council, 2004.

[11] M. Tamura, Acta Phytotax Geobot 41 (1990) 93-101.

[12] Y. Luo, F. Zhang, Q.-E. Yang, Plant Syst. Evol. 252 (2005) 11-25.

[13] T. Tutin, J. Akeroyd, A. Chater, in: T. Tutin, N. Burges, A. Chater, J. Edmondson, V. Heywood, D. Moore, D. Valentine, S. Walters, D. Webb (Eds.), Flora Eur., University Press, Cambridge, 2005, pp. 245-257.

[14] L. Lingdi, C. Alexander, Flora of China 9 (2003) 47-73.

[15] G. Khan, F.-Q. Zhang, Q.-B. Gao, P.-C. Fu, R. Xing, J.-L. Wang, H.-R. Liu, S.-L. Chen, Plant Syst. Evol. 302 (2016) 1121.

[16] J. Dostal, in: T.G. Tutin (Ed.), Flora Eur. Rosaceae, to Umbelliferae, University Press, Cambridge, 1968, pp. 4-6.

[17] D. Potter, S.M. Still, T. Grebenc, D. Ballian, G. Božič, J. Franjiæ, H. Kraigher, Plant Syst. Evol. 266 (2007) 105-118.

[18] D. Bartha, R. Vidéki, A. Máté, Flora Pannonica 2 (2004) 119-127. (In Hungarian)

[19] G. Király, ed., Új Magyar Füvészkönyv, Aggteleki Nemzeti Par Igazgatóság, 2009. (In Hungarian)

[20] S. Farkas, ed., Magyarország Védett Növényei, Mezőgazda Kiadó, Budapest, 1999. (In Hungarian)

[21] S. Rutkovska, I. Pučka, I. Novicka, in: Environ. Technol. Resour. Proc. 8th Int. Sci. Pract. Conf., Latvia, 2011, pp. 344-351.

[22] G. Kazinczi, I. Béres, R. Novák, K. Bíró, Z. Pathy, Herbologia 9 (2008) 55-91.

[23] W.W. Payne, Brittonia 18 (1966) 28.

[24] E. Gerber, U. Schaffner, A. Gassmann, H.L. Hinz, M. Seier, H. Müller-Schärer, Weed Res. 51 (2011) 559-573.

[25] C. Szigetvári, Z.R. Benkő, in:, B. Mihály, Z. Botta-Dukát (Eds.), Özönnövények - Biológiai Inváziók Magyarországon., TermészetBúVÁR Alapítvány Kiadó, Budapest, 2004, pp. 337-370. (In Hungarian)

[26] F. Wan, R. Wang, J. Ding, in:, E.S. Delfosse, R.R. Scott (Eds.), Proc. Eigth Int. Symp. Biol. Control Weeds, Melbourne, 1995, pp. 193-200.

[27] H.P. Duan, B.L. Chen, Acta Agric. Shanghai 16 (2000) 73-77. (In Chinese)

[28] F. Essl, K. Biró, D. Brandes, O. Broennimann, J.M. Bullock, D.S. Chapman, B. Chauvel, S. Dullinger, B. Fumanal, A. Guisan, G. Karrer, G. Kazinczi, C. Kueffer, B. Laitung, C. Lavoie, M. Leitner, T. Mang, D. Moser, H. Müller-Schärer, B. Petitpierre, R. Richter, U. Schaffner, M. Smith, U. Starfinger, R. Vautard, G. Vogl, M. von der Lippe, S. Follak, J. Ecol. 103 (2015) 1069-1098.

[29] DAISE, Evaluation by the delivering alien invasive species inventories for Europe, http://www.europe-aliens.org/speciesTheWorst.do (10/06/2016).

[30] ISSG, Ambrosia artemisiifolia (herb) (2010) http://www.issg.org/database/species/ecology.asp?si=1125 (10/06/2016).

[31] S. Cunze, M.C. Leiblein, O. Tackenberg, ISRN Ecol. 2013 (2013) 1-9.

[32] P. Wayne, S. Foster, J. Connolly, F. Bazzaz, P. Epstein, Ann. Allergy. Asthma Immunol. 88 (2002) 279-282.

[33] A. El Kelish, F. Zhao, W. Heller, J.J. Durner, J.B. Winkler, H. Behrendt, C. Traidl-Hoffmann, R. Horres, M. Pfeifer, U. Frank, D. Ernst, BMC Plant Biol. 14 (2014) 176.

[34] F. Zhao, A. Elkelish, J.J. Durner, C. Lindermayr, J.B. Winkler, F. Rueff, H. Behrendt, C. Traidl-Hoffmann, A. Holzinger, W. Kofler, P. Braun, C. von Toerne, S.M. Hauck, D. Ernst, U. Frank, Plant. Cell Environ. 39 (2016) 147164.

[35] Pharmacopoeia of the People's Republic of China. Vol. I., People's Medical Publishing House, Beijing, 2005.

[36] Y. Jaiswal, Z. Liang, P. Yong, H. Chen, Z. Zhao, Chem. Cent. J. 7 (2013) 169.

[37] J.M. Rawat, B. Rawat, A. Bhandari, S. Yadav, S. Mishra, A. Chandra, S. Mishra, Acta Physiol. Plant. 38 (2016) 280.

[38] T.-H. Lee, Y.-C. Chen, C.-K. Lee, H.-S. Chang, C.-C. Kuo, C.-Y. Chao, J.-J. Lin, L.-C. Lo, Y.-H. Kuo, Nat. Prod. Commun. 8 (2013) 827-828.

[39] J. Li, H. Chang, W. Zhao, H. Pi, H. Ruan, P. Zhang, Helv. Chim. Acta 97 (2014) 689-693.

[40] X. Qin, S. Yang, Y. Zhao, Y. Gao, F. Ren, D. Zhang, F. Wang, Chem. Nat. Compd. 53 (2017) 501-503.

[41] S.-Y. Zhang, Y. Jiang, Y.-F. Bi, W.-J. Yan, Y.-B. Zhang, J. Asian Nat. Prod. Res. 15 (2013) 78-83. 
[42] B. Xu, J. Xue, J. Tan, S. Jiang, F. Guo, Y. Li, Helv. Chim. Acta 97 (2014) 727-732.

[43] Q. Zhang, J.-J. Tan, X.-Q. Chen, Z.-B. Gao, Q. Jia, K.-X. Chen, Y.-M. Li, Tetrahedron Lett. 58 (2017) 1717-1720.

[44] D.-K. Zhao, H.-L. Ai, S.-H. Zi, L.-M. Zhang, S.-C. Yang, H.-C. Guo, Y. Shen, Y.-P. Chen, J.-J. Chen, Fitoterapia 91 (2013) 280-283.

[45] J.-J. Xu, D.-K. Zhao, H.-L. Ai, L.-M. Zhang, S.-Q. Xie, S.-H. Zi, S.-C. Yang, Y. Shen, Helv. Chim. Acta 96 (2013) 21552159.

[46] G.-Q. Li, L.-M. Zhang, D.-K. Zhao, Y.-P. Chen, Y. Shen, J. Asian Nat. Prod. Res. 19 (2017) 457-461.

[47] X.-X. Zong, G. Yan, J.-L. Wu, E.L.-H. Leung, H. Zhou, N. Li, L. Liu, Tetrahedron Lett. 58 (2017) 1622-1626.

[48] X. Qin, S. Yang, Y. Zhao, Y. Gao, F. Ren, D. Zhang, F. Wang, Phytochem. Lett. 13 (2015) 390-393.

[49] T.-P. Yin, L. Cai, H. Zhou, X.-F. Zhu, Y. Chen, Z.-T. Ding, Nat. Prod. Res. 28 (2014) 1649-1654.

[50] T.-P. Yin, L. Cai, J.-M. He, J.-W. Dong, H.-X. Fang, H. Zhou, Z.-T. Ding, J. Asian Nat. Prod. Res. 16 (2014) 345-350.

[51] D.-K. Zhao, X.-Q. Shi, L.-M. Zhang, D.-Q. Yang, H.-C. Guo, Y.-P. Chen, Y. Shen, Chinese Chem. Lett. 28 (2017) 358361.

[52] X. Liang, L. Chen, L. Song, W. Fei, M. He, C. He, Z. Yin, Nat. Prod. Res. 31 (2017) 2016-2023.

[53] T.-P. Yin, L. Cai, Y. Li, Y.-S. Fang, L. Peng, Z.-T. Ding, Nat. Products Bioprospect. 5 (2015) 271-275.

[54] S. Begum, M. Ali, A. Latif, W. Ahmad, S. Alam, M. Nisar, M. Zeeshan, M.T.H. Khan, F. Shaheen, M. Ahmad, Rec. Nat. Prod. 8 (2014) 83-92.

[55] F. Wang, Z. Yue, P. Xie, L. Zhang, Z. Li, B. Song, Z. Tang, X. Song, Molecules 21 (2016) 1175.

[56] Z.-J. Guo, Y. Xu, H. Zhang, M.-Y. Li, K. Xi, Nat. Prod. Res. 28 (2014) 164-168.

[57] T.-P. Yin, L. Cai, H.-X. Fang, Y.-S. Fang, Z.-J. Li, Z.-T. Ding, Phytochemistry 116 (2015) 314-319.

[58] L. Cai, H. Fang, T. Yin, J. Yu, Z. Li, J. Dong, Z. Ding, Phytochem. Lett. 14 (2015) 106-110.

[59] Y. Liang, J.-L. Wu, X. Li, M.-Q. Guo, E.L.-H. Leung, H. Zhou, L. Liu, N. Li, Tetrahedron Lett. 57 (2016) 5881-5884.

[60] X.-H. Meng, Z.-B. Jiang, Q.-L. Guo, J.-G. Shi, Chinese Chem. Lett. 28 (2017) 588-592.

[61] L.-G. Yang, Y.-J. Zhang, J.-Y. Xie, W.-J. Xia, H.-Y. Zhang, M.-Y. Tang, S.-X. Mei, T. Cui, J.-K. Wang, Z.-Y. Zhu, J. Asian Nat. Prod. Res. 18 (2016) 908-912.

[62] J. Yu, T.-P. Yin, J.-P. Wang, R.-F. Mei, L. Cai, Z.-T. Ding, Nat. Prod. Res. 31 (2017) 228-232.

[63] S. Li, J. Xiong, Y. Zhang, Q. Xiang, F. Chen, Nat. Prod. Commun. 8 (2013) 155-156.

[64] B.-N. Xing, S.-S. Jin, H. Wang, Q.-F. Tang, J.-H. Liu, R.-Y. Li, J.-Y. Liang, Y.-Q. Tang, C.-H. Yang, Fitoterapia 94 (2014) 120-126.

[65] L. Chen, L. Shan, W. Xu, J. Zhang, S. Huang, X. Zhou, Nat. Prod. Res. 31 (2017) 523-528.

[66] H. Tang, F.-L. Wen, S.-H. Wang, X.-Y. Liu, D.-L. Chen, F.-P. Wang, Chinese Chem. Lett. 27 (2016) 761-763.

[67] Z.-T. Zhang, X.-Y. Liu, D.-L. Chen, F.-P. Wang, Nat. Prod. Commun. 10 (2015) 861-2.

[68] T.-X. Tang, Q.-F. Chen, X.-Y. Liu, X.-X. Jian, F.-P. Wang, J. Asian Nat. Prod. Res. 18 (2016) 315-327.

[69] B.-L. Ji, L.-P. Xia, F.-X. Zhou, G.-Z. Mao, L.-X. Xu, Eur. Rev. Med. Pharmacol. Sci. 20 (2016) 4955-4964.

[70] M. Liang, J. Liu, H. Ji, M. Chen, Y. Zhao, S. Li, X. Zhang, J. Li, Tumor Biol. 36 (2015) 7085-7091.

[71] Y. V Nesterova, T.N. Povet'yeva, N.I. Suslov, G.N. Zyuz'kov, S. V Pushkarskii, S.G. Aksinenko, E.E. Schultz, S.S. Kravtsova, A. V Krapivin, Bull. Exp. Biol. Med. 157 (2014) 488-491.

[72] M.-Y. Ren, Q.-T. Yu, C.-Y. Shi, J.-B. Luo, Molecules 22 (2017) 267.

[73] M.A. Turabekova, B.F. Rasulev, F.N. Dzhakhangirov, A.A. Toropov, D. Leszczynska, J. Leszczynski, J. Environ. Sci. Heal. Part C 32 (2014) 213-238.

[74] Y. V Nesterova, T.N. Povetieva, N.I. Suslov, G.N. Zyuz'kov, S.G. Aksinenko, S. V Pushkarskii, A. V Krapivin, Bull. Exp. Biol. Med. 156 (2014) 665-668.

[75] X. Li, J. Jiang, S. Shi, S.W.A. Bligh, Y. Li, Y. Jiang, D. Huang, Y. Ke, S. Wang, PLoS One 9 (2014) e99697.

[76] Y. V Nesterova, T.N. Povet'eva, N.I. Suslov, E.E. Shults, G.N. Ziuz'kov, S.G. Aksinenko, O.G. Afanas'eva, A. V Krapivin, T.G. Kharina, Bull. Exp. Biol. Med. 159 (2015) 620-622.

[77] Y. V Nesterova, T.N. Povet'eva, N.I. Suslov, S.G. Aksinenko, E.E. Shul'ts, O.G. Afanas'eva, A. V Krapivin, G.N. Zyuz'kov, Pharmacological Agent with Anxiolytic Activity., 2015 (Patent: RU 2571286 C1 20151220, In Russian).

[78] I. Kitagawa, M. Yoshikawa, Z.L. Chen, K. Kobayashi, Chem. Pharm. Bull. (Tokyo). 30 (1982) 758-761.

[79] B. Borcsa, D. Csupor, P. Forgo, U. Widowitz, R. Bauer, J. Hohmann, Nat. Prod. Commun. 6 (2011) 527-536.

[80] Q. Xu, Y. Wang, C. Liu, Z. Liu, S. Liu, Anal. Sci. 19 (2003) 1599-1603.

[81] Y. Liang, J.-L. Wu, E.L.-H. Leung, H. Zhou, Z. Liu, G. Yan, Y. Liu, L. Liu, N. Li, Molecules 21 (2016) 437.

[82] D. Csupor, E.M. Wenzig, I. Zupkó, K. Wölkart, J. Hohmann, R. Bauer, J. Chromatogr. A 1216 (2009) 2079-2086.

[83] B. Borcsa, U. Widowitz, D. Csupor, P. Forgo, R. Bauer, J. Hohmann, Fitoterapia 82 (2011) 365-368.

[84] T. Kiss, B. Borcsa, P. Orvos, L. Tálosi, J. Hohmann, D. Csupor, Planta Med. (2017) doi: 10.1055/s-0043-109556.

[85] B.L. Borcsa, Investigations of Diterpene Alkaloids Isolated from Aconitum Anthora L. and A. Moldavicum L., and of Aconitine-Derived Lipo-Alkaloids, Szegedi Tudományegyetem, 2014. (PhD Thesis)

[86] J. Friese, J. Gleitz, U.T. Gutser, J.F. Heubach, T. Matthiesen, B. Wilffert, N. Selve, Eur. J. Pharmacol. 337 (1997) 165-74.

[87] T.Y.K. Chan, S.P. Kelly, Med. J. Aust. 153 (1990) 499.

[88] A. Ameri, Prog. Neurobiol. 56 (1998) 211-235.

[89] Q. Liu, L. Zhuo, L. Liu, S. Zhu, A. Sunnassee, M. Liang, L. Zhou, Y. Liu, Forensic Sci. Int. 212 (2011) e5-e9.

[90] F.N. Dzhakhangirov, M.N. Sultankhodzhaev, B. Tashkhodzhaev, B.T. Salimov, Chem. Nat. Compd. 33 (1997) 190202. 
[91] Y.P. Wang, W.Z. Chen, X.L. Wang, Z. Hua, Yao Xue Xue Bao 31 (1996) 581-4. (In Chinese)

[92] S.N. Wright, Mol. Pharmacol. 59 (2001) 183-92.

[93] Y. V. Vakhitova, E.I. Farafontova, R.Y. Khisamutdinova, V.M. Yunusov, I.P. Tsypysheva, M.S. Yunusov, Russ. J. Bioorganic Chem. 39 (2013) 92-101.

[94] M.-K. Song, H. Liu, H.-L. Jiang, J.-M. Yue, G.-Y. Hu, Eur. J. Pharmacol. 531 (2006) 47-53.

[95] W.Z. Chen, Y.L. Dong, Y.F. Zhang, G.S. Ding, Zhongguo Yao Li Xue Bao 4 (1983) 247-50. (In Chinese)

[96] Y.P. Wang, W.Z. Chen, W.K. Sun, J.X. Wu, Zhongguo Yao Li Xue Bao 13 (1992) 231-4.

[97] C.-J. Tai, M. El-Shazly, T.-Y. Wu, K.-T. Lee, D. Csupor, J. Hohmann, F.-R. Chang, Y.-C. Wu, T.-Y. Wu, K.-T. Lee, Planta Med. 81 (2015) 1017-1028.

[98] X. Huang, Y. Yang, J. Zhu, Y. Dai, J. Pu, Basic Clin. Pharmacol. Toxicol. 104 (2009) 145-154.

[99] M.C. Sanguinetti, M. Tristani-Firouzi, Nature 440 (2006) 463-469.

[100] D. Dobrev, A. Friedrich, N. Voigt, N. Jost, E. Wettwer, T. Christ, M. Knaut, U. Ravens, Circulation 112 (2005) 3697706.

[101] N. Hashimoto, T. Yamashita, N. Tsuruzoe, Pharmacol. Res. 54 (2006) 136-141.

[102] Y. Li, D. Tu, H. Xiao, Y. Du, A. Zou, Y. Liao, S. Dong, J. Ethnopharmacol. 131 (2010) 187-195.

[103] S. Xie, Y. Jia, A. Liu, R. Dai, L. Huang, J. Ethnopharmacol. 166 (2015) 375-379.

[104] X. Huang, Y. Yang, J. Zhu, D. Xu, J. Peng, J. Liu, J. Cardiovasc. Pharmacol. 59 (2012) 77-83.

[105] P. Forgo, B. Borcsa, D. Csupor, L. Fodor, R. Berkecz, A. Molnár V, J. Hohmann, Planta Med. 77 (2011) 368-373.

[106] T. Kiss, P. Orvos, S. Bánsághi, P. Forgo, N. Jedlinszki, L. Tálosi, J. Hohmann, D. Csupor, Fitoterapia 90 (2013) 8593.

[107] M. Kaneta, H. Hikichi, S. Endo, N. Sugiyama, Agric. Biol. Chem. 43 (1979) 657-658.

[108] Y. Takeda, K. Fukumoto, M. Tachibana, T. Shingu, T. Fujita, T. Ichihara, Phytochemistry 29 (1990) 1591-1593.

[109] F. Ren, F. Wang, L. Wang, G. Wei, X. Li, X. Jiang, Process for Extraction of Spiratisanin A from Spiraea Japonica and Application for Treating Tumor., 2016. (Patent: CN 105541631 A 20160504, In Chinese)

[110] X.-D. Qin, S. Yang, Y. Zhao, L.-X. Wang, F.-C. Ren, F. Wang, Helv. Chim. Acta 99 (2016) 237-240.

[111] G.Y. Zuo, H.P. He, B.G. Wang, X. Hong, Y.M. Hu, X.J. Hao, Chinese Chem. Lett. 14 (2003) 383-384.

[112] G. Zuo, H. He, Y. Shen, X. Xu, Z. Wang, C. Yan, X. Hao, Planta Med. 75 (2009) 1349-1351.

[113] X. Hong, J.L. Nie, X.J. Hao, Chinese Chem. Lett. 7 (1996) 133-134.

[114] J.-L.J. Nie, X.X.-J.X. Hao, Acta Bot. Yunnanica 18 (1996) 226-228.

[115] H.-Y.Y. Liu, S. Gao, Y.-T.T. Di, C.-X.X. Chen, Y. L??, L. Zhang, Q.-T.T. Zheng, X.-J.J. Hao, Y. Lu, L. Zhang, Q.-T.T. Zheng, X.-J.J. Hao, Y. L??, L. Zhang, Q.-T.T. Zheng, X.-J.J. Hao, Y. Lu, L. Zhang, Q.-T.T. Zheng, X.-J.J. Hao, Helv. Chim. Acta 90 (2007) 1386-1390.

[116] G. Zuo, H. He, X. Hong, Y. Shen, X. Hao, Acta Bot. Yunnanica 27 (2005) 101-106.

[117] H. Oh, H. Shin, G.-S. Oh, H.-O. Pae, K.-Y. Chai, H.-T. Chung, H.-S. Lee, Phytochem. 64 (2003) 1113-1118.

[118] W.-Y. Lee, B.H. Kim, Y.H. Lee, H.G. Choi, B.H. Jeon, S. Il Jang, Y.-J.S. Kim, H.T. Chung, Y.-J.S. Kim, K.-Y. Chai, Bull. Korean Chem. Soc. 25 (2004) 1555-1558.

[119] Z. Cui, W. Liu, Y. Zhang, C. Wu, F. Dong, W. Wang, Zhongguo Shiyan Fangjixue Zazhi 17 (2011) 61-64. (In Chinese)

[120] H. Xie, X. Wei, B. Wei, Zhongcaoyao 25 (1994) 569-570,574. (In Chinese)

[121] Z. Dong, W. Wang, W. Xu, Zhongguo Shiyan Fangjixue Zazhi 20 (2014) 93-97. (In Chinese)

[122] L. Horhammer, R. Hansel, W. Endres, Arch. Pharm. Ber. Dtsch. Pharm. Ges. 289 (1956) 133-140.

[123] L. Murgu, R.R. Paris, Plantes Med. Phyther. 4 (1970) 201-214.

[124] T. Bodalski, W. Cisowski, Diss. Pharm. Pharmacol. 21 (1969) 443-447.

[125] U.R. Mughal, R. Mehmood, A. Malik, B. Ali, R.B. Tareen, Helv. Chim. Acta 95 (2012) 100-105.

[126] T.K. Chumbalov, L.T. Pashinina, N.D. Storozhenko, Chem. Nat. Compd. 12 (1976) 232-233.

[127] T.K. Chumbalov, L.T. Pashinina, Z.A. Leiman, N.D. Storozhenko, R.Z. Shukenova, in:, Ref. Dokl. Soobshch. Mendeleevsk. S'ezd Obs. Prikl. Khim., 11th, “Nauka," 1975, p. 124. (In Russian)

[128] T.K. Chumbalov, L.T. Pashinina, N.D. Storozhenko, Khimiya Prir. Soedin. 11 (1975) 425-426. (In Russian)

[129] B.T. Ahn, K.J. Oh, S.K. Park, S.G. Chung, E.H. Cho, J.G. Kim, J.S. Ro, K.S. Lee, Saengyak Hakhoechi 27 (1996) 178183. (In Korean)

[130] L.-C. Lin, C.-J. Chou, L.-M. Yang, Chinese Pharm. J. 51 (1999) 299-305.

[131] G.A. Sennikov, N.F. Komissarenko, Farmatsevtichnii Zhurnal (Kiev) 29 (1974) 84-87. (In Ukrainian)

[132] S.W. Jang, W.S. Suh, C.S. Kim, K.H. Kim, K.R. Lee, Arch. Pharm. Res. 38 (2015) 1943-1951.

[133] M. Hye Yean, J. Sun Kim, S. Sik Kang, Y. Shik Kim, Helv. Chim. Acta 97 (2014) 1123-1131.

[134] W. Wang, F. Dong, X. Liu, L. Han, H. Shi, Y. Liu, Anti Rheumatoid Arthritis Effective Part of the Stem and Branch of the Spiraea Salicifolia and Preparation Method and Application Thereof., 2016. (Patent: CN 105796680 A 20160727, In Chinese)

[135] W. Wang, F. Dong, X. Liu, L. Han, H. Shi, Y. Liu, A Spiraea Salicifolia Root Rheumatoid Arthritis-resisting Effective Constituents and Their Making Method and Application, 2016. (Patent: CN 105560445 A 20160511 , In Chinese).

[136] M.I. Choudhary, N. Naheed, A. Abbaskhan, S. Ali, Atta-ur-Rahman., Phytochem. 70 (2009) 1467-1473.

[137] T.-S. Wu, C.-C. Hwang, P.-C. Kuo, T.-H. Kuo, A.G.A.G. Damu, C.-R. Su, Chem. Pharm. Bull. (Tokyo). 52 (2004) 12271230.

[138] S.-Y. Kim, N.-Y. Song, J.-G. Cho, J.-H. Kwon, M.-C. Song, E.M. Ahn, H.C. Kang, N.-I. Baek, Chem. Nat. Compd. 51 (2015) 873-876. 
[139] Y. Tanabe, A. Kita, Yakugaku Zasshi 100 (1980) 355-358. (In Japanese)

[140] T. Hou, Y. Teng, Q. Sun, Z. Yu, Fitoterapia 80 (2009) 237-240.

[141] T.-S. Wu, C.-C. Hwang, P.-C. Kuo, A. G. Damu, C.-J. Chou, C.-F. Chen, Heterocycles 57 (2002) 1495.

[142] G.A. Sennikov, L.I. Dranik, Farmatsevtichnii Zhurnal (Kiev) 27 (1972) 68-70.

[143] G.A. Sennikov, L.I. Dranik, G. V Makarova, Farmatsevtichnii Zhurnal (Kiev) 25 (1970) 45-48. (In Ukrainian)

[144] H. Oh, G.-S. Oh, W.-G. Seo, H.-O. Pae, K.-Y. Chai, T.-O. Kwon, Y.-H. Lee, H.-T. Chung, H.-S. Lee, J. Nat. Prod. 64 (2001) 942-944.

[145] H.S. Youn, B.S. Chung, Saengyak Hakhoechi 18 (1987) 107-111. (In Korean)

[146] G.Y. Zuo, H.P. He, X. Hong, W.M. Zhu, Y.M. Hu, X.S. Yang, X.J. Hao, Chinese Chem. Lett. 12 (2001) 147-150.

[147] G.Y. Zuo, H.P. He, X. Hong, W.M. Zhu, X.S. Yang, X.J. Hao, Heterocycles 55 (2001) 487-493.

[148] M. Li, X.B. Du, Y.M. Shen, B.G. Wang, X.J. Hao, Chinese Chem. Lett. 10 (1999) 827-830.

[149] L.-M. Fan, H.-P. He, Y.-M. Shen, X.-J. Hao, J. Integr. Plant Biol. 47 (2005) 120-123.

[150] V.D. Gorbunov, V.I. Sheichenko, A.I. Ban'kovskii, Khimiya Prir. Soedin. (1976) 124-125. (In Russian)

[151] G. Goto, K. Sasaki, N. Sakabe, Y. Hirata, Tetrahedron Lett. 11 (1968) 1369-1373.

[152] F.-P. Wang, X.-T. Liang, Alkaloids. Chem. Biol. 59 (2002) 1-280.

[153] X. Yang, X. Hao, Acta Bot. Yunnanica 15 (1993) 421-423. (In Chinese)

[154] B.-G. Wang, L. Li, X.-S. Yang, Z.-H. Chen, X.-J. Hao, Heterocycles 53 (2000) 1343-1350.

[155] Y.M. Shen, H.P. He, Y.S. Zhang, B.G. Wang, X.J. Hao, Chinese Chem. Lett. 11 (2000) 789-792.

[156] H.-Y. Liu, W. Ni, C.-X. Chen, Y.-T. Di, X.-J. Hao, Helv. Chim. Acta 92 (2009) 1198-1202.

[157] X. Hao, M. Node, T. Taga, Y. Miwa, J. Zhou, S. Chen, K. Fuji, Chem. Pharm. Bull. (Tokyo). 35 (1987) 1670-1672.

[158] M. Node, X. Hao, J. Zhou, S. Chen, T. Taga, Y. Miwa, K. Fuji, Heterocycles 30 (1990) 635-643.

[159] X. Hao, J. Zhou, S. Chen, K. Fuji, M. Node, Acta Bot. Yunnanica 13 (1991) 452-454. (In Chinese)

[160] X. Hao, M. Node, J. Zhou, S. Chen, K. Fuji, Acta Bot. Yunnanica 16 (1994) 301-304. (In Chinese)

[161] X. Hao, J. Zhou, K. Fuji, M. Node, Acta Bot. Yunnanica 14 (1992) 314-318. (In Chinese)

[162] L. Li, Y.-M. Shen, X.-S. Yang, W.-L. Wu, B. Wang, Z.-H. Chen, X.-J. Hao, Brain Res. 944 (2002) 205-209.

[163] B. Wang, B. Liu, G. Zuo, X. Hao, W. Bingui, L. Bin, Z. Guoying, H. Xiaojiang, Yunnan Zhiwu Yanjiu 22 (2000) 209213.

[164] L. Fan, Z. Zhang, Y. Shen, X. Hao, Biochem. Syst. Ecol. 32 (2004) 75-78.

[165] K.D. Jin, J. Korean Chem. Soc. 11 (1967) 111-116. (In Korean)

[166] X. Hao, Y. Shen, L. Li, H. He, Curr. Med. Chem. 10 (2003) 2253-2263.

[167] J.W. Herrick, Compound Decoction of Mashed and Powdered Dried Roots Taken for Side Pain, State University of New York, 1977. (PhD Thesis)

[168] N. Turner, R. Bouchard, D. Kennedy, Ethnobotany of the Okanagan-Colville Indians of British Columbia and Washington. British Columbia Provincial Museum, BC Provincial Museum, Victoria, British Columbia, 1980.

[169] H.-P. He, Y.-M. Shen, J.-X. Zhang, G.-Y. Zuo, X.-J. Hao, J. Nat. Prod. 64 (2001) 379-380.

[170] E.P. Abraham, N.G. Heatley, R. Bolt, E.M. Osborn, Nature 157 (1946) 511-511.

[171] J. Lee, J. Lee, J. Lim, S. Sim, D. Park, J. Med. Plants Res. 2 (2008) 59-65.

[172] Y. Teng, Q. Yang, Z. Yu, G. Zhou, Q. Sun, H. Jin, T. Hou, World J. Microbiol. Biotechnol. 26 (2010) 9-14.

[173] X. Liu, M. Li, Y. Mo, W. Quan, Mod. Food Sci. Technol. 30 (2014) 25-29.

[174] T. Hou, L. Zhou, Spiraea Extract as Fungicide and Its Preparation., 2007. (Patent CN 1943361 A 20070411, In Chinese)

[175] Y. Teng, Z. Yu, W. Cui, X. Zhang, X. Quan, Q. Sun, T. Hou, Zhongguo Nongye Kexue (Beijing, China) 42 (2009) 23802385. (In Chinese)

[176] Q. Kong, Application of Spiraea Alpina Extract in Manufacturing Antiviral Drugs., 2014. (Patent CN 103610705 A 20140305, In Chinese)

[177] Y. Ma, X.-Y. Mao, L.-J. Huang, Y.-M. Fan, W. Gu, C. Yan, T. Huang, J.-X. Zhang, C.-M. Yuan, X.-J. Hao, Fitoterapia 109 (2016) 8-13.

[178] Z. Shen, L. Zhang, P. Chen, L. Duan, Nat. Prod. Res. Dev. 16 (2004) 138-142.

[179] L. Li, M. Li, Y. Shen, Z. Chen, X. Du, X. Hao, Nat. Prod. Res. Dev. 14 (2002) 7-10.

[180] C. Yan, L. Huang, H.-C.H. Liu, D.-Z. Chen, H.-C.H. Liu, X.-H. Li, Y. Zhang, M.-Y. Geng, Q. Chen, X.-J. Hao, Bioorg. Med. Chem. Lett. 24 (2014) 1884-1888.

[181] W. Wang, H. Liu, S. Wang, X. Hao, L. Li, Cell Res. 21 (2011) 730-740.

[182] A.Y. Parkhomenko, E.T. Oganesyan, O.A. Andreeva, E.G. Dorkina, E.O. Paukova, Z.S. Agadzhanyan, Pharm. Chem. J. 40 (2006) 627-632.

[183] L. Mihajlovic, J. Radosavljevic, L. Burazer, K. Smiljanic, T. Cirkovic Velickovic, Phytochemistry 109 (2015) 125-132.

[184] N. Wopfner, B. Jahn-Schmid, G. Schmidt, T. Christ, G. Hubinger, P. Briza, C. Radauer, B. Bohle, L. Vogel, C. Ebner, R. Asero, F. Ferreira, R. Schwarzenbacher, Mol. Immunol. 46 (2009) 2090-2097.

[185] N. Wopfner, G. Gadermaier, M. Egger, R. Asero, C. Ebner, B. Jahn-Schmid, F. Ferreira, Int. Arch. Allergy Immunol. 138 (2005) 337-346.

[186] J. Bouley, R. Groeme, M. Le Mignon, K. Jain, H. Chabre, V. Bordas-Le Floch, M.-N. Couret, L. Bussieres, A. Lautrette, M. Naveau, V. Baron-Bodo, V. Lombardi, L. Mascarell, T. Batard, E. Nony, P. Moingeon, J. Allergy Clin. Immunol. 136 (2015) 1055-1064.

[187] T.H. Porter, T.J. Mabry, Phytochemistry 8 (1969) 793-794. 
[188] S. Milosavljevic, V. Bulatovic, M. Stefanovic, J. Serbian Chem. Soc. 64 (1999) 397-442.

[189] W. Raszeja, S. Gill, Planta Med. 32 (1977) 319-322.

[190] A.Y. Parkhomenko, O.A. Andreeva, E.T. Oganesyan, M.N. Ivashev, Pharm. Chem. J. 39 (2005) 149-153.

[191] M. Stefanović, I. Aljančić-Solaja, S. Milosavljević, M. Stefanovic, I. Aljancic-Solaja, S. Milosavljevic, Phytochemistry 26 (1987) 850-852.

[192] O. Taglialatela-Scafati, F. Pollastro, A. Minassi, G. Chianese, L. De Petrocellis, V. Di Marzo, G. Appendino, European J. Org. Chem. 2012 (2012) 5162-5170.

[193] E. Błoszyk, U.U. Rychlewska, B. Szczepanska, M. Buděšínský, B. Drożdż, M. Holub, Collect. Czechoslov. Chem. Commun. 57 (1992) 1092-1102.

[194] W. Herz, G. Hörgenauer, J. Org. Chem. 26 (1961) 5011-5013.

[195] S. Solujic, S. Sukdolak, N. Vukovic, N. Niciforovic, S. Stanic, J. Serbian Chem. Soc. 73 (2008) 1039-1049.

[196] J.P. David, A.J. de O. Santos, M.L. da S. Guedes, J.M. David, H.-B. Chai, J.M. Pezzuto, C.K. Angerhofer, G.A. Cordell, Pharm. Biol. 37 (1999) 165-168.

[197] E. Bianchi, C. Culvenor, J. Loder, Aust. J. Chem. 21 (1968) 1109.

[198] C.M. Sturgeon, K. Craig, C. Brown, N.T. Rundle, R.J. Andersen, M. Roberge, Planta Med. 71 (2005) 938-943.

[199] J.K. Rugutt, K.J. Rugutt, J. Agric. Food Chem. 45 (1997) 4845-4849.

[200] S. Foster, J.A. Duke, A Field Guide to Medicinal Plants and Herbs of Eastern and Central North America, 2nd ed., Houghton Mifflin Company, Boston, New York, 2000.

[201] P.B. Hamel, M.U. Chiltoskey, Cherokee Plants and Their Uses: A 400 Year History, Herald Publishing Company, 1975.

[202] M.R. Gilmore, Collect. Nebraska State Hist. Soc. 17 (1913) 358-370.

[203] G. Tantaquidgeon, Folk Medicine of the Delaware and Related Algonkian Indians, Pennsylvania Historical Commission Anthropological Papers, Harrisburg, 1972.

[204] G. Tantaquidgeon, A Study of Delaware Indian Medicine Practice and Folk Beliefs, Pennsylvania Historical Commission, Harrisburg, 1942.

[205] F.G. Speck, Primit. Man 14 (1941) 49.

[206] J.W. Herrick, Iroquois Medical Notany, State University of New York, Albany, 1977.

[207] J.B. Romero, in:, Bot. Lore Californian Indians, 1954, p. 13.

[208] V.M. Dirsch, H. Stuppner, A.M. Vollmar, Planta Med. 67 (2001) 557-559.

[209] S.J. Torrance, R.M. Wiedhopf, J.R. Cole, J. Pharm. Sci. 64 (1975) 887-888.

[210] R. Villagomez, J.A. Collado, E. Muñoz, G. Almanza, O. Sterner, J. Biomed. Sci. Eng. 7 (2014) 833-847.

[211] S. AbouZid, Y. Orihara, M. Kawanaka, Nat. Prod. Commun. 2 (2007) 177-180.

[212] M. Abdel-Aziz, S.M. El-Sheikh, G. Shams, N.N. El-Maraghy, A.F. El-Mahdy, S.A. El-Marakby, Alex. J. Pharm. Sci. 5 (1991) 98-103.

[213] E. Rodríguez, M.O. Dillon, T.J. Mabry, J.C. Mitchell, G.H. Towers, Experientia 32 (1976) 236-8.

[214] R. Cotugno, R. Fortunato, A. Santoro, D. Gallotta, A. Braca, N. De Tommasi, M.A. Belisario, Cell Prolif. 45 (2012) 53-65.

[215] R. Villagomez, G.C. Rodrigo, I.G. Collado, M.A. Calzado, E. Muñoz, B. Åkesson, O. Sterner, G.R. Almanza, R.-D. Duan, Anticancer Res. 33 (2013) 3799-3805.

[216] J.T. Arnason, B.J.R. Philogène, F. Duval, D. McLachlan, A.K. Picman, G.H.N. Towers, F. Balza, J. Nat. Prod. 48 (1985) 581-584.

[217] A.K. Picman, J. Picman, G.H.N. Towers, Contact Dermatitis 8 (1982) 294-301.

[218] R. Martino, M.F. Beer, O. Elso, O. Donadel, V. Sülsen, C. Anesini, Toxicol. Vitr. 29 (2015) 1529-1536.

[219] V.P. Sülsen, S.I. Cazorla, F.M. Frank, L.C. Laurella, L. V Muschietti, C.A. Catalán, V.S. Martino, E.L. Malchiodi, PLoS Negl. Trop. Dis. 7 (2013) e2494.

[220] A.L. Lastra, T.O. Ramírez, L. Salazar, M. Martínez, J. Trujillo-Ferrara, J. Ethnopharmacol. 95 (2004) 221-227.

[221] J. Aponte, H. Yang, A. Vaisberg, D. Castillo, E. Málaga, M. Verástegui, L. Casson, N. Stivers, P. Bates, R. Rojas, I. Fernandez, W. Lewis, C. Sarasara, M. Sauvain, R. Gilman, G. Hammond, Planta Med. 76 (2010) 705-707.

[222] S.A.M. Abdelgaleil, M.E.I. Badawy, T. Suganuma, K. Kitahara, S. A. M. Abdelgaleil, African J. Microbiol. Res. 5 (2011) 3385-3393.

[223] C. Ramesh, K. Harakishore, U.S.N. Murty, B. Das, ARKIVOC 2003 (2004) 126.

[224] Q. He, X.C. Liu, R.Q. Sun, Z.W. Deng, S.S. Du, Z.L. Liu, J. Chem. 2014 (2014) 1-6.

[225] B. Csupor-Löffler, Z. Hajdú, I. Zupkó, B. Réthy, G. Falkay, P. Forgo, J. Hohmann, Phyther. Res. 23 (2009) 672-676.

[226] J.G. Blanco, R.R. Gil, C.I. Alvarez, L.C. Patrito, S. Genti-Raimondi, A. Flury, FEBS Lett. 409 (1997) 396-400.

[227] V.P. Sulsen, S.I. Cazorla, F.M. Frank, C. Anesini, L. V Muschietti, V.S. Martino, Lat. Am. J. Pharm. 30 (2011) 202208.

[228] V.P. Sülsen, F.M. Frank, S.I. Cazorla, C.A. Anesini, E.L. Malchiodi, B. Freixa, R. Vila, L. V Muschietti, V.S. Martino, Antimicrob. Agents Chemother. 52 (2008) 2415-2419.

[229] V. Sülsen, D. Gutierrez Yappu, L. Laurella, C. Anesini, A. Gimenez Turba, V. Martino, L. Muschietti, Evidence-Based Complement. Altern. Med. 2011 (2011) 1-4.

[230] V.P. Sülsen, V. Puente, D. Papademetrio, A. Batlle, V.S. Martino, F.M. Frank, M.E. Lombardo, PLoS One 11 (2016) e0150526.

[231] V. Sülsen, P. Barrera, L. Muschietti, V. Martino, M. Sosa, Molecules 15 (2010) 545-553. 
[232] C.F. da Silva, D. d. G.J. Batista, J.S. De Araujo, M.M. Batista, J. Lionel, E.M. de Souza, E.R. Hammer, P.B. da Silva, M. De Mieri, M. Adams, S. Zimmermann, M. Hamburger, R. Brun, W. Schuhly, M. d. N.C. Soeiro, Antimicrob. Agents Chemother. 57 (2013) 5307-5314.

[233] V.P. Sülsen, F.M. Frank, S.I. Cazorla, P. Barrera, B. Freixa, R. Vila, M.A. Sosa, E.L. Malchiodi, L. V Muschietti, V.S. Martino, Int. J. Antimicrob. Agents 37 (2011) 536-543.

[234] H. Cai, X. Meng, Y. Li, C. Yang, Y. Liu, Phyther. Res. 28 (2014) 1679-1686.

[235] N.J. Lawrence, A.T. McGown, J. Nduka, J.A. Hadfield, R.G. Pritchard, Bioorg. Med. Chem. Lett. 11 (2001) 429-431.

[236] C. Schomburg, W. Schuehly, F.B. Da Costa, K.-H. Klempnauer, T.J. Schmidt, Eur. J. Med. Chem. 63 (2013) 313320.

[237] M. Li, X. Liu, S. Guo, M. Dong, T. Song, Q. Shi, Hebei Yike Daxue Xuebao 34 (2013) 869-872. (In Chinese)

[238] M. Li, X. Liu, S. Guo, M. Dong, Z. Du, P. Gao, T. Song, Q. Shi, Nat. Prod. Res. Dev. 25 (2013) 529,555-557.

[239] Z. Li, B. Qin, X. Qi, J. Mao, D. Wu, Arch. Pharm. Res. 39 (2016) 1441-1453.

[240] Y. Li, T. Li, S. Wen, Y. Zhang, Z. Tian, Q. Shi, N. Suzuki, Zhongguo Yaolixue Tongbao 26 (2010) 112-115. (In Chinese)

[241] Y. Li, B. Cong, M. Dong, M. Zhang, S. Wang, Q. Shi, Zhongcaoyao 41 (2010) 1336-1338. (In Chinese)

[242] J. Chen, L. Zhao, M. Dong, S. Wang, Q. Qin, H. Chen, Q. Shi, Aibian, Jibian, Tubian 22 (2010) 440-443. (In Chinese)

[243] Y. Li, Z.-Y. Ni, M.-C. Zhu, M. Dong, S.-M. Wang, Q.-W. Shi, M.-L. Zhang, Y.-F. Wang, C. Huo, H. Kiyota, B. Cong, Zeitschrift Für Naturforsch. C 67 (2012) 375-380.

[244] T. Konishi, Y. Shimada, T. Nagao, H. Okabe, T. Konoshima, Biol. Pharm. Bull. 25 (2002) 1370-1372.

[245] L. Venables, T.C. Koekemoer, M. Van de Venter, E.D. Goosen, South African J. Bot. 103 (2016) 216-221.

[246] Z. Weng, H. Gao, J. Hu, Y. Fan, H. Wang, L. Li, Oncol. Rep. 35 (2015) 833-840.

[247] W. Di, M. Khan, A. Rasul, M. Sun, Y. Sui, L. Zhong, L. Yang, Q. Zhu, L. Feng, T. Ma, Oncol. Rep. 32 (2014) 15851593.

[248] J.Y. Seo, J. Park, H.J. Kim, I.A. Lee, J.-S. Lim, S.S. Lim, S.-J. Choi, J.H.Y. Park, H.J. Kang, J.-S. Kim, J. Med. Food 12 (2009) 1038-1045.

[249] J.Y. Seo, S.S. Lim, J.R. Kim, J.-S. Lim, Y.R. Ha, I.A. Lee, E.J. Kim, J.H.Y. Park, J.-S. Kim, Phyther. Res. 22 (2008) 15001505.

[250] M. Khan, C. Ding, A. Rasul, F. Yi, T. Li, H. Gao, R. Gao, L. Zhong, K. Zhang, X. Fang, T. Ma, Int. J. Biol. Sci. 8 (2012) 533-547.

[251] A. Rasul, M. Khan, B. Yu, M. Ali, Y.J. Bo, H. Yang, T. Ma, Arch. Pharm. Res. 36 (2013) 1262-1269.

[252] A. Kumar, D. Kumar, A.K. Maurya, Y.S. Padwad, V.K. Agnihotri, Phytochem. Lett. 18 (2016) 117-121.

[253] M. Wu, H. Zhang, J. Hu, Z. Weng, C. Li, H. Li, Y. Zhao, X. Mei, F. Ren, L. Li, PLoS One 8 (2013) e76000.

[254] Z. Stojanović-Radić, L. Čomić, N. Radulović, P. Blagojević, M. Denić, A. Miltojević, J. Rajković, T. Mihajilov-Krstev, Eur. J. Clin. Microbiol. Infect. Dis. 31 (2012) 1015-1025.

[255] C. Liu, A.K. Mishra, B. He, R. Tan, Chinese Sci. Bull. 46 (2001) 498-501.

[256] C.L. Cantrell, L. Abate, F.R. Fronczek, S.G. Franzblau, L. Quijano, N.H. Fischer, Planta Med. 65 (1999) 351-355.

[257] P.S. Kalsi, V.B. Sood, A.B. Masih, D. Gupta, K.K. Talwar, Phytochemistry 22 (1983) 1387-1392.

[258] Parlagfúlekvár: https://shop.tatrasobarlang.hu/Parlagfu_lekvar (2015).

[259] B. Borcsa, L. Fodor, D. Csupor, P. Forgo, A. Molnár, J. Hohmann, Planta Med. 80 (2014) 231-236.

[260] D. Csupor, P. Forgo, K. Csedő, J. Hohmann, Helv. Chim. Acta 89 (2006) 2981-2986.

[261] D. Csupor, P. Forgo, E.M. Wenzig, R. Bauer, J. Hohmann, J. Nat. Prod. 71 (2008) 1779-1782.

[262] D. Csupor, P. Forgo, I. Zupkó, P. Szabó, J. Hohmann, Zeitschrift Für Naturforsch. B 62b (2007) 135-141.

[263] J. Hohmann, P. Forgo, Z. Hajdú, E. Varga, I. Máthé, J. Nat. Prod. 65 (2002) 1069-1072.

[264] R.G. Kelsey, M.S. Morris, N.R. Bhadane, F. Shafizadeh, Phytochemistry 12 (1973) 1345-1350.

[265] N. Hashimoto, T. Yamashita, N. Tsuruzoe, J. Cardiovasc. Pharmacol. 51 (2008) 162-169.

[266] L. Polonchuk, Front. Pharmacol. 3 (2012).

[267] Z. Oláh, A.I. Bush, D. Aleksza, B. Gálik, E. Ivitz, L. Mácsai, Z. Janka, Z. Karman, J. Kálmán, Z. Datki, Ecotoxicol. Environ. Saf. 144 (2017) 115-122.

[268] T. Kiss, L. Mácsai, D. Csupor, Z.L. Datki, Acta Biol. Hung. (2017) accepted.

[269] B. Poeggeler, G. Durand, A. Polidori, M.A. Pappolla, I. Vega-Naredo, A. Coto-Montes, J. Boker, R. Hardeland, B. Pucci, J. Neurochem. 95 (2005) 962-973.

[270] OECD, OECD Guidelines for the Testing of Chemicals No 407: Repeated Dose 28-Day Oral Toxicity Study in Rodents (Adopted 3 October 2008), 2008.

[271] T. Kiss, A. Szabó, G. Oszlánczi, A. Lukács, Z. Tímár, L. Tiszlavicz, D. Csupor, PLoS One 12 (2017) e0176818.

[272] K.S. Khetwal, H.K. Desai, B.S. Joshi, S.W. Pelletier, Heterocycles 38 (1994) 833-842.

[273] S.H. Shim, J.S. Kim, S.S. Kang, K.H. Son, K. Bae, Arch. Pharm. Res. 26 (2003) 709-715.

[274] Z. Chen, A. Lao, H. Wang, S. Hong, Planta Med. 54 (1988) 318-320.

[275] A. Ulubelen, H.K. Desai, S.K. Srivastava, B.P. Hart, J.C. Park, B.S. Joshi, S.W. Pelletier, A.H. Mericli, F. Mericli, R. Ilarslan, J. Nat. Prod. 59 (1996) 360-366.

[276] H. Liu, A. Katz, Planta Med. 62 (1996) 190-191.

[277] J.B. Hanuman, A. Katz, Phytochemistry 36 (1994) 1527-1535.

[278] K. Wada, T. Mori, N. Kawahara, Chem. Pharm. Bull. 48 (2000) 660-668.

[279] C. Konno, M. Shirasaka, H. Hikino, J. Nat. Prod. 45 (1982) 128-133.

[280] J. Yue, J. Xu, Y. Chen, S. Chen, Phytochemistry 37 (1994) 1467-1470. 
[281] C. von Schroff Jr., Neues Repert. Für Pharm. 20 (1871) 641-669.

[282] B. Borcsa, T. Kiss, D. Csupor, P. Orvos, L. Tálosi, J. Hohmann, Planta Med. 81 (2015).

[283] W. Ding, R. Huang, Z. Zhou, Y. Li, Molecules 20 (2015) 4450-4459.

[284] M. Stefanovic, A. Jokic, A. Behbud, Glas. Hem. Drus. Beogr. 37 (1972) 463-468. (In Serbian)

[285] V.H. Gattone, B. a Tourkow, C.M. Trambaugh, A.C. Yu, S. Whelan, C.L. Phillips, P.C. Harris, R.G. Peterson, Anat. Rec. 277A (2004) 384-395.

[286] Z.M. Vaisov, I.A. Bessonova, V.A. Tel'nov, Khimiya Prir. Soedin. (1993) 86-87. (In Russian)

[287] J. Slavík, L. Slavíková, Collect. Czechoslov. Chem. Commun. 60 (1995) 1034-1041.

[288] R.R. Paris, L. Murgu, Plantes Med. Phyther. 4 (1970) 138-149.

[289] E.A. Karpova, T.A. Polyakova, Khimiya Prir. Soedin. (2014) 145-149. (In Russian)

[290] D.H. Chen, Chinese Tradit. Herb. Med. 15 (1984) 180-184.

[291] N.G. Bisset, J. Ethnopharmacol. 4 (1981) 247-336.

[292] F.N. Dzhakhangirov, F.S. Sadritdinov, Dokl. Akad. Nauk UzSSR 30 (1973) 39-40. (In Russian)

[293] S. Gowda, P.B. Desai, V. V Hull, A. a K. Math, S.N. Vernekar, S.S. Kulkarni, Pan Afr. Med. J. 3 (2009) 17.

[294] E.G. Giannini, Can. Med. Assoc. J. 172 (2005) 367-379.

[295] A. Noori, L. Amjad, F. Yazdani, Avicenna J. Phytomedicine 4 (2014) 371-6.

[296] A.S. Ene-ojo, E.A. Chinedu, F.M. Yakasai, Int. J. Biochem. Res. Rev. 3 (2013) 119-128.

[297] M.H.R. Amorim, R.M. Gil da Costa, C. Lopes, M.M.S.M. Bastos, Crit. Rev. Toxicol. 43 (2013) 559-579.

[298] T.R. Narasimhan, N. Harindranath, S. Premlata, B.S.K. Murthy, P.V.S. Rao, Planta Med. 51 (1985) 194-197.

[299] R.B. de Oliveira, D.A.C. de Paula, B.A. Rocha, J.J. Franco, L. Gobbo-Neto, S.A. Uyemura, W.F. dos Santos, F.B. Da Costa, J. Ethnopharmacol. 133 (2011) 434-441.

[300] T.O. Elufioye, O.I. Alatise, F.A. Fakoya, J.M. Agbedahunsi, P.J. Houghton, J. Ethnopharmacol. 122 (2009) 410-415.

[301] A. Mahesh, R. Jeyachandran, L. Cindrella, D. Thangadurai, V. Veerapur, D. Muralidhara Rao, Acta Biol. Hung. 61 (2010) 175-190.

[302] Y. Li, D.-M. Zhang, J.-B. Li, S.-S. Yu, Y. Li, Y.-M. Luo, J. Nat. Prod. 69 (2006) 616-620.

[303] H.T. Chang, W.K. Rumbeiha, J.S. Patterson, B. Puschner, A.P. Knight, Vet. Pathol. 49 (2012) 398-402.

[304] Y. Piao, Y. Liu, X. Xie, J. Toxicol. Pathol. 26 (2013) 29-34.

[305] D. Csupor, Investigation of the Diterpene Alkaloids of Aconitum Species Native to the Carpathian Basin, University of Szeged, 2007. (PhD Thesis) 


\section{ACKNOWLEDGEMENTS}

I would like to express my greatest gratitude to Prof. Judit Hohmann and to Dr. Dezső Csupor for leading my PhD work with their invaluable professional knowledge.

I am thankful to Dr. Andrea Szabó, Dr. Gábor Oszlánczi and Dr. Anita Lukács for repeateddose toxicity experiment, to Dr. Zsolt László Datki and Lilla Mácsai for bdelloid rotifer assay, to Dr. László Tálosi and Dr. Péter Orvos for GIRK/hERG ion channel screening, to Prof. Károly Csedő, Dr. Botond Borcsa, Dr. Attila Ványolós, Anikó Németh, Dr. Santa Rutkovska and Dr. Irena Pučka for plant materials and identifications; Dr. Péter Forgó, Dr. Norbert Kúsz, Dr. Nikoletta Jedlinszki and Dr. Zoltán Tímár for NMR and LC-MS measurements. I am also grateful to Dr. Erika Liktor-Busa for antibacterial and to Dr. Orsolya Orbán-Gyapai for xanthine oxidase activity measurements. I owe special thanks to Dr. Orsolya Roza, Dr. Andrea Vasas and Dr. Attila Ványolós for proofreading.

My thanks are likewise due to all my colleagues in the Department of Pharmacognosy. I am especially grateful to Dr. Andrea Vasas, Dr. Dóra Rédei, Dr. Katalin Veres, Dr. Nikoletta Jedlinszki, Klára Horváth-Boros, Attila Horváth, Dr. Zoltán Zomborszki, Dr. Attila Ványolós, Dr. Barbara Tóth, Dr. Orsolya Orbán-Gyapai for help, support and friendship.

I am very grateful to my previous biology and chemistry teachers: Rozália Halápi, Erzsébet Ferencz, Alíz Jusztinné Nedelkovics, Imre László for inspiring me to learn science.

I am also grateful to Rev. László Pósa parish priest and to the entire Parish Community of Saint Anthony of Padua in Óbecse for all support and prayers.

I would like to extend my special thanks to my parents, to my brother, relatives and friends. I could not have carried out this work without their support and love.

This work was supported by the project GINOP-2.3.2-15-2016-00012 (New ways in the natural product-based drug discovery-system metabolomic approaches to discover biologically active terpenoids of herbal and microbial origin). 


\section{APPENDIX I.}

\section{A) Chemical structures of aconite alkaloids}
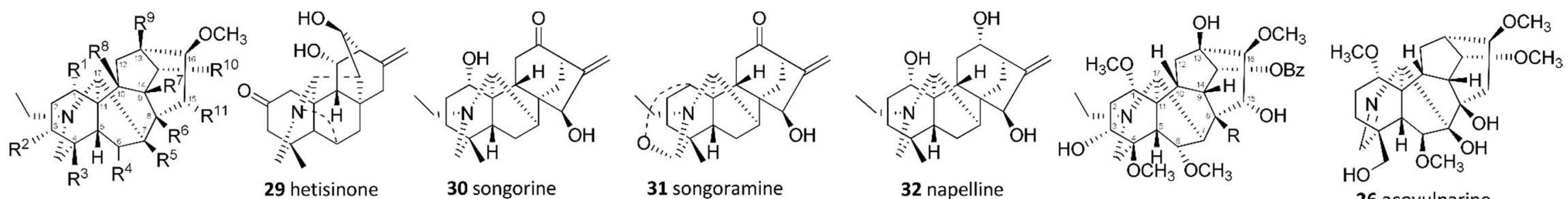

\begin{tabular}{|c|c|c|c|c|c|c|c|c|c|c|c|c|}
\hline & Compound & $\mathbf{R}^{1}$ & $\mathbf{R}^{2}$ & $\mathbf{R}^{3}$ & $\mathbf{R}^{4}$ & $\mathbf{R}^{5}$ & $\mathbf{R}^{6}$ & $\mathbf{R}^{\mathbf{7}}$ & $\mathbf{R}^{8}$ & $\mathbf{R}^{9}$ & $\mathbf{R}^{10}$ & $\mathrm{R}^{11}$ \\
\hline 1 & takaosamine & $\mathrm{OH}$ & $\mathrm{H}$ & $\mathrm{CH}_{2} \mathrm{OH}$ & $\beta-\mathrm{OCH}_{3}$ & $\mathrm{OH}$ & $\mathrm{OH}$ & $\mathrm{H}$ & $\mathrm{H}$ & $\mathrm{H}$ & $\mathrm{OH}$ & $\mathrm{H}$ \\
\hline 2 & aconosine & $\mathrm{OCH}_{3}$ & $\mathrm{H}$ & $\mathrm{H}$ & $\mathrm{H}$ & $\mathrm{H}$ & $\mathrm{OH}$ & $\mathrm{H}$ & $\mathrm{H}$ & $\mathrm{H}$ & $\mathrm{OH}$ & $\mathrm{H}$ \\
\hline 3 & dolaconine & $\mathrm{OCH}_{3}$ & $\mathrm{H}$ & $\mathrm{H}$ & H & $\mathrm{H}$ & $\mathrm{OH}$ & $\mathrm{H}$ & $\mathrm{H}$ & $\mathrm{H}$ & OAC & $\mathrm{H}$ \\
\hline 4 & delavaconitine & $\mathrm{OCH}_{3}$ & $\mathrm{H}$ & $\mathrm{H}$ & H & $\mathrm{H}$ & $\mathrm{OH}$ & $\mathrm{H}$ & $\mathrm{H}$ & $\mathrm{OH}$ & $\mathrm{OBz}$ & $\mathrm{H}$ \\
\hline 5 & acotoxicine & $\mathrm{OCH}_{3}$ & $\mathrm{OH}$ & $\mathrm{H}$ & H & $\mathrm{H}$ & $\mathrm{OH}$ & $\mathrm{H}$ & $\mathrm{H}$ & $\mathrm{H}$ & $\mathrm{OH}$ & $\mathrm{H}$ \\
\hline 6 & isotalatizidine & $\mathrm{OH}$ & $\mathrm{H}$ & $\mathrm{CH}_{2} \mathrm{OCH}_{3}$ & $\mathrm{H}$ & $\mathrm{H}$ & $\mathrm{OH}$ & $\mathrm{H}$ & $\mathrm{H}$ & $\mathrm{H}$ & $\mathrm{OH}$ & $\mathrm{H}$ \\
\hline 7 & $\begin{array}{l}\text { 10-hydroxy-8-O- } \\
\text { methyltalatizamine }\end{array}$ & $\mathrm{OCH}_{3}$ & $\mathrm{H}$ & $\mathrm{CH}_{2} \mathrm{OCH}_{3}$ & H & $\mathrm{H}$ & $\mathrm{OCH}_{3}$ & $\mathrm{H}$ & $\mathrm{OH}$ & H & $\mathrm{OH}$ & $\mathrm{H}$ \\
\hline 8 & delcosine & $\mathrm{OH}$ & $\mathrm{H}$ & $\mathrm{CH}_{2} \mathrm{OCH}_{3}$ & $\beta-\mathrm{OCH}_{3}$ & $\mathrm{OH}$ & $\mathrm{OH}$ & $\mathrm{H}$ & $\mathrm{H}$ & $\mathrm{H}$ & $\mathrm{OH}$ & $\mathrm{H}$ \\
\hline 9 & ajacine & $\mathrm{OCH}_{3}$ & $\mathrm{H}$ & $\mathrm{CH}_{2} \mathrm{Ant}$ & $\alpha-\mathrm{OCH}_{3}$ & $\mathrm{OH}$ & $\mathrm{OH}$ & $\mathrm{H}$ & $\mathrm{H}$ & H & $\mathrm{OCH}_{3}$ & $\mathrm{H}$ \\
\hline 10 & lycoctonine & $\mathrm{OCH}_{3}$ & $\mathrm{H}$ & $\mathrm{CH}_{2} \mathrm{OH}$ & $\beta-\mathrm{OCH}_{3}$ & $\mathrm{OH}$ & $\mathrm{OH}$ & $\mathrm{H}$ & $\mathrm{H}$ & H & $\mathrm{OCH}_{3}$ & $\mathrm{H}$ \\
\hline 11 & swatinine & $\mathrm{OCH}_{3}$ & $\mathrm{H}$ & $\mathrm{CH}_{2} \mathrm{OH}$ & $\mathrm{B}-\mathrm{OCH}_{3}$ & $\mathrm{OH}$ & $\mathrm{OH}$ & $\mathrm{H}$ & $\mathrm{OH}$ & H & $\mathrm{OCH}_{3}$ & $\mathrm{H}$ \\
\hline 12 & gigactonine & $\mathrm{OH}$ & H & $\mathrm{CH}_{2} \mathrm{OH}$ & $\mathrm{B}-\mathrm{OCH}_{3}$ & $\mathrm{OH}$ & $\mathrm{OH}$ & $\mathrm{OH}$ & $\mathrm{H}$ & $\mathrm{H}$ & $\mathrm{OCH}_{3}$ & $\mathrm{H}$ \\
\hline 13 & $\begin{array}{l}\text { 14-desacetyl-18- } \\
\text { demethylpubescenine }\end{array}$ & $\mathrm{OH}$ & $\mathrm{H}$ & $\mathrm{CH}_{3}$ & $\alpha-\mathrm{OH}$ & $\mathrm{OH}$ & $\mathrm{OCH}_{3}$ & $\mathrm{H}$ & $\mathrm{H}$ & $\mathrm{H}$ & $\mathrm{OH}$ & $\mathrm{H}$ \\
\hline 14 & acotoxinine & $\mathrm{OH}$ & $\mathrm{H}$ & $\mathrm{CH}_{2} \mathrm{OCH}_{3}$ & $\alpha-\mathrm{OCH}_{3}$ & $\mathrm{H}$ & OVr & $\mathrm{H}$ & $\mathrm{H}$ & $\mathrm{H}$ & $\mathrm{OH}$ & $\mathrm{H}$ \\
\hline 15 & neoline & $\mathrm{OH}$ & H & $\mathrm{CH}_{2} \mathrm{OCH}_{3}$ & $\alpha-\mathrm{OCH}_{3}$ & $\mathrm{H}$ & $\mathrm{OH}$ & $\mathrm{H}$ & H & H & $\mathrm{OH}$ & H \\
\hline 16 & neolinine & $\mathrm{OH}$ & $\mathrm{H}$ & $\mathrm{CH}_{2} \mathrm{OH}$ & $\alpha-\mathrm{OCH}_{3}$ & $\mathrm{H}$ & $\mathrm{OH}$ & $\mathrm{H}$ & $\mathrm{H}$ & $\mathrm{H}$ & $\mathrm{OH}$ & $\mathrm{H}$ \\
\hline 17 & delectinine & $\mathrm{OCH}_{3}$ & $\mathrm{H}$ & $\mathrm{CH}_{2} \mathrm{OH}$ & $\beta-\mathrm{OCH}_{3}$ & $\mathrm{OH}$ & $\mathrm{OH}$ & $\mathrm{H}$ & H & H & $\mathrm{OH}$ & $\mathrm{H}$ \\
\hline 18 & aconitine & $\mathrm{OCH}_{3}$ & $\mathrm{OH}$ & $\mathrm{CH}_{2} \mathrm{OCH}_{3}$ & $\alpha-\mathrm{OCH}_{3}$ & $\mathrm{H}$ & $O A C$ & $\mathrm{H}$ & $\mathrm{H}$ & $\mathrm{OH}$ & $\mathrm{OBz}$ & $\mathrm{OH}$ \\
\hline 19 & karakoline & $\mathrm{OH}$ & $\mathrm{H}$ & $\mathrm{CH}_{3}$ & $\mathrm{H}$ & H & $\mathrm{OH}$ & H & H & $H$ & $\mathrm{OH}$ & $H$ \\
\hline 20 & senbusine $A$ & $\mathrm{OH}$ & $\mathrm{H}$ & $\mathrm{CH}_{2} \mathrm{OCH}_{3}$ & $\alpha-\mathrm{OH}$ & $\mathrm{H}$ & $\mathrm{OH}$ & $\mathrm{H}$ & $\mathrm{H}$ & $\mathrm{H}$ & $\mathrm{OH}$ & $\mathrm{H}$ \\
\hline 21 & senbusine $C$ & $\mathrm{OH}$ & H & $\mathrm{CH}_{2} \mathrm{OCH}_{3}$ & $\alpha-\mathrm{OCH}_{3}$ & $\mathrm{H}$ & $\mathrm{OH}$ & $\mathrm{H}$ & $\mathrm{H}$ & $\mathrm{H}$ & $\mathrm{OH}$ & $\mathrm{OH}$ \\
\hline 22 & taurenine & $\mathrm{OH}$ & $\mathrm{H}$ & $\mathrm{OCH}_{3}$ & $\alpha-\mathrm{OCH}_{3}$ & $\mathrm{H}$ & $\mathrm{OCH}_{3}$ & $\mathrm{H}$ & $\mathrm{H}$ & $\mathrm{H}$ & $\mathrm{OH}$ & $\mathrm{OH}$ \\
\hline
\end{tabular}

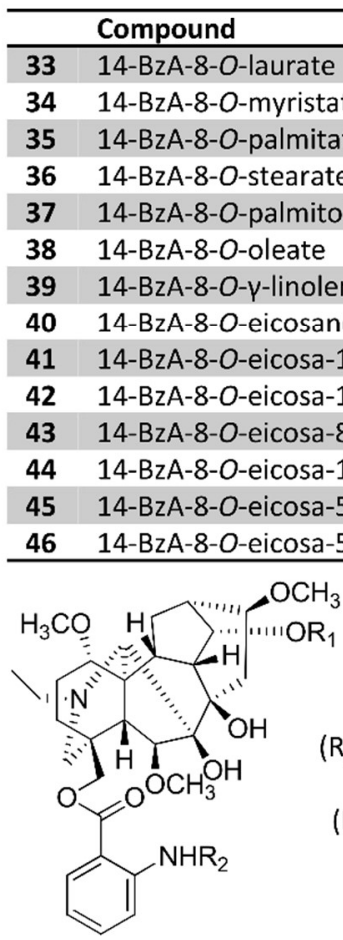

26 acovulparine

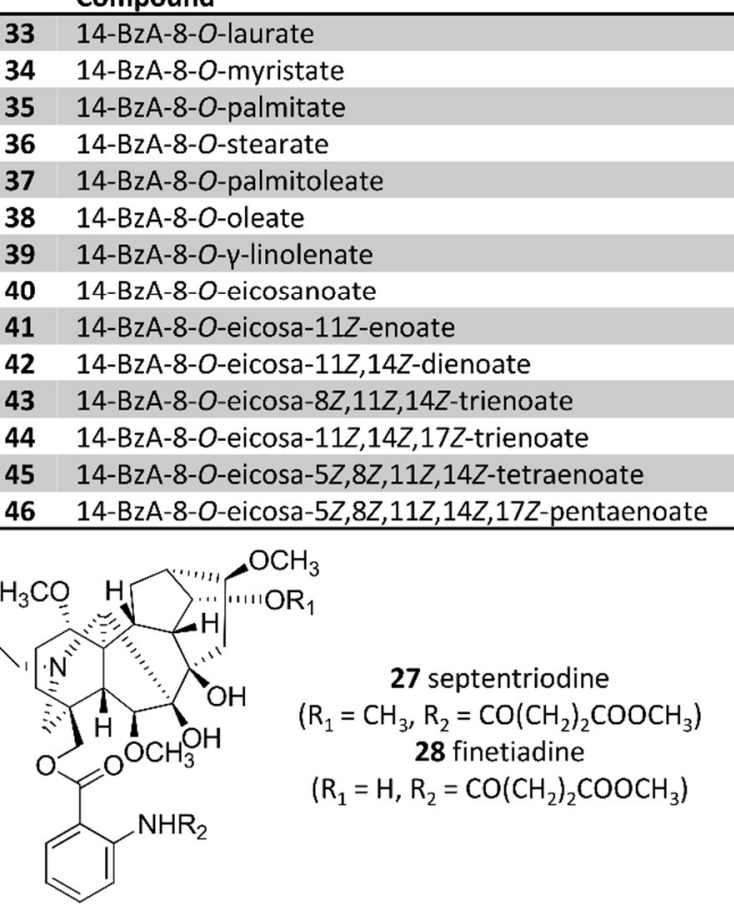




\begin{tabular}{|c|c|c|c|c|c|c|c|c|c|c|c|c|c|c|}
\hline & 23 aconitamide & $=\mathrm{CH}_{2} \mathrm{CH}_{3}$ & & $\mathrm{OCH}_{3}$ & ehydroap & & $50 \sin o$ & mont & adine & & & duclor & udine $F$ & \\
\hline & Compound name & $\mathbf{R}^{\mathbf{1}}$ & $\mathrm{R}^{2}$ & $R^{3}$ & $\mathbf{R}^{4}$ & $\mathbf{R}^{5}$ & $\mathbf{R}^{6}$ & $R^{7}$ & $\mathbf{R}^{8}$ & $\overline{R^{9}}$ & 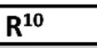 & $\mathrm{R}^{11}$ & $\mathrm{R}^{12}$ & $\mathrm{R}^{13}$ \\
\hline 48 & kirinenine $\mathrm{A}$ & $\alpha-\mathrm{OCH}_{3}$ & $\mathrm{H}$ & $\overline{O A C}$ & $\mathrm{~B}-\mathrm{OCH}_{3}$ & $\mathrm{OH}$ & $\mathrm{OH}$ & $\mathrm{H}$ & $\bar{H}$ & $\mathrm{H}$ & $\mathrm{OCH}_{3}$ & $\mathrm{H}$ & $\beta-\mathrm{OCH}_{3}$ & $\mathrm{CH}_{2} \mathrm{CH}_{3}$ \\
\hline 49 & ranaconidine & $\alpha-\mathrm{OCH}_{3}$ & $\mathrm{H}$ & $\mathrm{OH}$ & $\beta-\mathrm{OH}$ & $\mathrm{H}$ & $\mathrm{OH}$ & $\mathrm{OH}$ & $\mathrm{H}$ & $\mathrm{OH}$ & $\mathrm{OCH}_{3}$ & $\mathrm{H}$ & $\beta-\mathrm{OCH}_{3}$ & $\mathrm{CH}_{2} \mathrm{CH}_{3}$ \\
\hline 53 & weisaconitine A & $\alpha-\mathrm{OCH}_{3}$ & H & $\mathrm{H}$ & $\mathrm{H}$ & $\mathrm{H}$ & $\mathrm{OCH}_{2} \mathrm{CH}_{3}$ & H & $\mathrm{H}$ & $\mathrm{H}$ & OAC & $\mathrm{H}$ & $\beta-\mathrm{OCH}_{3}$ & $\mathrm{CH}_{2} \mathrm{CH}_{3}$ \\
\hline 54 & weisaconitine B & $\alpha-\mathrm{OCH}_{3}$ & $\mathrm{H}$ & $\mathrm{H}$ & $\mathrm{H}$ & $\mathrm{H}$ & $\mathrm{OH}$ & H & $\mathrm{OH}$ & $\mathrm{H}$ & $\mathrm{OH}$ & $\mathrm{H}$ & $\mathrm{B}-\mathrm{OCH}_{3}$ & $\mathrm{CH}_{2} \mathrm{CH}_{3}$ \\
\hline 55 & weisaconitine $C$ & $\alpha-\mathrm{OCH}_{3}$ & $\mathrm{H}$ & $\mathrm{H}$ & $\mathrm{H}$ & H & $\mathrm{OH}$ & $\mathrm{H}$ & H & $\mathrm{H}$ & $=0$ & $\mathrm{H}$ & $\mathrm{\beta}-\mathrm{OCH}_{3}$ & $\mathrm{CH}_{2} \mathrm{CH}_{3}$ \\
\hline 56 & weisaconitine D & $\alpha-\mathrm{OCH}_{3}$ & H & H & $\mathrm{H}$ & $\mathrm{H}$ & $\mathrm{OCH}_{2} \mathrm{CH}_{3}$ & H & H & $\mathrm{H}$ & $\mathrm{OH}$ & $\mathrm{H}$ & $\mathrm{B}-\mathrm{OCH}_{3}$ & $\mathrm{CH}_{2} \mathrm{CH}_{3}$ \\
\hline 57 & 14-acetoxy-8-0-methylsachaconitine & $\alpha-\mathrm{OCH}_{3}$ & $\mathrm{H}$ & $\mathrm{CH}_{3}$ & $\mathrm{H}$ & $\mathrm{H}$ & $\mathrm{OCH}_{3}$ & $\mathrm{H}$ & H & $\mathrm{H}$ & $\mathrm{OAC}$ & H & $\mathrm{B}-\mathrm{OCH}_{3}$ & $\mathrm{CH}_{2} \mathrm{CH}_{3}$ \\
\hline 58 & 14-acetoxyscaconine & $\alpha-\mathrm{OCH}_{3}$ & $\mathrm{H}$ & $\mathrm{CH}_{2} \mathrm{OH}$ & $\mathrm{H}$ & $\mathrm{H}$ & $\mathrm{OH}$ & $\mathrm{H}$ & $\mathrm{H}$ & $\mathrm{H}$ & OAC & $\mathrm{H}$ & $\beta-\mathrm{OCH}_{3}$ & $\mathrm{CH}_{2} \mathrm{CH}_{3}$ \\
\hline 59 & 14-anisoylliljestrandisine & $\alpha-\mathrm{OCH}_{3}$ & $\mathrm{H}$ & $\mathrm{CH}_{2} \mathrm{OCH}_{3}$ & $\mathrm{H}$ & $\mathrm{H}$ & $\mathrm{OH}$ & $\mathrm{H}$ & $\mathrm{H}$ & $\mathrm{H}$ & OBzM & $\mathrm{H}$ & $\mathrm{B}-\mathrm{OH}$ & $\mathrm{CH}_{2} \mathrm{CH}_{3}$ \\
\hline 60 & 14-benzoyllilijestrandisine & $\alpha-\mathrm{OCH}_{3}$ & $\mathrm{H}$ & $\mathrm{CH}_{2} \mathrm{OCH}_{3}$ & $\mathrm{H}$ & $\mathrm{H}$ & $\mathrm{OH}$ & H & $\mathrm{H}$ & $\mathrm{H}$ & $\mathrm{OBz}$ & $\mathrm{H}$ & $\beta-\mathrm{OH}$ & $\mathrm{CH}_{2} \mathrm{CH}_{3}$ \\
\hline $\begin{array}{l}65 \\
66\end{array}$ & 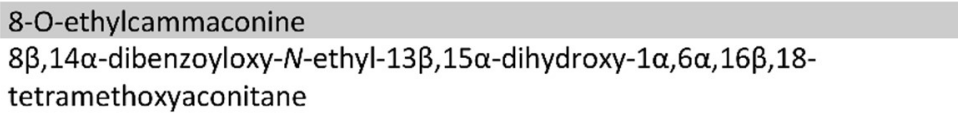 & $\alpha-\mathrm{OCH}_{3}$ & $\mathrm{H}$ & $\mathrm{CH}_{2} \mathrm{OH}$ & $\mathrm{H}$ & $\mathrm{H}$ & $\mathrm{OCH}_{2} \mathrm{CH}_{3}$ & $\mathrm{H}$ & $\mathrm{H}$ & $\mathrm{H}$ & $\mathrm{OH}$ & $\mathrm{H}$ & $\beta-\mathrm{OCH}_{3}$ & $\mathrm{CH}_{2} \mathrm{CH}_{3}$ \\
\hline 67 & carmichaenine A & $\alpha-\mathrm{OH}$ & $\mathrm{H}$ & $\mathrm{CH}_{2} \mathrm{OCH}_{3}$ & $\alpha-\mathrm{OCH}_{3}$ & H & $\mathrm{OBz}$ & $\mathrm{H}$ & $\mathrm{H}$ & $\mathrm{H}$ & $\mathrm{OH}$ & $\mathrm{H}$ & $\mathrm{B}-\mathrm{OCH}_{3}$ & $\mathrm{CH}_{2} \mathrm{CH}_{3}$ \\
\hline 68 & carmichaenine B & $\alpha-\mathrm{OH}$ & $\mathrm{H}$ & $\mathrm{CH}_{2} \mathrm{OH}$ & $\alpha-\mathrm{OCH}_{3}$ & H & $\mathrm{OH}$ & H & $\mathrm{OH}$ & $\mathrm{H}$ & $\mathrm{OH}$ & $\mathrm{H}$ & $\beta-\mathrm{OCH}_{3}$ & $\mathrm{CH}_{2} \mathrm{CH}_{3}$ \\
\hline 69 & carmichaenine C & $\alpha-\mathrm{OH}$ & H & $\mathrm{CH}_{2} \mathrm{OCH}_{3}$ & $\alpha-\mathrm{OCH}_{3}$ & H & $\mathrm{OH}$ & H & $\mathrm{H}$ & $\mathrm{H}$ & $\mathrm{OBz}$ & H & $\mathrm{B}-\mathrm{OCH}_{3}$ & $\mathrm{CH}_{2} \mathrm{CH}_{3}$ \\
\hline 70 & carmichaenine D & $\alpha-\mathrm{OH}$ & $\mathrm{H}$ & $\mathrm{CH}_{2} \mathrm{OH}$ & $\alpha-\mathrm{OCH}_{3}$ & $\mathrm{H}$ & $\mathrm{OH}$ & $\mathrm{H}$ & $\mathrm{H}$ & $\mathrm{H}$ & $\mathrm{OBz}$ & $\mathrm{H}$ & $\beta-\mathrm{OCH}_{3}$ & $\mathrm{CH}_{2} \mathrm{CH}_{3}$ \\
\hline 71 & carmichaenine $\mathrm{E}$ & $\alpha-\mathrm{OH}$ & $\mathrm{H}$ & $\mathrm{CH}_{2} \mathrm{OCH}_{3}$ & $\alpha-\mathrm{OCH}_{3}$ & $\mathrm{H}$ & $\mathrm{OH}$ & H & $\mathrm{OH}$ & $\mathrm{H}$ & $\mathrm{OH}$ & H & $\beta-\mathrm{OCH}_{3}$ & $\mathrm{CH}_{2} \mathrm{CH}_{3}$ \\
\hline 74 & ducloudine D & $\alpha-\mathrm{OH}$ & $\mathrm{OH}$ & $\mathrm{CH}_{2} \mathrm{OCH}_{3}$ & $\alpha-\mathrm{OCH}_{3}$ & H & $\mathrm{OH}$ & $\mathrm{H}$ & $\mathrm{H}$ & $\mathrm{H}$ & $\mathrm{OH}$ & $\mathrm{H}$ & $\beta-\mathrm{OCH}_{3}$ & $\mathrm{CH}_{2} \mathrm{CH}_{3}$ \\
\hline 75 & ducloudine $\mathrm{E}$ & $\alpha-\mathrm{OH}$ & $\mathrm{OH}$ & $\mathrm{CH}_{2} \mathrm{OCH}_{3}$ & $\alpha-\mathrm{OCH}_{3}$ & H & $\mathrm{OH}$ & H & $\mathrm{H}$ & $\mathrm{H}$ & $\mathrm{OAC}$ & $\mathrm{H}$ & $\mathrm{B}-\mathrm{OCH}_{3}$ & $\mathrm{CH}_{2} \mathrm{CH}_{3}$ \\
\hline 76 & nagaconitine $\mathrm{A}$ & $\alpha-\mathrm{OCH}_{3}$ & $\mathrm{OH}$ & $\mathrm{CH}_{2} \mathrm{OCH}_{3}$ & $\alpha-\mathrm{OCH}_{3}$ & $\mathrm{H}$ & $\begin{array}{l}\mathrm{OCO}\left(\mathrm{CH}_{2}\right)_{3} \\
\mathrm{OH}\end{array}$ & $\mathrm{H}$ & $\mathrm{H}$ & $\mathrm{OH}$ & $\mathrm{OBz}$ & $\alpha-\mathrm{OH}$ & $\beta-\mathrm{OCH}_{3}$ & $\mathrm{CH}_{2} \mathrm{CH}_{3}$ \\
\hline 77 & nagaconitine $B$ & $\alpha-\mathrm{OCH}_{3}$ & $\mathrm{OH}$ & $\mathrm{CH}_{2} \mathrm{OCH}_{3}$ & $\alpha-\mathrm{OCH}_{3}$ & H & $\mathrm{OH}$ & $\mathrm{H}$ & H & $\mathrm{H}$ & OMA & $=0$ & $\beta-\mathrm{OCH}_{3}$ & $\mathrm{CH}_{2} \mathrm{CH}_{3}$ \\
\hline 78 & nagaconitine $\mathrm{C}$ & $\alpha-\mathrm{OH}$ & & $\mathrm{CH}_{2} \mathrm{OCH}_{3}$ & $\alpha-\mathrm{OCH}_{3}$ & $\mathrm{H}$ & OAC & $\mathrm{H}$ & $\mathrm{H}$ & $\mathrm{H}$ & $\mathrm{OAC}$ & $\beta-\mathrm{OH}$ & $\beta-\mathrm{OCH}_{3}$ & $\mathrm{CH}_{2} \mathrm{CH}_{3}$ \\
\hline
\end{tabular}




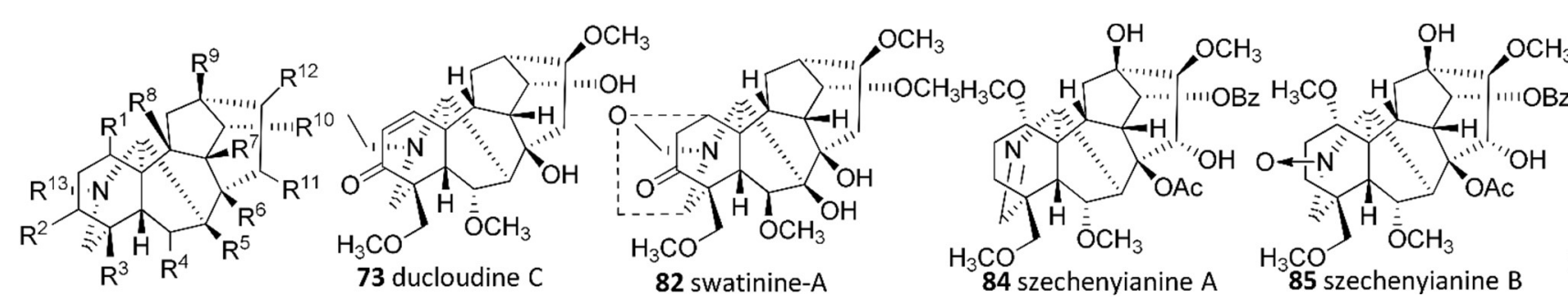

\begin{tabular}{|c|c|c|c|c|c|c|c|c|c|c|c|c|c|c|}
\hline & Compound & $\mathbf{R}^{1}$ & $\mathbf{R}^{2}$ & $\mathbf{R}^{3}$ & $\mathbf{R}^{4}$ & $\mathbf{R}^{5}$ & $\mathbf{R}^{6}$ & $\mathrm{R}^{7}$ & $\mathbf{R}^{8}$ & $\mathbf{R}^{9}$ & $\mathbf{R}^{10}$ & $\mathbf{R}^{11}$ & $\mathbf{R}^{12}$ & $\mathbf{R}^{13}$ \\
\hline 80 & sinchiangensine A & $\alpha-\mathrm{OCH}_{3}$ & $\mathrm{OH}$ & $\mathrm{CH}_{2} \mathrm{OCH}_{3}$ & $\alpha-\mathrm{OCH}_{3}$ & H & OFA1 & $\mathrm{H}$ & $\mathrm{OH}$ & $\mathrm{OH}$ & $\mathrm{OBz}$ & $\alpha-\mathrm{OH}$ & $\beta-\mathrm{OCH}_{3}$ & $\mathrm{CH}_{2} \mathrm{CH}_{3}$ \\
\hline 81 & stapfianine A & $\alpha-\mathrm{OH}$ & $\mathrm{H}$ & $\mathrm{CH}_{2} \mathrm{OCH}_{3}$ & $\mathrm{H}$ & $\mathrm{H}$ & $\mathrm{OH}$ & $\mathrm{H}$ & $\mathrm{H}$ & $\mathrm{H}$ & OSt & $\mathrm{H}$ & $\mathrm{B}-\mathrm{OCH}_{3}$ & $\mathrm{CH}_{2} \mathrm{CH}_{3}$ \\
\hline 83 & swatinine-B & $\alpha-\mathrm{OCH}_{3}$ & H & $\mathrm{CH}_{2} \mathrm{ABz}$ & $\beta-\mathrm{OCH}_{3}$ & $\beta-\mathrm{OH}$ & $\mathrm{OH}$ & $\mathrm{H}$ & $\mathrm{H}$ & $\mathrm{H}$ & $\mathrm{OCH}_{3}$ & $\mathrm{H}$ & $\beta-\mathrm{OCH}_{3}$ & $\mathrm{CH}_{2} \mathrm{CH}_{3}$ \\
\hline 87 & taipeinine $\mathrm{A}$ & $\alpha-\mathrm{OCH}_{3}$ & H & $\mathrm{CH}_{2} \mathrm{OCH}_{3}$ & $\alpha-\mathrm{OCH}_{3}$ & $\mathrm{H}$ & $\mathrm{OH}$ & $\mathrm{H}$ & $\mathrm{H}$ & $\mathrm{H}$ & $\mathrm{OH}$ & $\mathrm{H}$ & $\alpha-\mathrm{OCH}_{3}$ & $\mathrm{CH}_{2} \mathrm{CH}_{3}$ \\
\hline 88 & taipeinine $B$ & $\alpha-\mathrm{OCH}_{3}$ & H & $\mathrm{CH}_{2} \mathrm{OCH}_{3}$ & $\alpha-\mathrm{OCH}_{3}$ & H & $\mathrm{OH}$ & H & H & H & $\mathrm{OH}$ & $\mathrm{H}$ & $\beta-\mathrm{OCH}_{3}$ & $\mathrm{CH}_{2} \mathrm{CH}_{3}$ \\
\hline 89 & taipeinine $\mathrm{C}$ & $\alpha-\mathrm{OH}$ & H & $\mathrm{CH}_{2} \mathrm{OCH}_{3}$ & $\alpha-\mathrm{OCH}_{3}$ & H & $\mathrm{OH}$ & $\mathrm{H}$ & $\mathrm{H}$ & $\mathrm{H}$ & $\mathrm{OH}$ & $\mathrm{H}$ & $\alpha-\mathrm{OCH}_{3}$ & $\mathrm{CH}_{2} \mathrm{CH}_{3}$ \\
\hline 93 & vilmorine D & $\alpha-\mathrm{OCH}_{3}$ & H & $\mathrm{H}$ & H & $\mathrm{H}$ & $\mathrm{OH}$ & $\mathrm{H}$ & $\mathrm{H}$ & $\mathrm{H}$ & $\mathrm{OVr}$ & $\mathrm{H}$ & $\mathrm{B}-\mathrm{OCH}_{3}$ & $\mathrm{CH}_{2} \mathrm{CH}_{3}$ \\
\hline 96 & vilmotenitine $\mathrm{C}$ & $=0$ & $\mathrm{H}$ & $\mathrm{CH}_{3}$ & $\mathrm{H}$ & H & $\mathrm{OH}$ & $\mathrm{H}$ & $\mathrm{H}$ & $\mathrm{H}$ & $\mathrm{OH}$ & H & $\beta-\mathrm{OCH}_{3}$ & $\mathrm{CH}_{2} \mathrm{CH}_{3}$ \\
\hline 113 & mesaconitine & $\alpha-\mathrm{OCH}_{3}$ & $\alpha-\mathrm{OH}$ & $\mathrm{CH}_{2} \mathrm{OCH}_{3}$ & $\alpha-\mathrm{OCH}_{3}$ & H & OAC & H & $\mathrm{H}$ & $\mathrm{OH}$ & $\mathrm{OBz}$ & $\alpha-\mathrm{OH}$ & $\beta-\mathrm{OCH}_{3}$ & $\mathrm{CH}_{3}$ \\
\hline 114 & hypaconitine & $\alpha-\mathrm{OCH}_{3}$ & $\mathrm{H}$ & $\mathrm{CH}_{2} \mathrm{OCH}_{3}$ & $\alpha-\mathrm{OCH}_{3}$ & H & OAC & $\mathrm{H}$ & $\mathrm{H}$ & $\mathrm{OH}$ & $\mathrm{OBz}$ & $\alpha-\mathrm{OH}$ & $\beta-\mathrm{OCH}_{3}$ & $\mathrm{CH}_{3}$ \\
\hline 115 & 14-benzoyltalatisamine & $\alpha-\mathrm{OCH}_{3}$ & H & $\mathrm{CH}_{2} \mathrm{OCH}_{3}$ & $\mathrm{H}$ & H & $\mathrm{OH}$ & H & $\mathrm{H}$ & $\mathrm{H}$ & $\mathrm{OBz}$ & $\mathrm{H}$ & $\mathrm{B}-\mathrm{OCH}_{3}$ & $\mathrm{CH}_{2} \mathrm{CH}_{3}$ \\
\hline 116 & lappaconitine & $\alpha-\mathrm{OCH}_{3}$ & H & Ant & H & $\mathrm{H}$ & $\mathrm{OH}$ & $\mathrm{OH}$ & $\mathrm{H}$ & $\mathrm{H}$ & $\mathrm{OCH}_{3}$ & $\mathrm{H}$ & $\mathrm{B}-\mathrm{OCH}_{3}$ & $\mathrm{CH}_{2} \mathrm{CH}_{3}$ \\
\hline 117 & cammaconine & $\alpha-\mathrm{OCH}_{3}$ & $\mathrm{H}$ & $\mathrm{CH}_{2} \mathrm{OH}$ & $\mathrm{H}$ & $\mathrm{H}$ & $\mathrm{OH}$ & $\mathrm{H}$ & $\mathrm{H}$ & $\mathrm{H}$ & $\mathrm{OH}$ & $\mathrm{H}$ & $\mathrm{B}-\mathrm{OCH}_{3}$ & $\mathrm{CH}_{2} \mathrm{CH}_{3}$ \\
\hline 118 & columbianine & $\alpha-\mathrm{OH}$ & H & $\mathrm{CH}_{2} \mathrm{OH}$ & $\mathrm{H}$ & $\mathrm{H}$ & $\mathrm{OH}$ & $\mathrm{H}$ & $\mathrm{H}$ & $\mathrm{H}$ & $\mathrm{OH}$ & $\mathrm{H}$ & $\mathrm{B}-\mathrm{OCH}_{3}$ & $\mathrm{CH}_{2} \mathrm{CH}_{3}$ \\
\hline 119 & 1-O-demethylswatinine & $\alpha-\mathrm{OH}$ & $\mathrm{H}$ & $\mathrm{CH}_{2} \mathrm{OH}$ & $\beta-\mathrm{OCH}_{3}$ & $\beta-\mathrm{OH}$ & $\mathrm{OH}$ & $\mathrm{H}$ & $\mathrm{OH}$ & $\mathrm{H}$ & $\mathrm{OCH}_{3}$ & $\mathrm{H}$ & $\beta-\mathrm{OCH}_{3}$ & $\mathrm{CH}_{2} \mathrm{CH}_{3}$ \\
\hline
\end{tabular}

Ac:<smiles>CC(=O)Nc1ccccc1C(=O)OCCCCCCCCC(=O)c1ccccc1</smiles>

FA1: OCO- $\left(\mathrm{CH}_{2}\right)_{7}-\mathrm{CH}=\mathrm{CH}-\mathrm{CH}_{2}-\mathrm{CH}=\mathrm{CH}-\left(\mathrm{CH}_{2}\right)_{4}-\mathrm{CH}_{3}$

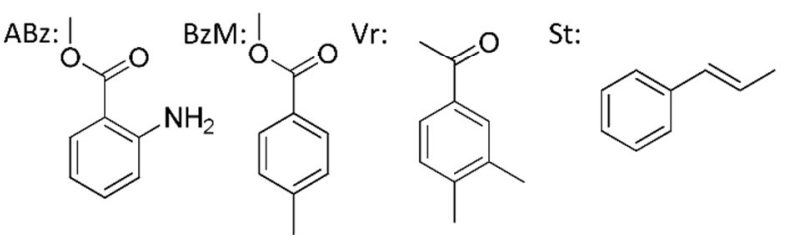

MA:

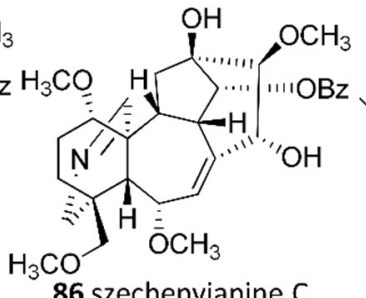

86 szechenyianine $\mathrm{C}$

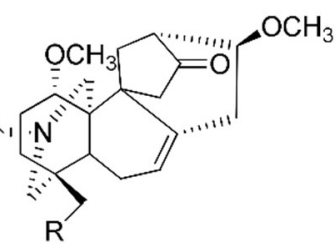

90 vilmorine $\mathrm{A}\left(\mathrm{R}=\mathrm{CH}_{3}\right)$

95 vilmotenitine $\mathrm{B}\left(\mathrm{R}=\mathrm{OCH}_{3}\right)$

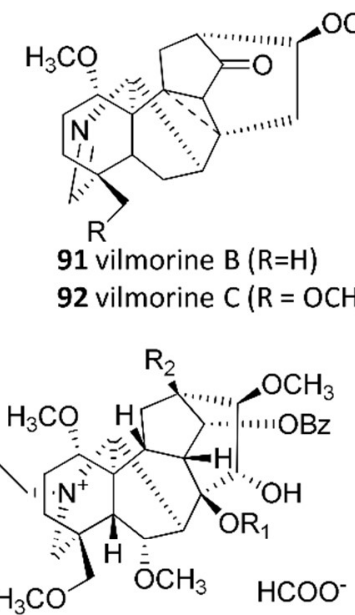

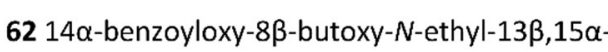
dihydroxy-1 $\alpha, 6 \alpha, 16 \beta$-18-tetramethoxyaconitane formate $\left(\mathrm{R}_{1}=\mathrm{C}_{4} \mathrm{H}_{10}, \mathrm{R}_{2}=\mathrm{OH}\right)$

$6414 \alpha$-benzoyloxy- $N$-ethyl-15 $\alpha$-hydroxy$1 \alpha, 6 \alpha, 8 \beta, 16 \beta, 18$-pentamethoxyaconitane formate $\left(\mathrm{R}_{1}=\mathrm{CH}_{3}, \mathrm{R}_{2}=\mathrm{OH}\right)$ 


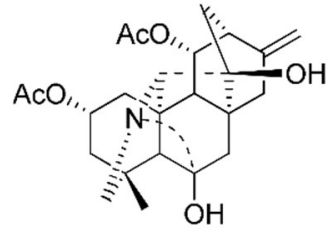

79 nagaconitine $D$

97 1,11-diacetoxy-2,13-d isobutanoyloxy

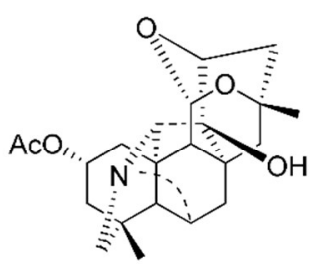

102 Guan-Fu base J

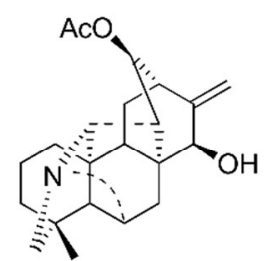

101 carmichaeline A

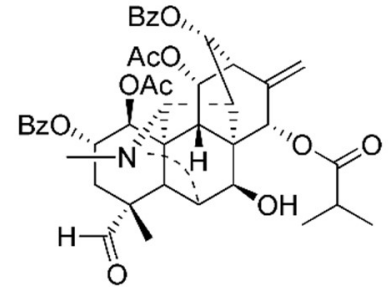

dibenzoyloxy-7-hydroxy-15-

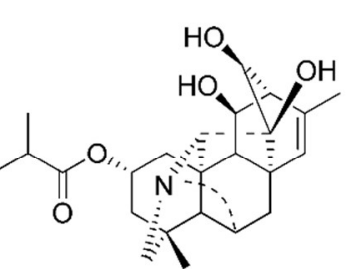

103 Guan-Fu base N

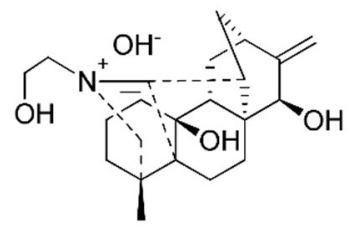

98 aconicarmicharcutinium $A$ hydroxide

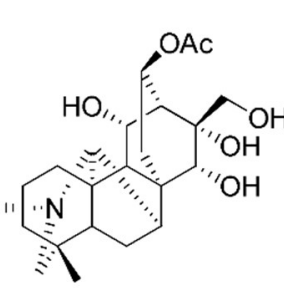

99 bullatine $\mathrm{H}$

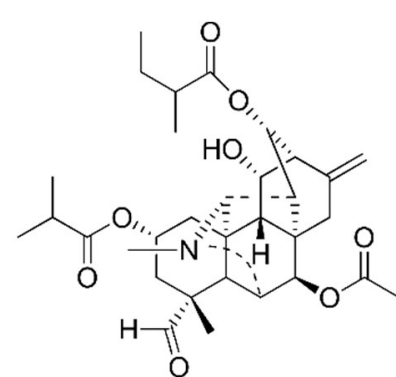

100 carmichaedine

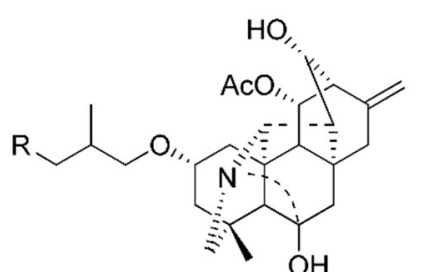

108 trichocarpisine $B\left(R=\mathrm{CH}_{3}\right)$ 109 trichocarpisine $\mathrm{C}(\mathrm{R}=\mathrm{H})$

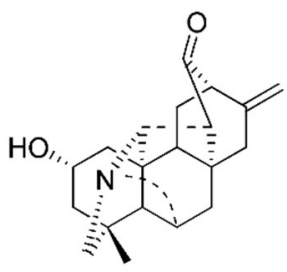

110 vilmorrianine $E$

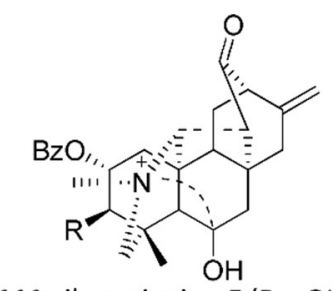

112 vilmorrianine $G(R=H)$

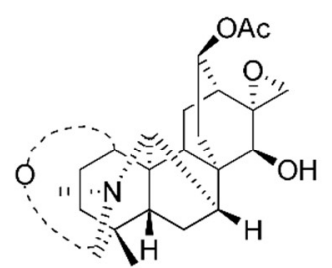

104 pubesine

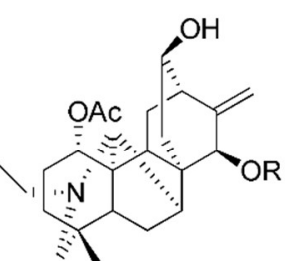

105 sinomontanidine $A(R=A c)$ 106 sinomontanidine $B(R=H)$

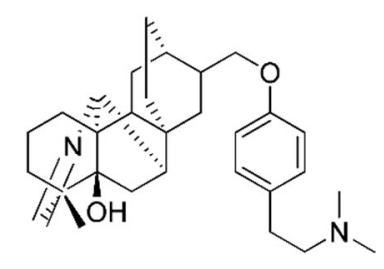

107 trichocarpisine $\mathrm{A}$

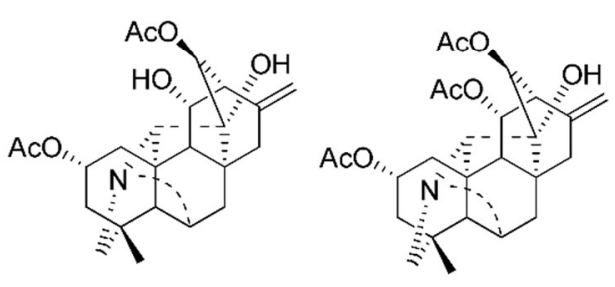

120 Guan-Fu base A (acehytisine)

121 Guan-Fu base G 


\section{B) $C_{20}$ diterpene alkaloids reported from Spiraea species}

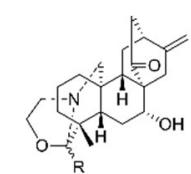

spiramine $Z-2(\mathbf{1 2 2})(R=\alpha-H)$ spiramine $Z-3(123)(R=\beta-H)$

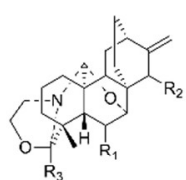

$\begin{array}{ccc}\mathbf{R}_{\mathbf{1}} & \mathbf{R}_{\mathbf{2}} & \mathbf{R}_{\mathbf{3}} \\ \beta-\mathrm{OAC} & \mathrm{H} & \mathrm{H} \\ \beta-\mathrm{OH} & \mathrm{H} & \mathrm{H} \\ \mathrm{H} & \alpha-\mathrm{OAC} & \beta-\mathrm{H} \\ \mathrm{H} & \alpha-\mathrm{OAC} & \alpha-\mathrm{H} \\ \mathrm{H} & \alpha-\mathrm{OH} & \beta-\mathrm{H} \\ \mathrm{H} & \alpha-\mathrm{OH} & \alpha-\mathrm{H}\end{array}$

spiramine $P(138)$ spiramine $Q(139)$ spiramine $\mathrm{T}(\mathbf{1 4 0})$ spiramine $U(141)$ spiramine $W(142)$

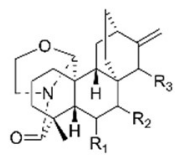

deacetylspiramine S(124) spiramide (125)

spiramine $S(126)$

spiramine $\mathrm{V}(\mathbf{1 2 7})$

$\begin{array}{ccc}\mathbf{R}_{1} & \mathbf{R}_{2} & \mathbf{R}_{\mathbf{3}} \\ \mathrm{H} & \alpha-\mathrm{OH} & \alpha-\mathrm{OH} \\ \beta-\mathrm{OAC} & \alpha-\mathrm{OAC} & \mathrm{H} \\ \mathrm{H} & \alpha-\mathrm{OH} & \beta-\mathrm{AC} \\ \mathrm{H} & \alpha-\mathrm{OH}, \mathrm{Ac} & \alpha-\mathrm{OH}\end{array}$

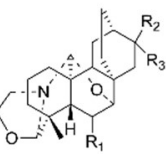

$\mathbf{R}_{1}$ $\stackrel{\mathbf{R}_{1}}{\mathrm{O}} \quad \mathbf{R}_{\mathbf{2}}$ $B-\mathrm{OH} \quad \beta-\mathrm{Me}$ $\alpha-\mathrm{OH}$ $\alpha-\mathrm{OH}$ $\beta-\mathrm{OAc} \quad \alpha-\mathrm{Me} \quad \beta-\mathrm{OH}$

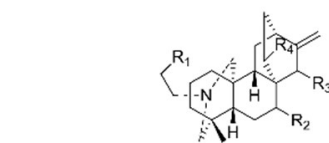

$\begin{array}{lcccc} & \mathbf{R}_{1} & \mathbf{R}_{2} & \mathbf{R}_{3} & \mathbf{R}_{4} \\ \text { spiramine G (128) } & \mathrm{OH} & \alpha-\mathrm{OH} & \mathbf{H} & =\mathrm{O} \\ \text { spiramine H(129) } & \mathrm{OH} & \mathrm{H} & \alpha-\mathrm{OH} & =0 \\ \text { spiramine I (130) } & \mathrm{OH} & \mathrm{H} & \alpha-\mathrm{OAC} & =0 \\ \text { spiratine A (131) } & =\mathrm{O} & \alpha-\mathrm{OH} & \alpha-\mathrm{OH} & \mathrm{H}\end{array}$

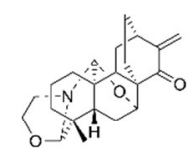

spiramine N-6 (152)

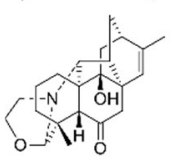

spirasine I (157)

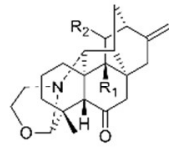

$\begin{array}{lccc} & \mathbf{R}_{\mathbf{1}} & \mathbf{R}_{\mathbf{2}} & \\ \text { spiradine D (153) } & \mathrm{H} & \mathrm{H} & \\ \text { spirasine II (154) } & \beta-O H & H & \\ \text { spirasine III (155) } & \beta-\mathrm{OH} & =\mathrm{O} & \\ \text { spiredine (156) } & \mathrm{H} & =\mathrm{O} & \text { spirasine V (158) }\end{array}$

spirasine V $(158)$

spirasine VII (160) spirasine VIII (161)

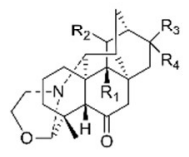

$\mathbf{R}_{1}$
$\mathrm{H}$
$\mathrm{H}$
$\mathrm{\beta}-\mathrm{OH}$
$\mathrm{B}-\mathrm{OH}$

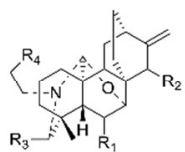

$\begin{array}{llll}\mathbf{R}_{\mathbf{1}} & \mathbf{R}_{\mathbf{2}} & \mathbf{R}_{\mathbf{3}} & \mathbf{R}_{\mathbf{4}} \\ \mathrm{H} & \mathrm{H} & & \end{array}$ deacetylspiramine $\mathrm{F}$ (143) $\mathrm{H} \quad \mathrm{OH} \quad \mathrm{H} \quad \mathrm{OH}$ spiraeaine $A(144) \quad \beta-O H \quad H \quad H \quad O H$ p spiramilactam $A($ (145) $\quad \beta-O H \quad H=O \quad O H$ $\alpha-\mathrm{H}$ spiramilactam $B(146) \quad \alpha-\mathrm{OH} \quad \mathrm{H} \quad=\mathrm{O} \quad \mathrm{OH}$ $\alpha-H$ spiramine $E(147) \quad H \quad \alpha-O A C \quad H \quad O A C$ $\alpha-\mathrm{H}$ spiramine $\mathrm{F}(\mathbf{1 4 8}) \quad \mathrm{H} \quad \alpha-\mathrm{OAc} \quad \mathrm{H} \quad \mathrm{OH}$ $\alpha-H$ spiramine $\mathrm{R}(149) \quad \mathrm{H} \quad \alpha-\mathrm{OAC}=\mathrm{O} \quad \mathrm{OH}$ $\beta-H$ spiramine $X(150) \quad B-O A C \quad H=O \quad O A C$ spiramine $Y(151)$

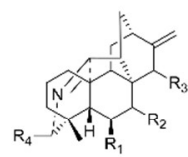

19-O-deethylspiramine $\mathrm{N}(164)$

spiramine J (165)

spiramine K (166)

spiramine $L$ (167)

spiramine $M(168)$

spiramine $N(\mathbf{1 6 9})$

spiramine $O(170)$

spiramine $Z$ (171)

spiratine $B(172)$
$\begin{array}{lll}\mathbf{R}_{1} & \mathbf{R}_{\mathbf{2}} & \mathbf{R}_{\mathbf{3}}\end{array}$

H $\quad \alpha-\mathrm{OH} \quad \alpha-\mathrm{OH}$

$\mathrm{H} \quad \alpha-\mathrm{OH} \quad \alpha-\mathrm{OH}$

$\mathrm{H} \quad \alpha-\mathrm{OH} \quad \alpha-\mathrm{OH}$

$\mathrm{H} \alpha-\mathrm{OH} \quad \alpha-\mathrm{OAC}$

$\mathrm{H} \alpha$-OAc $\alpha-\mathrm{OH}$

$\mathrm{H} \quad \alpha-\mathrm{OH} \quad \alpha-\mathrm{OH}$

$\mathrm{H} \quad \alpha-\mathrm{OH} \quad \alpha-\mathrm{OH}$

$\beta-O A C \quad \alpha-O A C \quad H$

$\beta$-OAC $\alpha$-OAC $\quad H$

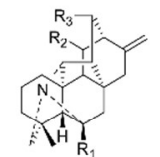

$\mathbf{R}_{\mathbf{4}}$

$\beta$ - $\mathrm{OH}$ spiradine $A(173) \quad \begin{array}{cc}\mathbf{R}_{1} & \mathbf{R}_{2} \\ \beta-O H & =0\end{array}$

$\alpha-\mathrm{CH}_{2}-\mathrm{Ac}$ spiradine $\mathrm{B}(\mathbf{1 7 4}) \quad \beta-\mathrm{OH} \quad \mathrm{OH}$

$\beta-\mathrm{CH}_{2}-\mathrm{AC}$ spiradine $\mathrm{C}(175) \quad \mathrm{B}-\mathrm{OH} \quad \mathrm{OAC}$

$\alpha-\mathrm{CH}_{2}-\mathrm{AC}$ spirasine IV (176)

$\mathrm{B}-\mathrm{CH}_{2}-\mathrm{A}$

$\beta$-OEt

$\beta$-OMe

OEt

$\mathrm{OH}$

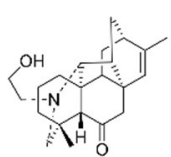

$\mathbf{R}_{4}$ $\alpha-\mathrm{OH}$ $\alpha-\mathrm{OH}$

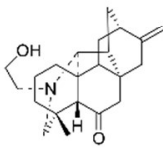

spirafine III (163)

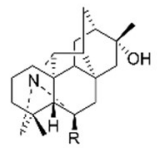

spiraqine (193) $(\mathrm{R}=\mathrm{H})$ 6-hydroxyspiraquine (194) $(\mathrm{R}=\mathrm{OH})$

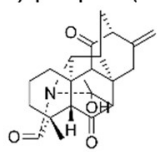

spirein (195) 
<smiles>C=C1C(=O)OC2CC(C)C3CC(O)C(O)[C@@]3(C)CC12</smiles>

cumanin (196)

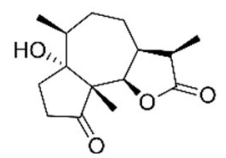

dihydrocoronopilin (201)

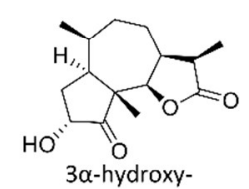

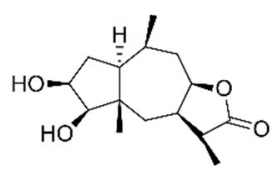

dihydrocumanin (197)

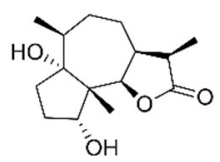

tetrahydrocoronopilin (202)

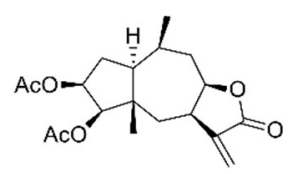

cumanin diacetate (198)

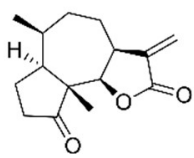

damsin (203)

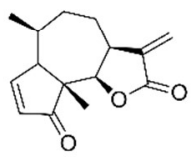

ambrosin (208)<smiles></smiles>

isopaulitin (213)

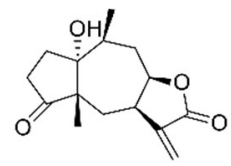

peruvin (199)

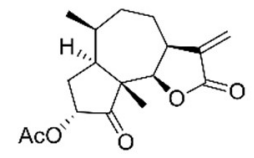

$3 \alpha$-acetoxydamsin $(204)$<smiles>C[C@H]1CCC2C(OC(=O)[C@H]2C)[C@@]2(C)C(=O)C=CC12</smiles>

artesovin (209)<smiles>C=C1C(=O)O[C@H]2C1CC[C@@H](C)[C@@]1(C)CC(=O)O[C@H]21</smiles>

psilostachyin A (214)

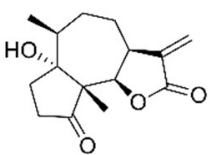

coronopilin (200)

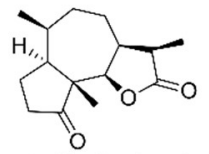

11 $\alpha \mathrm{H}, 13$-dihydrodamsin (205)

$11 \alpha \mathrm{H}, 13$-dihydrodam $\sin (206) 11 \alpha \mathrm{H}, 13-$ dihydrodamsin (207)
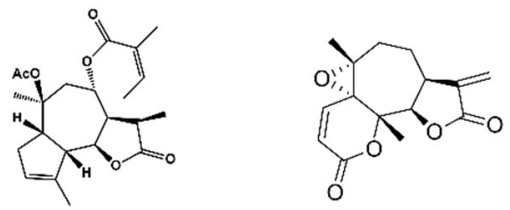

paulitin (212)

10-acetoxyguai-3-en-6,12-olide (211)<smiles>C=C1C(=O)O[C@H]2[C@@H]1CC[C@@H](C)[C@@H]1CCC(=O)O[C@]12C</smiles>

psilostachyin C (216)<smiles>C=C1CCC[C@]2(C)C[C@H]3OC(=O)C(=C)[C@H]3C[C@H]12</smiles>

isoalantolactone (221)

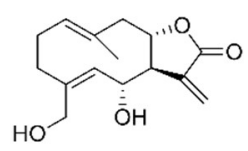

artemisiifolin (217)<smiles>C=C1CCC[C@]2(C)C[C@H]3OC(=O)C(C)[C@H]3C[C@H]12</smiles>
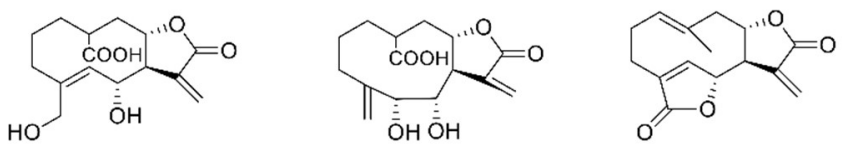
artemisiifolinic acid (218) isoartemisiifolinic acid (219) isabelin (220)<smiles>CC1CCC2C(C)C(=O)OC2[C@](C)(C=O)C1CCC(=O)O</smiles>

3,4-seco-ambrosanolide (210)

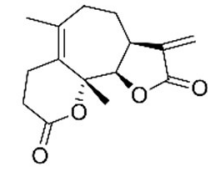

psilostachyin B (215)

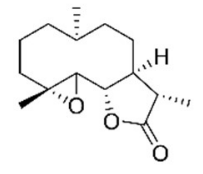

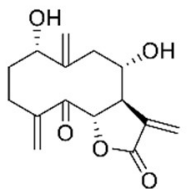

dihydroisoalantolactone (222)

11ß,13-dihydroparthenolide (223) 5-oxo-8 $\alpha$-hydroxy-1-epiartemorin (224) 


\section{APPENDIX II.}

\section{Publications related to the thesis:}

I. Kiss T; Orvos P; Bánsághi Sz; Forgó P; Jedlinszki N; Tálosi L; Hohmann J; Csupor D. Identification of diterpene alkaloids from Aconitum napellus subsp. firmum and GIRK channel activities of some Aconitum alkaloids FITOTERAPIA 2013; 90: 85-93. doi: 10.1016/j.fitote.2013.07.010

II. Kiss T; Szabó A; Oszánci G; Lukács A; Tímár Z; Tiszlavicz L; Csupor D. Repeated-dose toxicity of common ragweed on rats PLOS ONE 2017; 12: e0176818 (18p) doi: 10.1371/journal.pone.0176818

III. Kiss T; Borcsa B; Orvos P; Tálosi L; Hohmann J; Csupor D.

Diterpene lipo-alkaloids with selective activities on cardiac $\mathrm{K}^{+}$channels PLANTA MEDICA 2017; accepted doi: $10.1055 / s-0043-109556$

IV. $\quad$ Kiss T; Mácsai L; Csupor D; Datki Zs.

In vivo screening of diterpene alkaloids using bdelloid rotifer assays Acta Biologica Hungarica 2017; 68 (4): accepted

V. Kiss T; Cank K; Orbán-Gyapai O; Liktor-Busa E; Rutkovska S; Zomborszki Z; Pučka I; Németh A; Csupor D.

Phytochemical and pharmacological investigation of Spiraea chamaedryfolia-A contribution to the chemotaxonomy of Spiraea genus BMC Research Notes 2017; submitted 